فاعلية برنامج ارشادي منبثق من دراسة الوعي واتباع التدابير الوقائية أثناء جائحة كورونا لاى عينة من العاملين بجامعة الإسكندرية

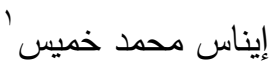

- أوضحت نتائج الدراسة أن الإناث وأفراد العينة من المتزوجين

ولايهم أبناء كانوا أكثر وعياً بالتدابير الوقائية.

- - مجود علاقة ارتباطية معنوية بين كل من التزام أفراد العينة

باتباع التدابير الوقائية ووعيهم بهذه التدابير.

- - أوضحت النتائج البحثية أن الأفراد الحاصلين على تعليم

جامعي وممن يشغلون وظائف مهنية يتمتعون بوعي والتزام

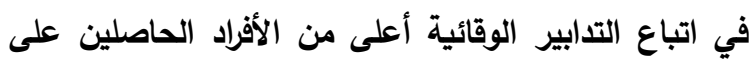
مؤهلات تعليمية أقل ويشغلون وظائف ادارية أو حرفية.

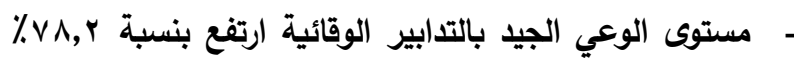

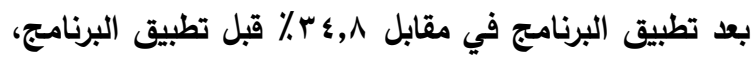
كما أوضحت النتائج أن الغالبية العظى من من أفراد العينة

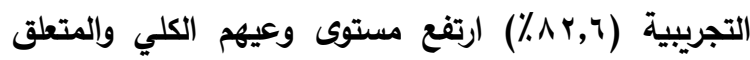
بأسباب انتشار وأعراض الإصابة بالفيروس والتدابير الوقائية

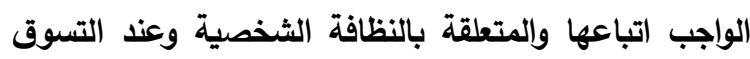

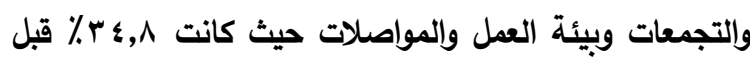
تطبيق البرنامج ، كما ارتفع معدل الوعي الجيا بضرورة

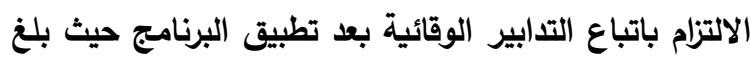

$$
\% \vee \wedge, r
$$

- وجود فروق دالة احصائياً بين التطبيق القبلي والبعدي في الوعي والالتزام باتباع التابير الوقائية عند مستوى احتمالي ..,.

الكلمات المفتاحية:- برنامج ارشادي- التدابير الوقائيةجائحة كورونا.

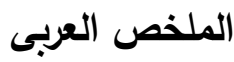

أُجري هذا البحث بهدف بناء وتنفيذ وتقييم برنامج ارشادي يهرف إلى تحسين الوعي واستمرار اتباع التدابير الوقائية اثناء

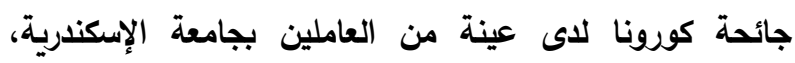
وأستخدم الاستبيان بالمقابلة الثخصية لجمع البيانات المتعلقة

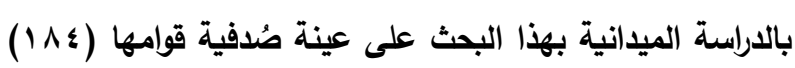
مبحوث ومبحوثة من العاملين بجامعة الإسكندرية لتحديد

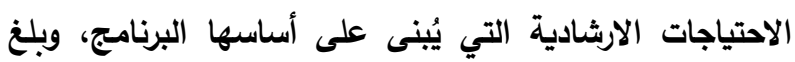

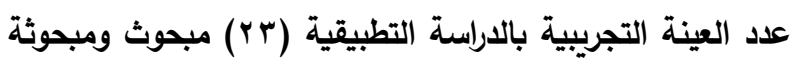
من العاملين بكلية الزراعة- جامعة الإسكندرية، ثم تم تفريغ بالئ وتحليل البيانات احصائياً باستخدام برنامج الحزمة الاحصائية للعلوم الاجتماعية (SPSSV23) واجراء المعاملات الاحصائية التالية: النسب المئوية، المتوسط والانحراف المعياري، اختبار "ت"، معامل ارتباط بيرسون، اختبار "ف"، معامل الاقتران، وأسفرت نتائج الدراسة عما يلي: لئي

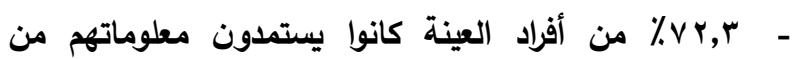

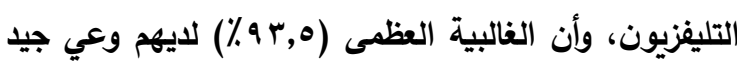
بالتدابير الوقائية الواجب اتباعها للحد من انتثار المرض المانه

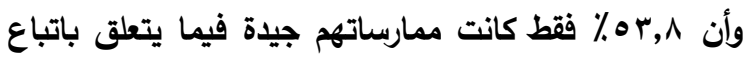
التدابير الوقائية للوقاية من الإصابة بالفيروس. -

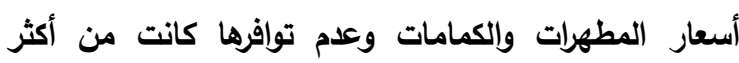

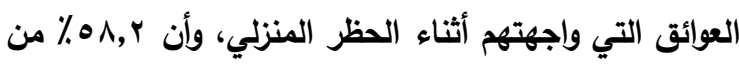

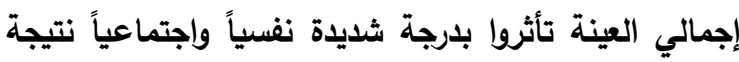
البقاء في المنزل خلال فترة العظر. 
حالة 1. . ., . . حالة (WHO, 2020). وعليه بدأت منظمة الصحة العالمية بالتعاون مع الخبراء والحكومات للإسراع في توسيع نطاق المعرفة العلمية عن فيروس كورونا المستجد ومتابعة طرق انتشاره وتحديث الإجراءات والتدابير الوقائية الواجب إتباعها للحد من انتشاره وتفشيه في المجتمعات (محمد

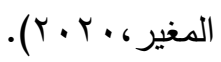

ووفقاً لأحدث إحصائيات منظمة الصحة العالمية عن فيروس كورونا المستجد على الصعيد العالمي والعربي يوم

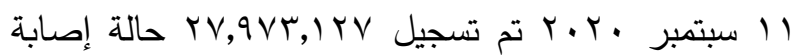

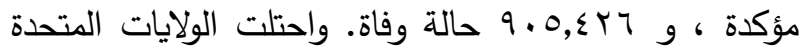
الامريكية المرتبة الأولى من حيث إجمالي الإصابات إذ بلغ

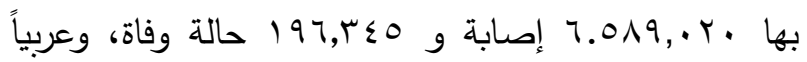
احتلت المملكة العربية السعودية المرتبة الأولى من حيث عدد

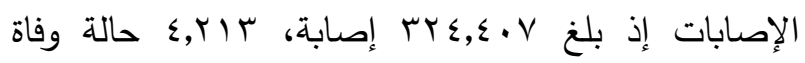

.(WHO, 2020)

بالنسبة لجمهورية مصر العربية فقد بلغ عدد الاصابات

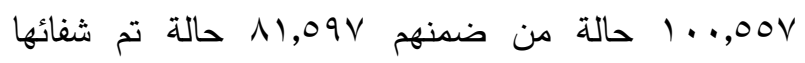

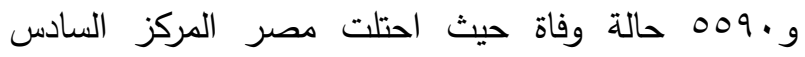
والعشرون في نسبة الوفيات من إجمالي عدد المصابين، كما احتلت المركز الحادي والثلاثون في عدد المصابين بالفيروس من بين 10 بمنطقة ودولة حول العالم (رئاسة مجلس الوزراء، $\cdot(r \cdot r$.

فيروس كورونا المستجد (كوفيد -9 1) هو ذلك الفيروس الذي ينتمي إلى فيروسات كورونا والتي تسبب المرض للإنسان والحيوان، وينتقل هذا الفيروس إلى الإنسان عن طريق الرذاذ الذي يتتاثر من الأنف أو الفم عندما يسعل أو

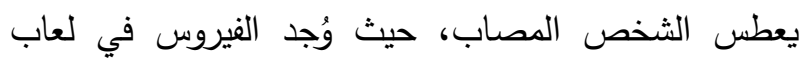
المرضى المصابين، و يرتفع مستواه في المرضى الذين يعانون من الأعراض أو قبل ظهور الأعراض ، كما يمكن أن

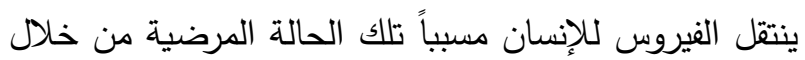

\section{المقدمة والمشكلة البحثية}

يمر العالم في القرن الماضي والحاضر بأنواع من الاوبئة ينجم عنها العديد من الاضرار التي تصيب الافراد وتودي بحياتهم، الامر الذي ينعكس بدوره على تقدم الدول باعتبار الانسان المحرك الرئيسي والمورد البشري الاساسي للتنمية الاقتصادية للمجتمعات. وعلى سبيل المثال لا الحصر فقد بـدي ظهرت حالات الانفلونزا الاسبانية عام 1919 19 19 19 والتي تسببت في ارتفاع معدلات الوفيات لأكثر من ·. مليون

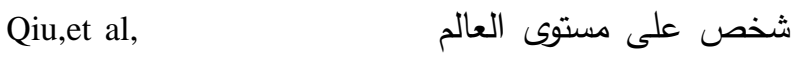
(2017)، وفي السنوات الأخيرة شهد العالم حالات تفشي حادة لفيروسات خطيرة مثل فيروس سارس عام r...r، ووباء

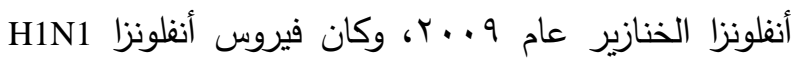
في 9 . . أول وباء أنغلونزا في القرن الحادي والعشرين وتسبب في وفاة أكثر من ل...11. شخص، ولا يعتبر المرض وباء بمجرد انتشاره أو ارتفاع نسبة الوفيات به، بل وبل ودئ يجب أن يكون أيضاً معديا، والأوبئة بطبيعتها أمراض جديدة لا يتوافر بشأنها المعلومات الكافية بكيفية انتشارها وطرق

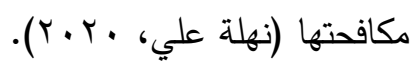
يمر العالم الآن بجائحة كورونا، وتُعرف الجائحة بأنها

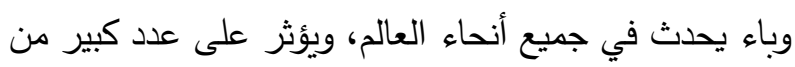
الناس. وتعتبر جائحة كورونا (كوفيد - 9 (1) هي أول جائحة عالمية مستمرة حالياً، حيث تفشى المرض للمرة الأولى في مدينة ووهان الصينية في أوائل شهر ديسمبر 9 1 • ب،

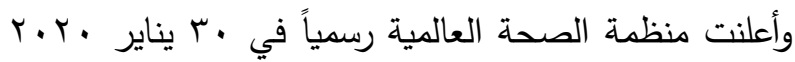
أن تفشي الفيروس يثكل حالة طوارئ صحية عامة تبعث \& Mannan, 2020) على القلق الدولي .(Farhana وأكدت المنظمة تحول الوباء إلى جائحة يوم ال إس مارس r.r.r.

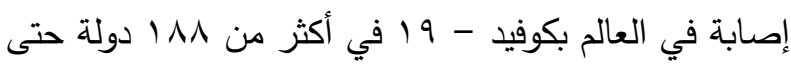

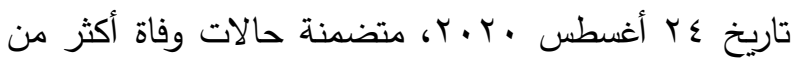


المدارس والملاعب والمسارح ومراكز التسوق ومنع السفر

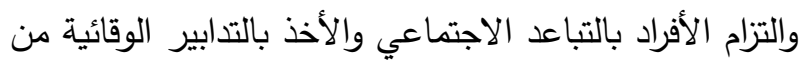

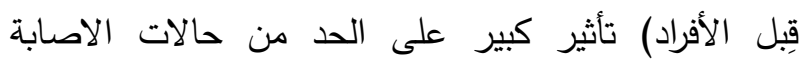

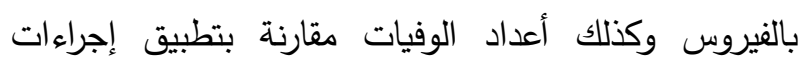

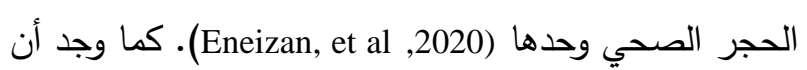

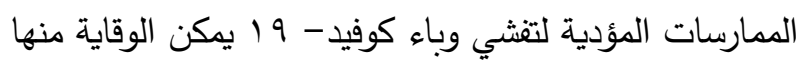

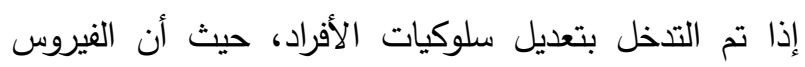

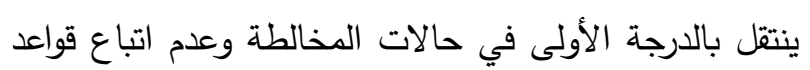
التباعد الاجتماعي بين الأفراد.

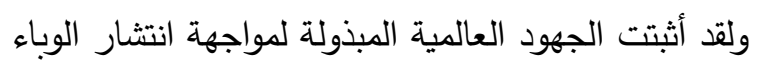

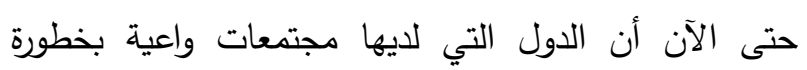

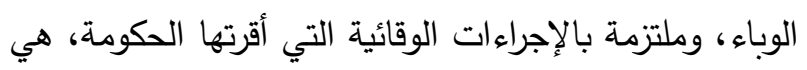

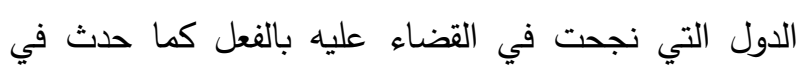
الصين، الأمر الذي دفع الباحثة إلى إجراء الدراسة كمحاولة

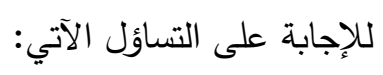

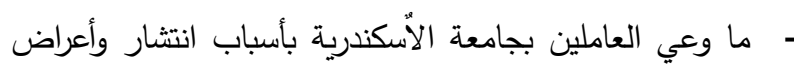

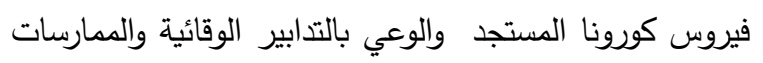

$$
\text { الواجب اتباعها للوقاية من الفيروس؟ }
$$

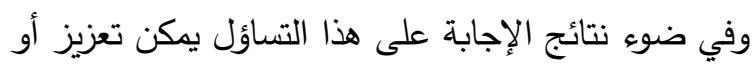

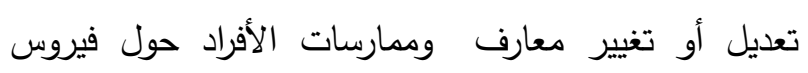

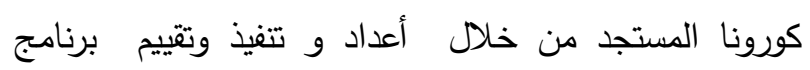

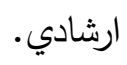

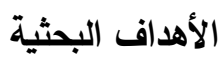

استهدفت هذه الدراسة بصفة أساسية بناء وتتفيذ وتقييم برنامج ارشادي يهدف إلى تحسين الوعي وتحسين التدابير

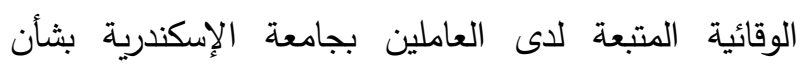

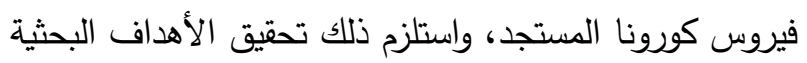

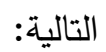
1-التعرف على بعض الخصائص الاجتماعية - الاقتصادية

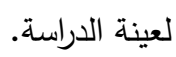

انتثار الرذاذ على الأسطح المحيطة بالثخص (WHO, 2020)، وتتزاوح فترة حضانة الفيروس ما بين يوماً واحد وء ال يوماً، وعادة ما تستمر خمسة أيام، وتتمثل

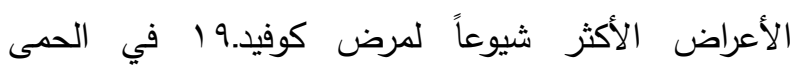

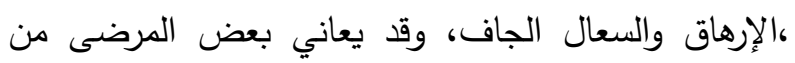

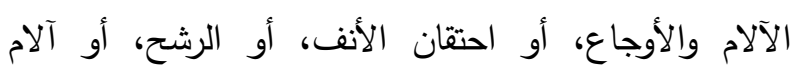

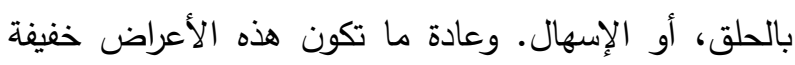

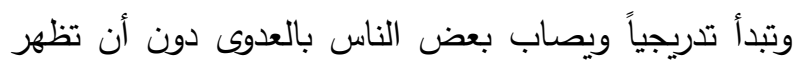

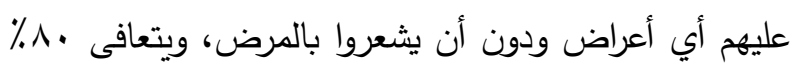
من الأشخاص من المرض دون الحاجة إلى علاج خاص، وند

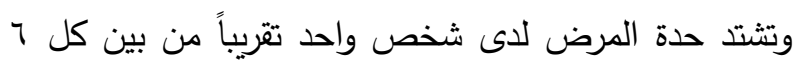

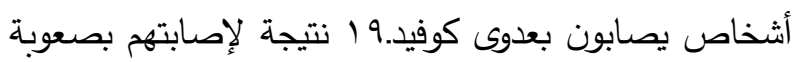

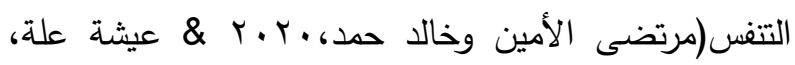
. (T. T. أظهرت التحليلات الوبائية التي أجرتها منظمة الصحة

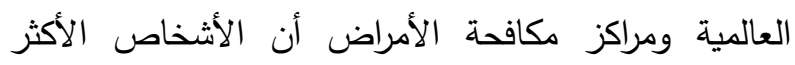

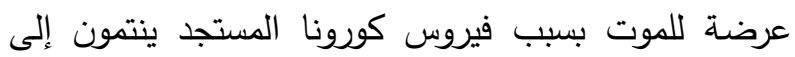

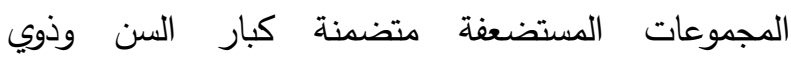

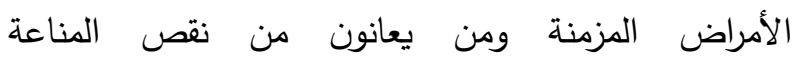
. ولقد أدت جائحة الفيروس (Abdelhafiz, et al, 2020)

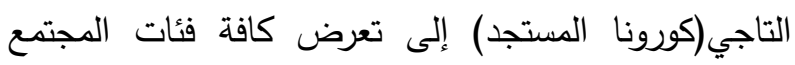

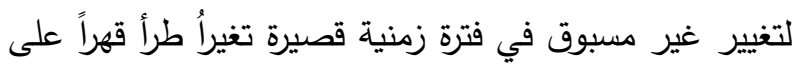

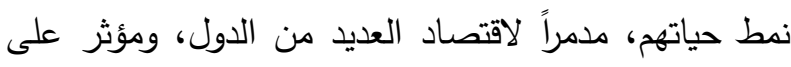
أنظمة الرعاية الصحية في جميع دول العالم ومُنع التتقلات

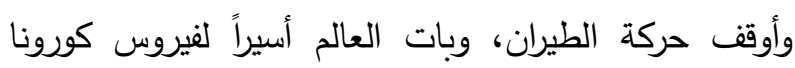

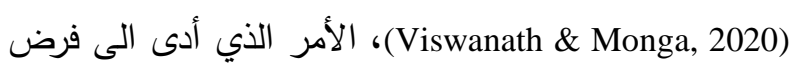

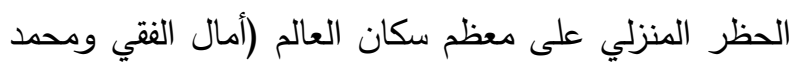
أبو الفتوح، ·.r.r) وأدى الحجر الصحي دوراً حيوياً في

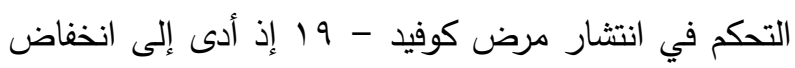

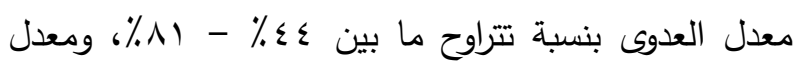

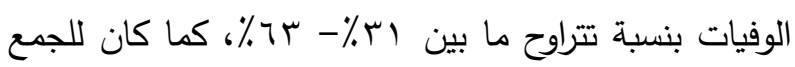

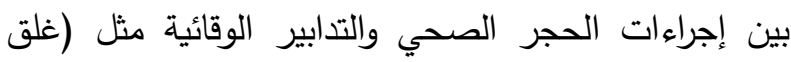


بالإضافة إلى أن حداثة هذه الجائحة وعدم إلمام الأفراد بالوعي والدراية بالتدابير الوقائية اللازمة للوقاية من الإصابة بفيروس كورونا المستجد، ونظراً لأهمية وعي الفرد ودوره

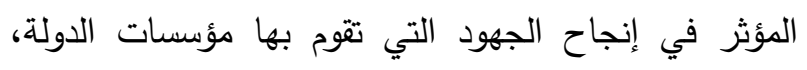
وبدون وجود وعي مجتمعي فعال فإن نسبة كبيرة من هذه الجهود يمكن أن تذهب هباءاً، فالوعي الفردي يمثل لبنه في في فئي هرم الوعي المجتمعي، فالفرد قادر على المساهمة بجهوده الفردية في إنجاح جهود التصدي لهذه الجائحة من خلال عدة تدابير واحتياطات مثل الالتزام الدقيق والصارم بالتعليمات

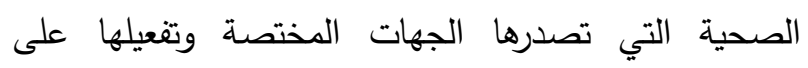
مستوى المنزل وأماكن العمل. حيث أن إدارة الأزمة تعتمد في المقام الأول على التزام الأفراد بالتدابير المتخذة والموصي بها، وتتأثر هذه التدابير إلى حد كبير بالوعي والاتجاهات والممارسات ( Abdelhafiz,et al, 2020 ). ونظراً لاجتياح فيروس كورونا المستجد للعالم وما صاحب ذلك العديد من الإجراءات الاحترازية التي اتخذتها الكثير من الدول من أجل محاصرة الفيروس ومنع انتثاره، والتي من بينها الحظر المنزلي ولما لهذه الإجراءات من تداعيات على الكثير من الأفراد.

ولقد اهتمت الباحثة أن تكون عينة الدراسة من العاملين لما لديهم الكثير من المهام والمسئوليات داخل الأسرة وخارجها في مجال العمل، والتي قد تتعاظم مع تلك الظروف التي حدثت نتيجة انتشار الجائحة، فكل فرد منهم يفكر في أسرته

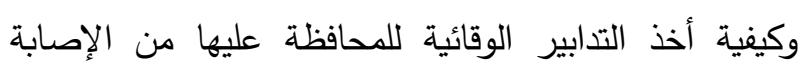
بالمرض، وفي نفس الوقت يفكر في عمله وكيفية انجازه في

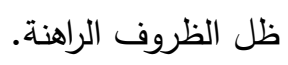

\section{فروض البحث}

ا-لا يوجد فروق معنوية بين نوع الجنس والحالة الاجتماعية

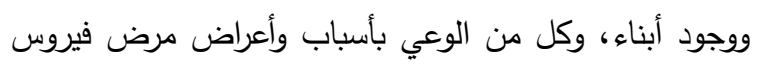

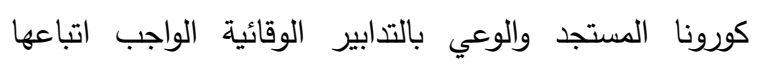

Y-التعرف على مصادر الحصول على المعلومات الخاصة بفيروس كورونا المستجد لعينة الدراسة. r-تحديد مستوى وعي عينة الدراسة والمتعلقة بأسباب انتشار فيروس كورونا المستجد، والأعراض الثائعة عند الإصابة بالفيروس. ع-تحديد مستوى وعي عينة الدراسة بالتدابير الوقائية، وممارساتهم الفعلية في اتباع هذه التدابير للحد من انتشار فيروس كورونا المستجد والوقاية من الإصابة بها، والعوائق التي تواجه الأفراد لاتباع التدابير •

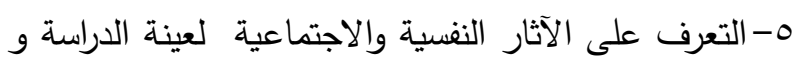
الناتجة عن البقاء بالمنزل خلال فترة الحظر المنزلي.

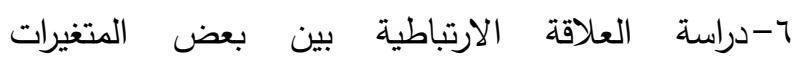

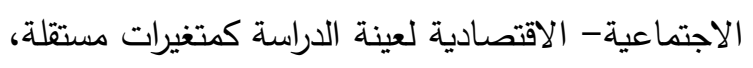
وكل من وعي عينة الدراسة بالتدابير الوقائية وممارساتهم الفعلية في اتباع هذه التدابير للوقاية من بن الاصابة بفيروس كورونا المستجد كتغيرات تابعة.

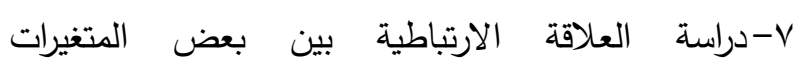

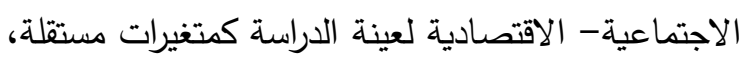
وكل من الآثار النفسية والاجتماعية الناتجة عن البقاء

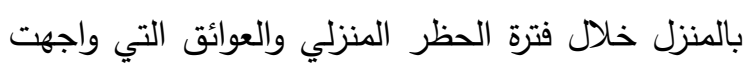
عينة الدراسة في اتباع التدابير الوقائية. ^-دراسة العلاقة الارتباطية بين وعي عينة الدراسة بالتدابير الوقائية للحد من انتشار المرض وممارستهم الفعلية في

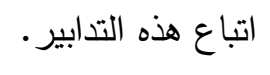
9- إعداد وتتفيذ وتقييم برنامج ارشادي منبثق من النتائج المتحصل عليها من الأهداف السابقة، يهدف إلى تتمية لئية

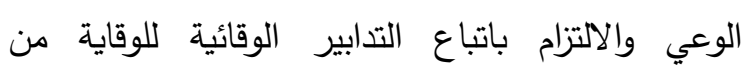

$$
\text { الإصابة بالفيروس. }
$$

\section{الأهمية البحثية}

نظرا للانتشار الكبير والمتفاقم لجائحة كورونا المستجد في الآونة الأخيرة، وحسب ما تم ذكره سابقاً من إحصائيات، 


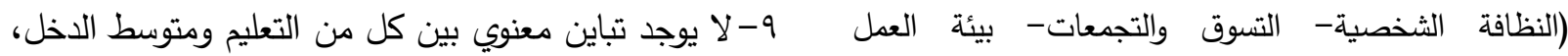

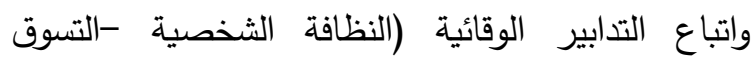

$$
\text { والتجمعات - بيئة العمل والمواصلات). }
$$

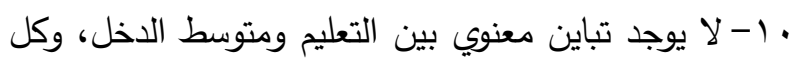

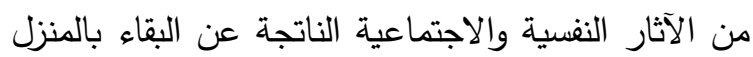
خلال فترة الحظر المنزلي والعوائق التي تواجه عينة الدراسة في اتباع التدابير الوقائية.

| ا - لا يوجد اقتران معنوي بين منطقة السكن ونوع الوظيفة، وكل من الوعي بأسباب وأعراض مرض فيروس كورونا المستجد والوعي بالتدابير الوقائية الواجب اتباعها (النظافة

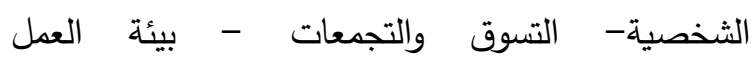
والمواصلات). r ا - لا يوجد اقتران معنوي بين كل من منطقة السكن ونوع

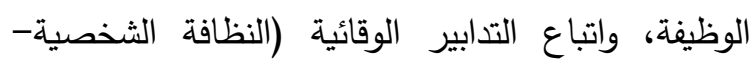
التسوق والتجمعات- بيئة العمل والمواصلات). با - لا يوجد اقتران معنوي بين منطقة السكن ونوع الوظيفة، وكل من الآثار النفسية والاجتماعية الناتجة عن البقاء بالمنزل خلال فترة الحظر المنزلي والعوائق التي تواجه عينة الدراسة في اتباع التدابير الوقائية. ع ا- لا يوجد فرق معنوي لكل من الوعي بالتدابير الوقائية

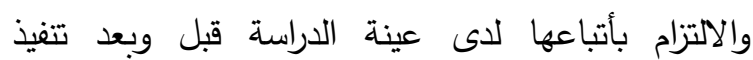

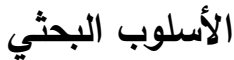

أولاً: المصطلحات العلمية والتعاريف الإجرائية: - الجائحة: انتشار الوباء في عدة بلدان أو قارات، وعادة ما يصاب به عدد كبير من السكان (حنان ملكاوي, •r. ·r). - فيروس كورونا المستجد (كوفيد- 9 - 1): فيروس مستحدث وهو سلالة جديدة من الفيروسات التاجية يصيب الجهاز التنفي للإنسان (المركز الوطني للتثقيف

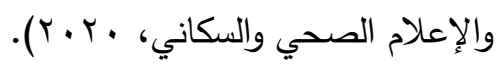

والمواصلات).

ץ-لا يوجد فروق معنوية بين كل من نوع الجنس والحالة

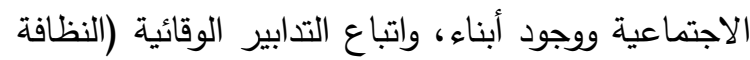

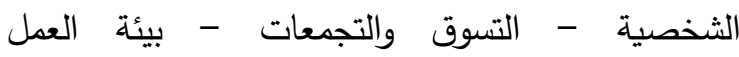
والمواصلات). ب- لا يوجد فروق معنوية بين نوع الجنس والحالة الاجتماعية

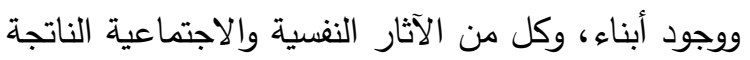
عن البقاء بالمنزل خلال فترة الحظر المنزلي والعوائق التي تواجه عينة الدراسة في اتباع التدابير الوقائية. ع- لا توجد علاقة ارتباطية معنوية بين السن وعدد سنوات العمل، وكل من الوعي بأسباب وأعراض فيروس كورونا المستجد والوعي بالتدابير الوقائية الواجب اتباعها (النظافة الثخصية - التسوق والتجمعات = بيئة العمل والمواصلات). 0- لا توجد علاقة ارتباطية معنوية بين كل من السن وعدد سنوات العمل، واتباع التدابير الوقائية (النظافة

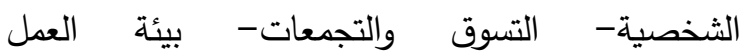
والمواصلات). ج- لا توجد علاقة ارتباطية معنوية بين السن وعدد سنوات العمل، وكل من الآثار النفسية والاجتماعية الناتجة عن البقاء بالمنزل خلال فترة الحظر المنزلي والعوائق التي تواجه عينة الدراسة في اتباع التدابير الوقائية. V-V توجد علاقة ارتباطية معنوية بين الوعي بالتدابير الوقائية وممارساتهم الفعلية في اتباع هذه التدابير • ^- لا يوجد تباين معنوي بين التعليم ومتوسط الدخل، وكل من الوعي بأسباب وأعراض مرض فير فيروس كورونا المستجد والوعي بالتدابير الوقائية الواجب اتباعها (النظافة الثخصية - التسوق والتجمعات- بيئة العمل

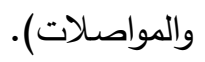




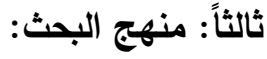

اتبع البحث منهجين أحدهما المنهج الوصفي التحليلي

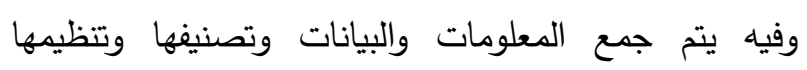

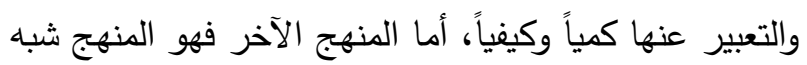

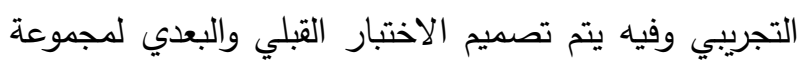

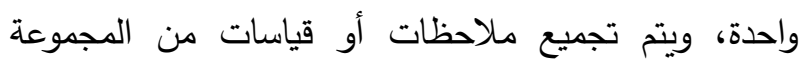

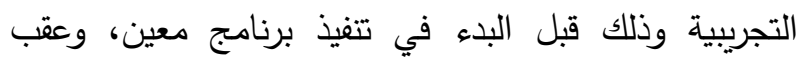

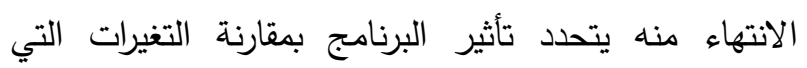

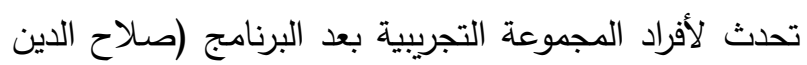

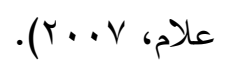

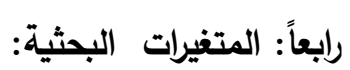
وفقاً لأهداف البحث تم تحديد مجموعة من المتغيرات البحثية وهي: - البي:

1-المتغيرات المستقلة: تمثلت في كل من نوع الجنس -

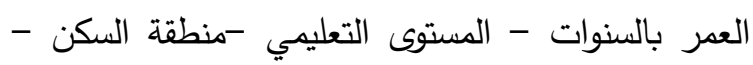

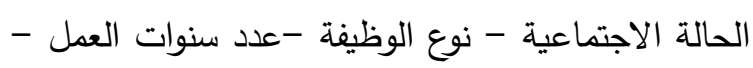
متوسط الدخل الثهري، وجود أبناء بالأسرة. ץ-المتغيرات التابعة: تمثلت في مستوى وعي عينة الدراسة

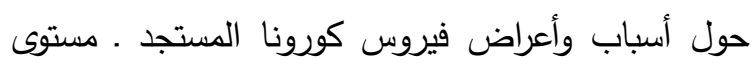

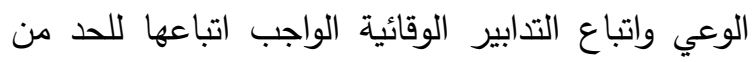

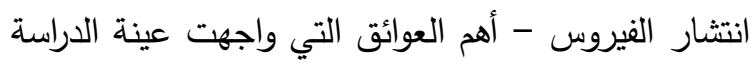

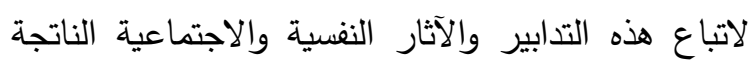
عن البقاء بالمنزل خلال فترة الحظر المنزلي. r-المتغيرات الوسيطة: مستوى وعي عينة الدراسة بالتدابير

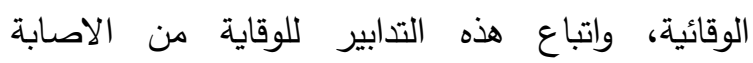
بالفيروس.

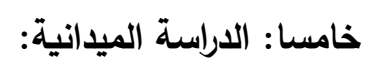
1- - - أداة جمع البيانات استخدم الاستبيان بالمقابلة الثخصية لجمع البيانات ولقد

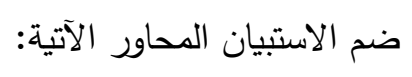

- الوعي: معرفة الأفراد بأهمية تجنب المخاطر التي تهدد صحتهم، وتقييهُ من كافة الأمراض التي تصيب الإنسان (عمران ملحم، 99 (r. (r). ويقصد به في هذه الدراسة مدى توفر المعلومات عن

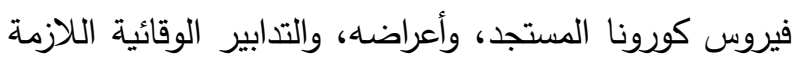
للحد من انتشار الفيروس.

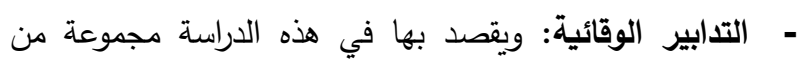

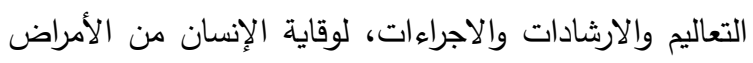

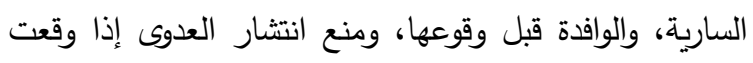
ومدى اتباع تلك التدابير. - البرنامج الارشادي: برنامج مخطط ومنظم يقوم على لإنى أسس علمية لتقديم الخدمات الارشادية، بهدف تتمية أو الو

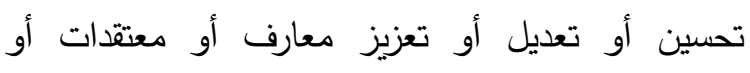
اتجاهات أو سلوك الفئة المستهدفة، من خلال مجموعة من الأنشطة والخبرات المنظمة والمخططة والمحددة

$$
\text { بجدول زمني معين (سميرة قنديل، } 7 \text { ( • ب). }
$$

والمقصود به في هذه الدراسة هو مجموعة من المعلومات

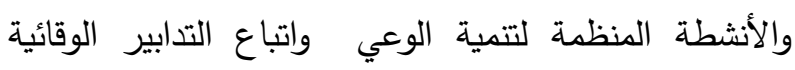

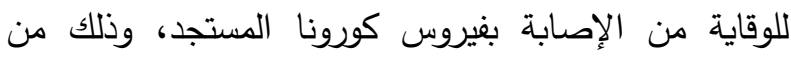
خلال وحدات تعليمية مصممة ومتضمنة مجموعة من الإنية الأهداف والأنثطة والوسائل وأساليب التدريس، مخططة

$$
\text { ومحددة بجدول زمني معين. }
$$

ثانياً: حدود الدراسة:

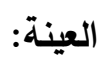

أختيرت جامعة الإسكندرية لإجراء هذه الدراسة على عينة صُدفية قوامها عـ1 ا من العاملين والعاملات بالجامعة. الحدود الزمنية للدراسة: استغرقت مدة العمل الميداني والدراسة التجريبية أربعة

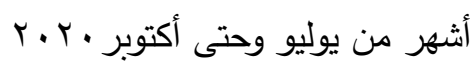


التجمعات، بحيث يطلب من المبحوث الاجابة عليها بنعم،

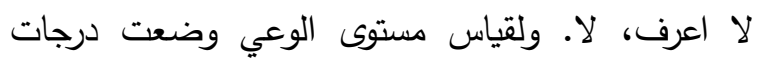

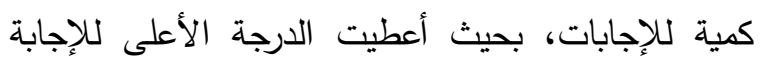

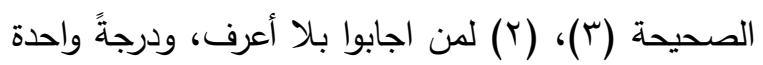
(1) (1) للإجابة الخاطئة.

البند الثالث: يتضمن (Y) (I) عبارة في الصورة المبدئية للاستبيان تعكس إجاباتها مستوى وعي عينة الدراسة بالتدابير الوقائية الواجب أخذها في الاعتبار أثناء تواجد

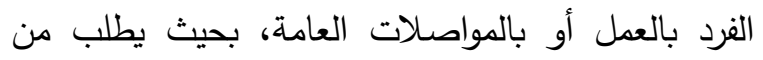

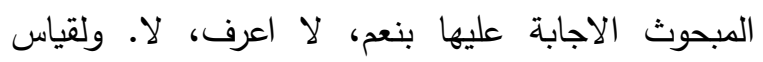

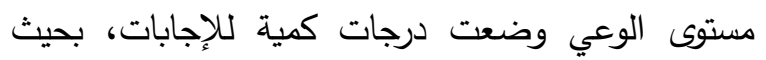

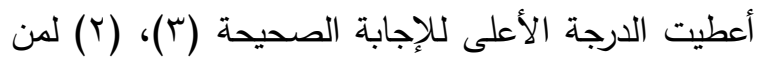
اجابوا بلا أعرف، ودرجةً واحدة ( ) للإجابة الخاطئة. المحور الخامس: يشتمل عل نفس البنود والعبارات في المحور الرابع، والتي تعكس اجاباتها مدى اتباع عينة الدراسة للتدابير الوقائية للوقاية من الاصابة بالفيروس، بحيث يطلب من المبحوث الاجابة عليها بدائما، احيانا، نادرا. ولقياس مدى اتباع عينة الدراسة للتدابير الوقائية وضعت درجات كمية للإجابات، بحيث اعطيت دائما (r)

$$
\text { واحيانا (r) ونادرا (1). }
$$

المحور السادس: تضمن أسئلة لتحديد أهم العوائق التي تواجه عينة الدراسة لاتباع التدابير الوقائية، بحيث يُطلب من المبحوث الاجابة عليها بنعم، لا. ولقياس شدة هذه

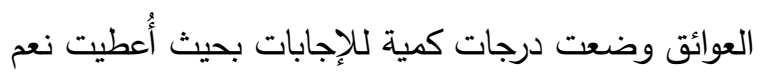

. (Y) (1)

المحور السابع: تضمن أسئلة للتعرف على الآثار النفسية والاجتماعية لعينة الدراسة والناتجة عن البقاء بالمنزل خلال فترة الحظر المنزلي، بحيث يُطلب من المبحوث الاجابة عليها بدرجة تأثر شديدة، درجة تأثر متوسطة،

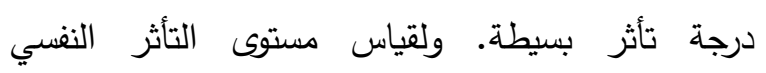
والاجتماعي لعينة الدراسة وُضعت درجات كمية
المحور الأول: اشتمل على بيانات عن الخصائص الاجتماعية - الاقتصادية لعينة الدراسة وهي الجنس العمر - المستوى التعليمي- منطقة السكن - الحالة الاجتماعية - نوع الوظيفة - عدد سنوات العمل - متوسط الاخل الشهري- وجود أبناء بالأسرة. المحور الثاني: تضمن أسئلة للتعرف على مصادر الحصول على معلومات عن فيروس كورونا المستجد. المحور الثالث: اشتمل هذا المحور على (اس) عبارة في الصورة المبدئية للاستبيان ،تعكس إجاباتها مستوى وعي عينة الدراسة حول أسباب انتشار وأعراض الإصابة بفيروس كورونا المستجد والفئات الأكثر عرضد للإصابة به، بحيث يختار المبحوث احد الاجابات نعم، لا اعرف، لا ل. ولقياس مستوى الوعي وضعت درجات كمية للإجابات

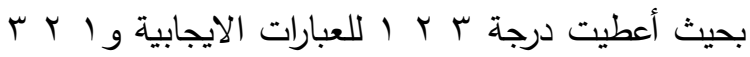

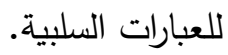
المحور الرابع: يتضمن دراسة وعي عينة الدراسة بالتدابير

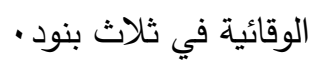
البند الاول: يقيس مستوى وعي عينة الدراسة بالتدابير الوقائية الخاصة بالنظافة الشخصية، واشتمل على (r ( ) عبارة في الصورة المبدئية للاستبيان تعكس اجاباتها مستوى الوعي بالتدابير الوقائية والمتعلقة بالنظافة

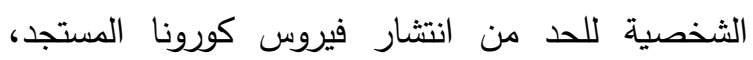
بحيث يطلب من المبحوث الاجابة عليها بنعم، لا اعرف، لا. ولقياس مستوى الوعي وضعت درجات كمية للإجابات، بحيث أعطيت الارجة الأعلى للإجابة الصحيحة (r)، (r) لمن اجابوا بلا أعرف، ودرجةً واحدة (1) ل لإججابة الخاطئة.

البند الثاني: يتضمن (IV) عبارة في الصورة المبدئية للاستبيان تعكس إجاباتها مستوى وعي عينة الدراسة بالتدابير الوقائية الخاصة بالتباعد الاجتماعي وكذلك ولكي التدابير الواجب أخذها في الاعتبار عند التسوق أو لواعيل 
محاور الاستبيان تم حذف بعض العبارات في بعض المحاور حتى تصل قيمة الفاكرونباخ اكثر من جان. ويوضح جدول(1) قيم معامل ألفاكرونباخ للاستبيان في صورته المبئية وفي صورته النهائية بعد حذف بعض

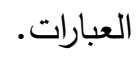

يلاحظ من جدول (1) أن قيم معامل ألفاكرونباخ لكل

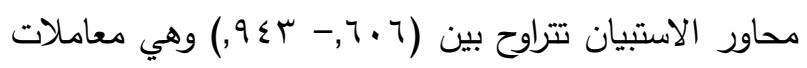
مرتفعة، وتجدر الإشارة إلى أن معامل ثبات ألفاكرونباخ تتراوح قيمته بين(صفر - 1) وكلما اقتربت قيمته من الواحد الصحيح دل ذلك على وجود ثبات عالي، وكلما اقتربت قيمته من الصفر دل ذلك على انخفاض ثبات الاستبيان، وأن الحد وجدي

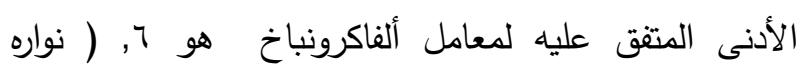
المحارب, r ب • وهذا يدل على أن أداة الدراسة (الاستبيان) على درجة عالية من الثبات وهذا يؤكد على صحة الاستبيان

$$
\text { وصلاحيته للاستخدام في الدراسة. }
$$

للإجابات، بحيث أعطيت درجة التأثر الثديدة (1)، درجة

التأثر المتوسطة (r)، درجة التأثر البسيطة (r). r - اختبار صدق وثبات الاستبيان: لاختبار صدق وثبات الاستبيان تم تطبيق الاستبيان في الصورة الأولية على عينة من العاملين بجامعة الإسكندرية بلغ عددهم (·r)، ثم تم تفريخ البيانات باستخدام برنامج الحزمة الاحصائية للعلوم الاجتماعية (SPS V 23)، ثم تم اجراء المعاملات الاحصائية لاختبار صدق وثبات الاستبيان الذي تم اعداده في الصورة المبدئية. - - - اختبار ثبات الاستبيان: يقصد بثبات أداة الدراسة أن يعطي الاستبيان نفس النتيجة عند تطبيقه مرة أخرى في نفس الظروف على عينة مشابهة. وقد تم التحقق من ثبات استبيان الدراسة بحساب معامل ألفاكرونباخ Alpha cronbach,s للاستبيان في الصورة المبئية، وبناء على نتائج معامل الفاكرونباخ لكل محور من

جدول ا ـ قيم معامل ألفاكرونباخ وعدد العبارات لكل محور من محاور الاستبيان قبل وبعد حذف عدد من العبارات

\begin{tabular}{|c|c|c|c|c|c|c|}
\hline \multirow{2}{*}{ ع المحذوفة إل } & \multicolumn{2}{|c|}{ بعد الحذف } & \multicolumn{2}{|c|}{ قبل الحذف } & \multirow{2}{*}{\multicolumn{2}{|c|}{ محاور الاستبيان }} \\
\hline & 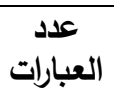 & معامل & 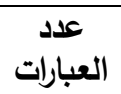 & معامل & & \\
\hline r & rq &, $7 \cdot 7$ & 蒋 & , or 1 & بفيروس كورونا المستجد وأعراض والفئات الأكثر عرضـة للإصـابة & الثالثور \\
\hline- & IT &, 71 & IT & , 1 . & الوعي بالتدابير الوقائية الخاصة بالنظافة الثخصية & \\
\hline- & iv &, 110 & iv &,$\wedge 10$ & التسوقي والتـدابير الوقائية الخاصـة بالتباعد الاجتماعي وعند & اللإحور \\
\hline- & ir &, $\mathrm{V} \wedge \mathrm{A}$ & ir &,$\vee r \wedge$ & العامةٍ بالتدابير الوقائية الخاصـة بيئية العمل والمواصـلات & الرابح \\
\hline- & Ir & , АTr & ir & , А־ & اتباع التدابير الوقائية الخاصة بالنظافة الشخصية & \\
\hline- & IV & , qTV & IV & $9 r v$ & التبوق والتجمعات التوقائيـة الخاصـة بالتباعد الاجتمـاعي وعند & الخامور \\
\hline- & Ir &, $9 \leqslant r$ & ir &,$q \leqslant r$ & 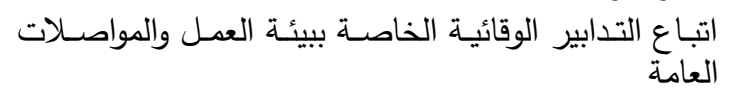 & \\
\hline
\end{tabular}


معنوية ا •.,. ومنه يتحقق صدق الاستبيان والاتساق الداخلي - اختبار صدق الاستبيان: -

للأداة لمعظم محاور الاستبيان. r- تحليل البيانات احصائيا:

يقصد بصدق أداة الدراسة أن تقيس عبارات الاستبيان ما

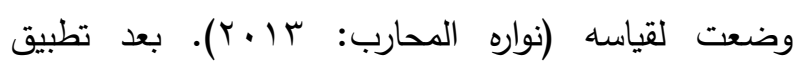
- تحويل البيانات الوصفية الى كمية:

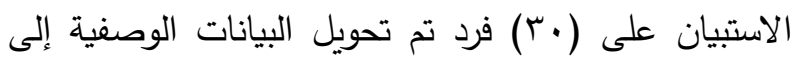
كمية في كل محور استعداداً لحساب معامل ارتباط "بيرسون" تم تحويل البيانات الوصفية الى كمية لكل محور من بين درجة كل بند من بنود المحور مع الدرجة الكلية لنفس محور ، كما تم حساب الفئات كما يلي: المحور، وانطبق هذا على محاور الوعي والممارسات ببنودهما، ويوضتح جدول(Y) قيم معامل ارتباط "بيرسون" لكل الدرجة الصغرى لكل من الوعي واتباع التدابير الوقائية =

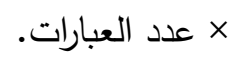
محور من محاور الاستبيان قبل وبعد حذف بعض العبارات.

الارجة العظمى لكل من الوعي واتباع التدابير الوقائية = ب ل من جدول (Y) يلاحظ قيم معامل ارتباط "بيرسون" بين كل محور من محاور الوعي واتباع التدابير الوقائية للحد من ويشير جدول(r) الى الدرجة الصغرى والعظمى والفئات بكل محور من محاور الاستبيان. الاصابة بفيروس كورونا المستجد والدرجة الكلية للوعي ولي

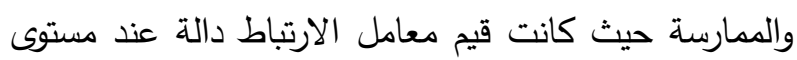
جدول r . قيم معامل ارتباط "بيرسون" لمحاور الاستبيان قبل وبعد حذف بعض العبارات

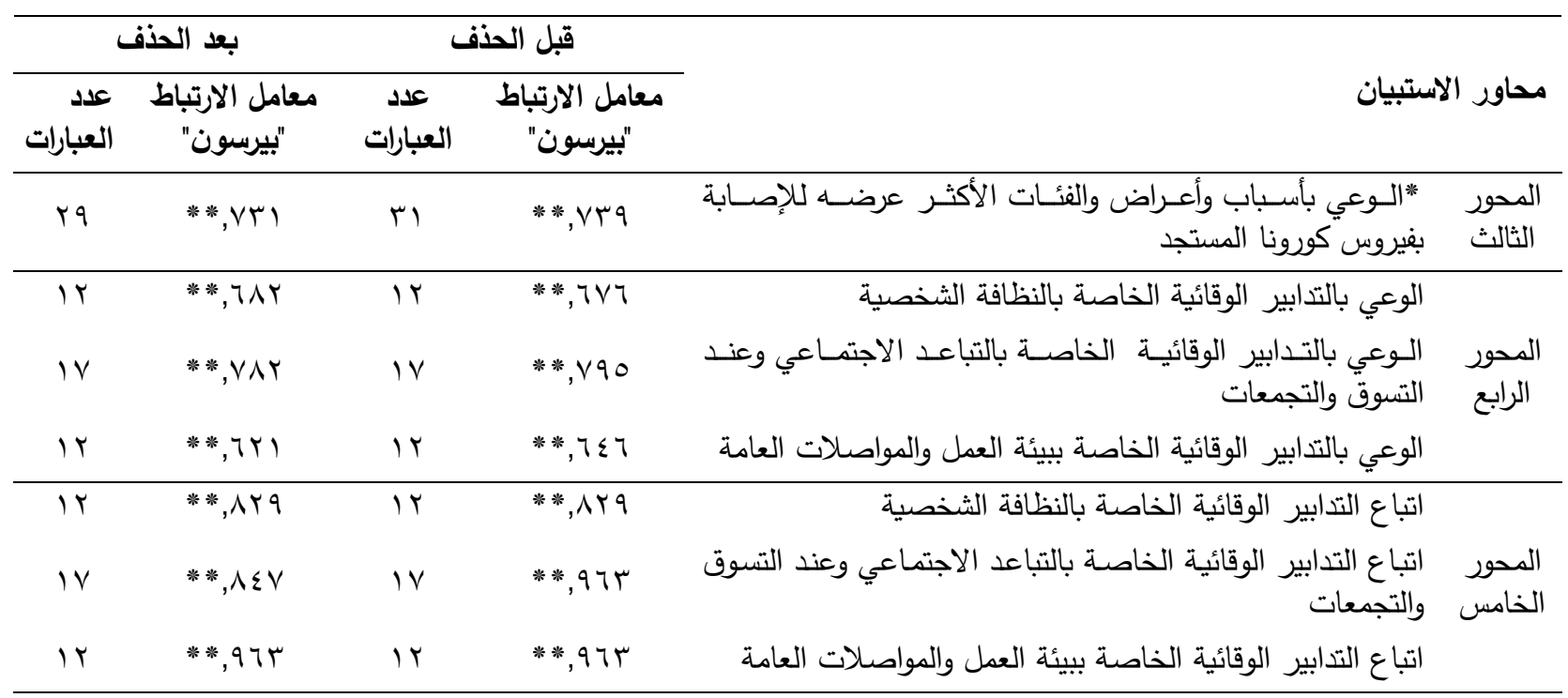


مستوبات الوعي

جدول r. درجات ومستويات الوعي بأسباب وأعراض مرض فيروس كورونا والتدابير الوقائية الواجب اتباعها

\begin{tabular}{|c|c|c|c|c|c|c|}
\hline اجمالي الوعي & الوائتابيّير كلي & البيئة العملاتيل & والتبدوبيز & الثخابيزي & وأعراضٍ الإصنابة بأبير & G \\
\hline r.. & ITr & דיז & 01 & T & NV & الدرجة العظمى \\
\hline v. & § & ir & iv & ir & rq & الدرجة الصغرى \\
\hline r. & Tr & צי & 01 & די & AV & أكبر درجة مشاهدة \\
\hline Kr & 01 & $1 \varepsilon$ & ro & ir & $0 \leqslant$ & أصغر درجة مشاهدة \\
\hline 14 & Vr & r & ד r & $r \varepsilon$ & זr & 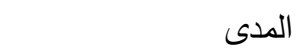 \\
\hline rq & $r \varepsilon$ & V & 9 & ᄉ & 11 & طول الفئة \\
\hline $10 r>-1 T \varepsilon$ & $V 0>-01$ & $|r|>-1 \varepsilon$ & $r \varepsilon>-r_{0}$ & $r \cdot>-1 Y$ & $10>-0 \leqslant$ & فئة الوعي الضعيف \\
\hline $\begin{array}{c}1 \Lambda r>-10 r \\
\text { فأكثر } 10 r\end{array}$ & 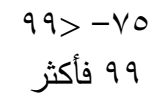 & 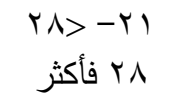 & 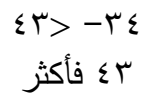 & 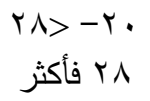 & 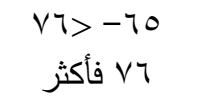 & فئة الوعي الوعي" المتوسط \\
\hline
\end{tabular}

جدول ء. درجات ومستويات ممارسات أفراد العينة لاتباع التدابير الوقائية للوقاية من الإصابة بالفيروس

\begin{tabular}{|c|c|c|c|c|}
\hline التباع التابير & اتباع تدابير بيئة العمل & والتسبوق والتجمعات التباعد & اتباع تدابير النظافة & الممارسة \\
\hline TKr & די & 01 & ד & الدرجة العظمى \\
\hline « & ir & iv & ir & الدرجة الصغرى \\
\hline rr & דיץ & 01 & 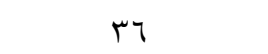 & أكبر درجة مشاهدة \\
\hline 纟o & ir & iv & ir & أصغر درجة مشاهدة \\
\hline VA & $r \varepsilon$ & $r \varepsilon$ & $r \varepsilon$ & 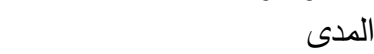 \\
\hline ry & $\wedge$ & 11 & $\wedge$ & طول الفئة \\
\hline$v_{1}>-\varepsilon 0$ & $r \cdot>-1 r$ & $r \wedge>-1 V$ & $r \cdot>-1 r$ & فئة الممارسات الضعيفة \\
\hline $\begin{array}{l}q V>-V 1 \\
\text { فأكثر qv }\end{array}$ & 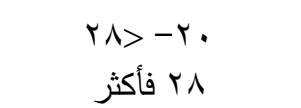 & 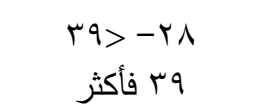 & 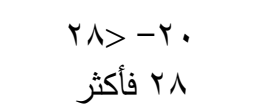 & فئئة الممارسات الجيدة المتوسطة \\
\hline
\end{tabular}

جدول ه. مستويات الآثار النفسية والاجتماعية الناتجة عن الحظر المنزلي وعوائق اتباع التدابير الوقائية

\begin{tabular}{|c|c|c|c|}
\hline عوائق اتباع التدابير الوقائية & الارجات والمستويات & الآثار النفسية والاجتماعية & الارجات والمستويات \\
\hline $1 \leq$ & الدرجة العظمى & $r q$ & الدرجة العظمى \\
\hline$v$ & الدرجة الصغرى & r & الدرجة الصغرى \\
\hline $1 \leq$ & أكبر درجة مشاهدة & ץ & أكبر درجة مشاهدة \\
\hline$\checkmark$ & أصغر درجة مشاهدة & r & أصغر درجة مشاهدة \\
\hline$v$ & 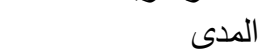 & ro & 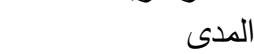 \\
\hline r & طول الفئة & 11 & طول الفئة \\
\hline $1 \cdot>-V$ & فئة العوائق الثديدة & $r \mid>-1 r$ & فئة التأثر الشديد \\
\hline • أ أكثر & فئة العوائق البسيطة & 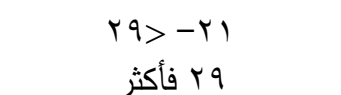 & فئئة التأثر المتوسط السيط \\
\hline
\end{tabular}


العينة عن نوع الوظيفة وجد أن ع.بـ ٪ يشغلوا وظائف ادارية

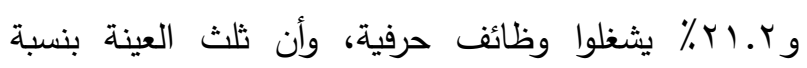

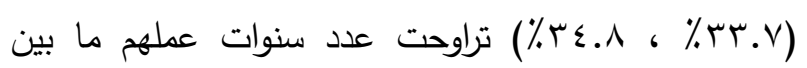

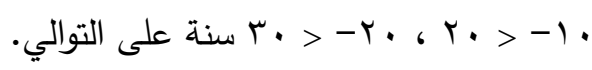
وبسؤال افراد العينة عن مصادر حصولهم على معلومات

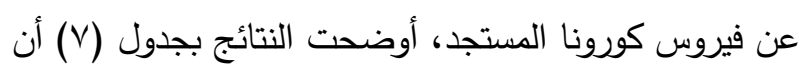

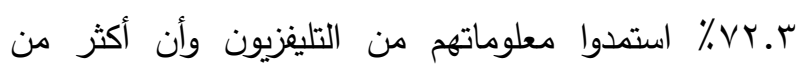

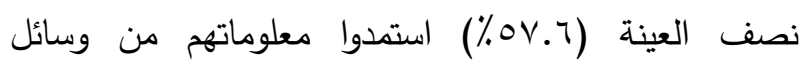
التواصل الاجتماعي يليها الأقارب والأصدقاء حيث بلغت

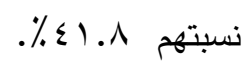

\section{النتائج والمناقشة}

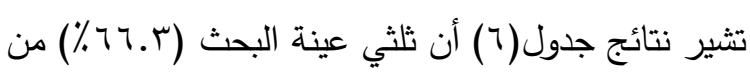

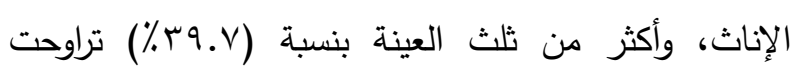

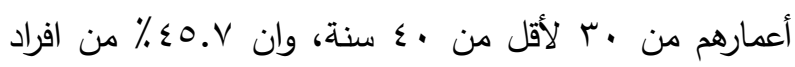

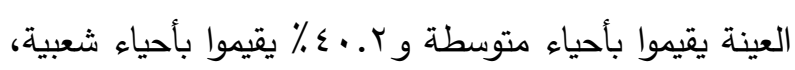

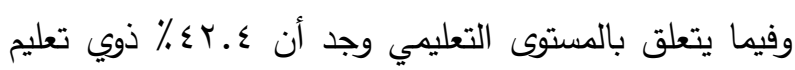

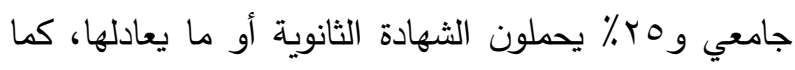

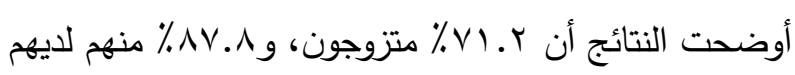
أبناء، وبسؤال افراد

\begin{tabular}{|c|c|c|c|c|c|}
\hline$\%$ & عدد & الخصائص & $\%$ & عدد & الخصائص \\
\hline & & نوع الوظيفة & & & الجنس \\
\hline r. & TV & مهني & Tr.V & Tr & ذكور \\
\hline$\varepsilon Y . \varepsilon$ & $\vee \wedge$ & إداري" & T. & Irr & إناث \\
\hline YI. & rq & حرفي & $1 \ldots$ & $1 \wedge \varepsilon$ & المجموع \\
\hline \multirow[t]{2}{*}{$1 \ldots$} & $1 \wedge \varepsilon$ & المجموع & & & \\
\hline & & عدد سنوات العمل & & & العمر بالسنوات \\
\hline 17,1 & r & $1 \cdot>$ & $10 . r$ & rA & $r \cdot>$ \\
\hline 每,V & Tr & $r \cdot>-1$. & ५৭.v & $v r$ & $\varepsilon \cdot>-\mu$. \\
\hline$r \varepsilon, \Lambda$ & $7 \varepsilon$ & $r \cdot>-r \cdot$ & Tr.s & $\varepsilon r$ & $0 .>-\varepsilon$. \\
\hline $1 \leq, V$ & rV & • ا ب فأكثر & YI,V & $\varepsilon$. & $7 \cdot>-0$. \\
\hline \multirow[t]{2}{*}{$1 \cdots$} & $1 \wedge \varepsilon$ & المجموع & $1 \ldots$ & $11 \varepsilon$ & المجموع \\
\hline & & متوسط الدخل الشهري & & & منطقة السكن \\
\hline r,. & ov & $r \ldots>$ & $\varepsilon \cdot, r$ & $V \varepsilon$ & شعبي \\
\hline$\varepsilon 1, \wedge$ & $V V$ & $r \ldots>-r_{\ldots} .$. & $\varepsilon 0, V$ & $\Lambda \varepsilon$ & متوسط" \\
\hline$r V, r$ & 0 & أ. . . . فأكثر & $1 \leqslant, 1$ & $r y$ & راقي \\
\hline \multirow[t]{2}{*}{$1 \ldots$} & $11 \varepsilon$ & المجموع & $1 \cdots$ & $11 \varepsilon$ & المجموع \\
\hline & & الحالة الاجتماعية & & & المستوى التعليمي \\
\hline$r \wedge, \Lambda$ & or & غير متزوج & $\varepsilon, r$ & $\wedge$ & \\
\hline$V, Y$ & וr & متزوج & 1,9 & 9 & يقراً ويكتب \\
\hline \multirow[t]{3}{*}{$1 \cdots$} & $1 \wedge \varepsilon$ & المجموع & $\varepsilon, 9$ & 9 & ابتدائية \\
\hline & & & $0, \Sigma$ & 1. & اعدادية \\
\hline & & وجود أبناء بالأسرة (ن=I III) & ro,. & $\leq 7$ & ثانوية أو ما يعادلها \\
\hline$\wedge \mathrm{V}, \wedge$ & 110 & يوجد & $\varepsilon r, \varepsilon$ & $\vee \wedge$ & شهادة جامعية \\
\hline$M, Y$ & 17 & ل لا يوجد & IT, & $r \varepsilon$ & دراسات عليا \\
\hline $1 \cdots$ & 141 & المجموع & $1 \cdots$ & $11 \varepsilon$ & المجموع \\
\hline
\end{tabular}


جدول V. توزيع افراد العينة وفقاً لمصادر حصولهم على معلومات عن فيروس كورونا المستجد ن=ع 1 1

\begin{tabular}{|c|c|c|c|c|c|c|c|c|}
\hline \multirow{2}{*}{\multicolumn{2}{|c|}{ المجموع }} & \multicolumn{6}{|c|}{ الحصول على المعلومات } & \multirow{3}{*}{ مصادر المعلومات } \\
\hline & & \multicolumn{2}{|c|}{ بلدرجة قليلة } & \multicolumn{2}{|c|}{ أحياناً: } & \multicolumn{2}{|c|}{ بدرجة كبيرة } & \\
\hline$\%$ & عدد & $\%$ & عدد & $\%$ & عدد & $\%$ & عدد & \\
\hline $1 \ldots$ & $1 \wedge \varepsilon$ & $\Lambda, \vee$ & 17 & 19, & ro & $V Y, r$ & (Tr & التليفزيون \\
\hline $1 \ldots$ & $1 \wedge \varepsilon$ & 07, & $1 \cdot r$ & $r \leq, r$ & מז & $9, \wedge$ & 11 & 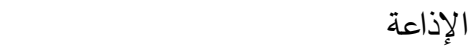 \\
\hline $1 \ldots$ & $1 \wedge \varepsilon$ & $1 \leqslant, V$ & rV & $r V, V$ & 01 & $\Delta V, 7$ & 1.7 & وسائل التواصل الاجتماعي \\
\hline $1 \ldots$ & $1 \wedge \varepsilon$ & ro,. & $\varepsilon 7$ & r, & I & $\varepsilon, \wedge$ & $V V$ & الأقارب والأصدقاء \\
\hline $1 \ldots$ & $1 \wedge \varepsilon$ & $\varepsilon \Lambda, \varepsilon$ & 19 & YI,Y & rq & $r \cdot, \varepsilon$ & 07 & موقع منظمة الصحة العالمية بمصر \\
\hline $1 \ldots$ & $1 \wedge \varepsilon$ & $\leqslant 9,0$ & 91 & $r q, r$ & $0 \leqslant$ & YI, & rq & المواقع الحكومية بالشبكات الاجتماعية \\
\hline $1 \ldots$ & $1 \wedge \varepsilon$ & OY,Y & 97 & $r, \Lambda$ & $\varepsilon r$ & ro,. & $\varepsilon 7$ & وزارة الصحة والسكان المصرية \\
\hline
\end{tabular}

يتضح من جدول (^) أن الغالبية العظمى من افراد العينة

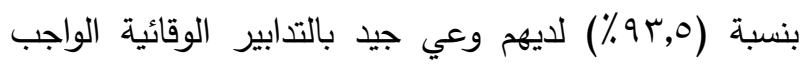
إتباعها للحد من انتثار الفيروس، وتتقق هذه النتيجة مع دئ دراسة Abdelhafiz, et al(2020 والتي أجريت بهدف تقييم معارف واتجاهات الثعب المصري تجاه مرض كوفيد-9 (أه حيث وُجد أن أفراد العينة لديهم وعي جيد حول الفيروس واتجاهات ايجابية نحو تدابير الحماية، وأن هذا الوعي تم

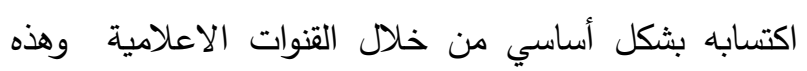
النتيجة تلقي الضوء على ما قامت به وسائل الإعلام المرئية والمسموعة والالكترونية من دور هام في توعية الأفراد بأهمية الإجراءات التي يجب على المواطن اتخاذها والالتزام بها كي يحمي نفسه وعائلته من الإصابة بالفيروس باعتبار أن وعي

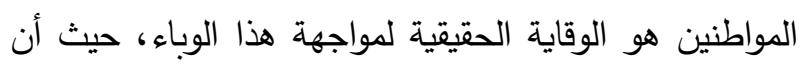
برامج التوعية التي اتبعتها الدول والمنظمات العالمية ومنظمات المجتمع للوقاية من الفيروس كانت أهم سلاح في مواجهته والحد من انتشاره، كما اوضحت النتائج البحثية

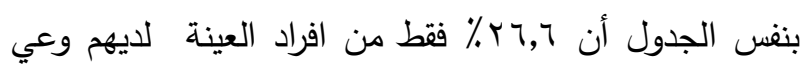
جيد بأسباب انتشار وأعراض الإصابة بفيروس كورونا

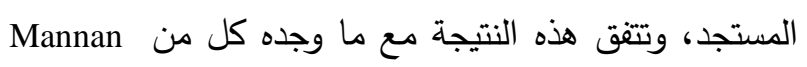

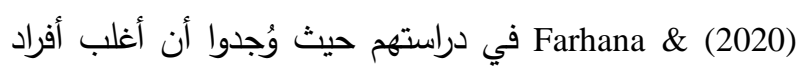
العينة كان وعيهم ضعيف فيما يتعلق بأعراض الفيروس

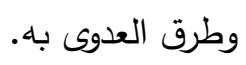

مما سبق يتضح أن أغلب افراد العينة اتجهوا لمتابعة أزمة كورونا من خلال القنوات الفضائية الاخبارية بشكل كبير ، ولعل ذلك يعود إلى أن هذه القنوات تمكنت من مواكبة الحدث لحظة بلحظة، وتخصيص مساحات من البث لهذه

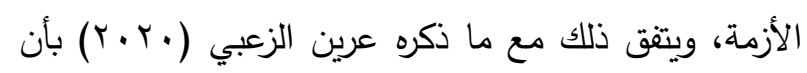
القنوات الفضائية بذلت قصارى جهدها بتغطيتها الإعلامية حول أزمة كورونا، ومتابعة الأزمة بكافة مراحلها، وإمداد

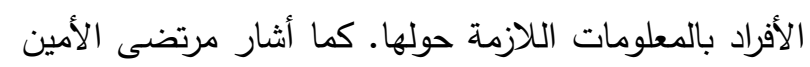

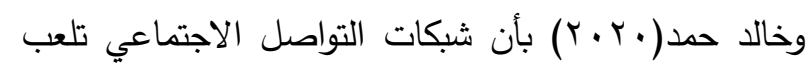
دوراً هاماً ومركزياً في نشر المعلومات هيث تُكن بـن المستخدمين بإمكانيات هائلة في التواصل أفراداً وجماعات، مما يعني الحصول على درجة عالية من التأثير إذا ما تم توظيفها بطريقة صحيحة ومدروسة خاصة عند الأزمات لأنها تتيح فرصة التفاعل مع المجتمع محل الأزمة ووضعه في الصورة وهذا ما يزيد من أهميتها لمقابلة جائحة كورونا المستجد وفي دراسة أجراها Mannan(2020) Farhana

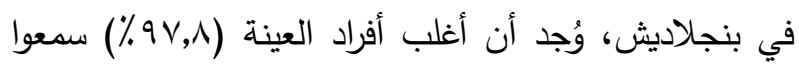
عن فيروس كورونا المستجد من خلال وسائل التواصل الاجتماعي. 


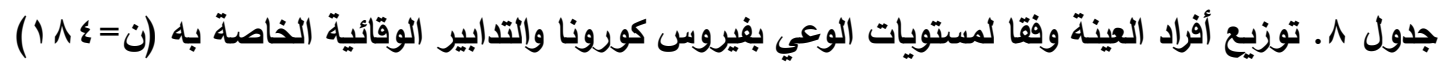

\begin{tabular}{|c|c|c|c|c|c|c|c|c|c|}
\hline \multirow{2}{*}{\multicolumn{2}{|c|}{ المجموع }} & \multicolumn{6}{|c|}{ مستوى الوعي } & & \multirow{3}{*}{ الوعي } \\
\hline & & \multicolumn{2}{|c|}{ ضعيف } & \multicolumn{2}{|c|}{ متوسط } & \multicolumn{2}{|c|}{ جيا } & & \\
\hline$\%$ & عدد & $\%$ & عدد & $\%$ & عدد & $\%$ & عدد & & \\
\hline $1 \cdots$ & $1 \wedge \varepsilon$ & $1 \varepsilon, r$ & ry & $09, Y$ & 1.9 & $Y \uparrow, \uparrow$ & $\sum 9$ & 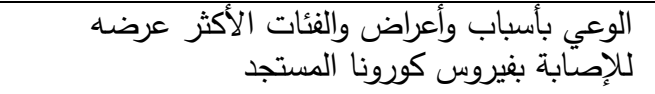 & \\
\hline $1 \cdots$ & $1 \wedge \varepsilon$ & $\cdot, 0$ & 1 & $\cdot, 0$ & 1 & $99, \cdot$ & INr & الوعي بالتدابير الوقائية الخاصة بالنظافة الثخصية & 3 \\
\hline $1 \cdots$ & $1 \wedge \varepsilon$ & $r, r$ & $\varepsilon$ & 7,0 & ir & $91, r$ & 171 & وعند التسوق بالتدابير الوقائية الخاصة بالتباعد الاجتماعي & 司 \\
\hline $1 \cdots$ & $1 \wedge \varepsilon$ & r,, $\mathrm{r}$ & 0 & r,^ & V & 94,0 & IVT & والموأصي بالتدابير العامة الوقية الخاصة ببيئة العمل & 尔 \\
\hline $1 \cdots$ & $1 \wedge \leq$ & 1,1 & r & $0, \varepsilon$ & 1. & $9 r, 0$ & IVT & الوعي بالتدابير الوقائية ككل & 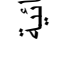 \\
\hline $1 \ldots$ & $1 \wedge \varepsilon$ & $r, r$ & $\varepsilon$ & IV, $\Sigma$ & r & $\Lambda \cdot, \varepsilon$ & $1 \leq 1$ & الوعي & إجمالي \\
\hline
\end{tabular}

يتضح أن جهود التوعية بفيروس كورونا كانت الأعلى في التئي

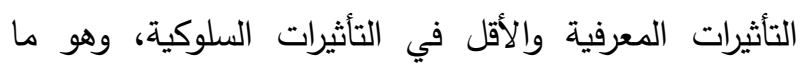

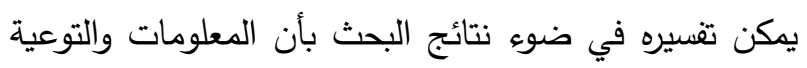

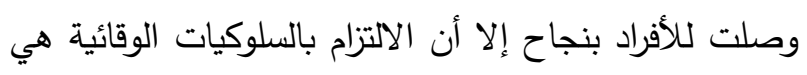

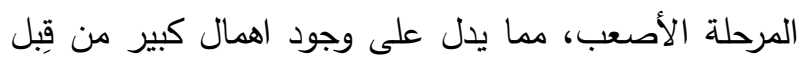

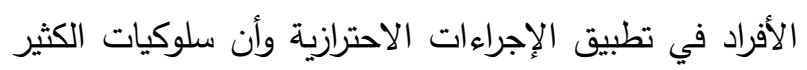
من الأفراد تحتاج إلى تغيير سريع لأن الفرد عليه مسئولية الأني

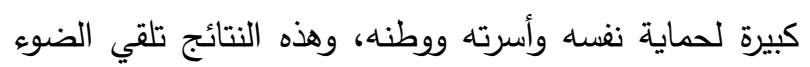
على أهمية إعداد برامج ارشادية لتعديل سلوكيات الأفراد باعتبارها طوق النجاة الحقيقي للوقاية من الاصنابة بالفيروس.
يعرف الوعي الصحي بأنه إلمام المواطنين بالمعلومات

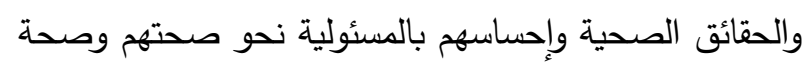
غيرهم، فالوعي الصحي ممارسة تتم عن قصد نتيجة الفِهم والاقتناع، ويعني أن تتحول الممارسات الصحية إلى عادات

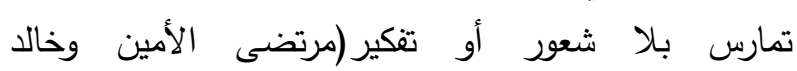

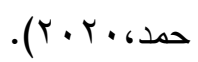
تبين من النتائج البحثية بجدول (9) أن ^,بr\% من افراد

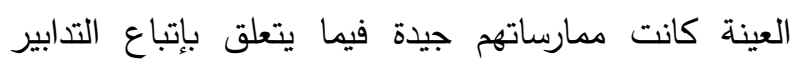

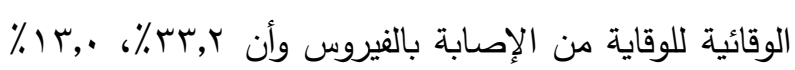

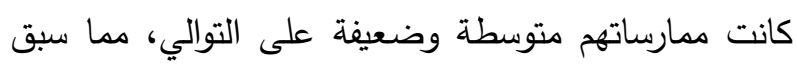

جدول 9.

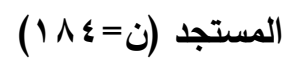

\begin{tabular}{|c|c|c|c|c|c|c|c|c|}
\hline \multirow{2}{*}{\multicolumn{2}{|c|}{ المجموع }} & \multicolumn{6}{|c|}{ مستوى الممارسة } & \multirow{3}{*}{ اتباع التدابير الوقائية } \\
\hline & & \multicolumn{2}{|c|}{ ضعيفة } & \multicolumn{2}{|c|}{ متوسطة } & \multicolumn{2}{|c|}{ جيدة - } & \\
\hline$\%$ & عدد & $\%$ & عدد & $\%$ & عدد & $\%$ & عدد & \\
\hline $1 \cdots$ & $1 \wedge \varepsilon$ & $r, \wedge$ & V & $r \cdot, l$ & re & $v 4,1$ & $1 \leq$. & اتباع التدابير الوقائية بالنظافة الثخصية \\
\hline $1 \cdots$ & $1 \wedge \varepsilon$ & $10, r$ & rA & ए,. & ov & or, , & 99 & 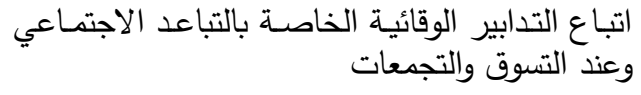 \\
\hline $1 \cdots$ & $1 \wedge \varepsilon$ & $r, r$ & $\varepsilon 1$ & $r \wedge, r$ & or & $\varepsilon 9, \varepsilon$ & 91 & 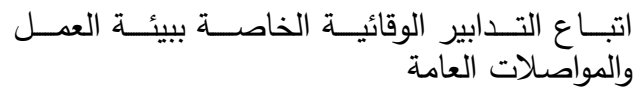 \\
\hline $1 \cdots$ & $1 \wedge \varepsilon$ & 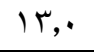 & $r \varepsilon$ & ru, & 71 & or, , & 99 & اتباع التدابير الوقائية ككل \\
\hline
\end{tabular}


واجهتهم، وقد يرجع ذلك إلى زيادة الطلب على الكمامات والمطهرات بعد أزمة تفثي الفيروس مما أدى لوجود نقص بلصاء فيها وارتفاع أسعارها.

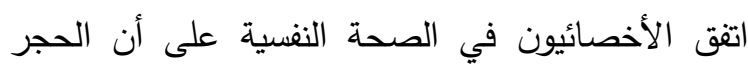
المنزلي المفروض على أكثر من مليار شخص حول العالم بسبب جائحة فيروس كورونا ليس أمراً سهلاً، إذ أنه إجراء

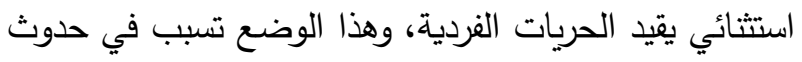
مشكلات نفسية للعديد من الأشخاص (مسعودة فلوس الترات

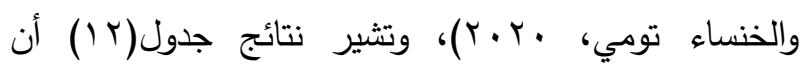

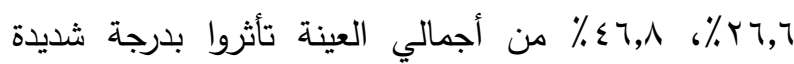

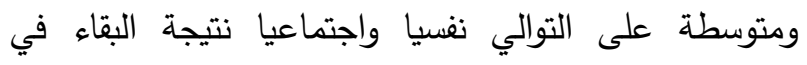
المنزل خلال فترة الحظر وقد يرجع ذلك نتيجة الخوف والقلق المستمر حول مستقبلهم وحول ما الذي سيؤولون اليه بعد هذا

$$
\text { الوضع الصحي الخطير - مان. }
$$

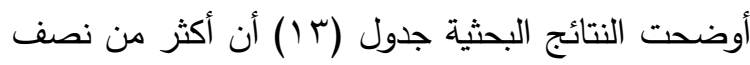

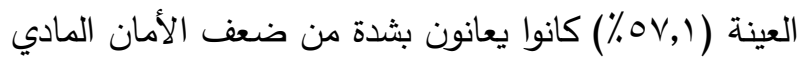

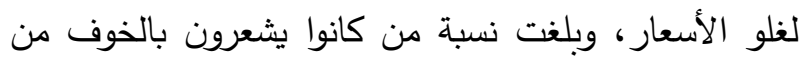

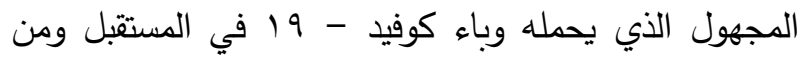
شعروا بالملل نتيجة الحظر المنزلي والخوف من الموت من

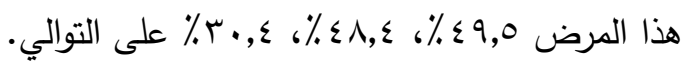

أوضحت النتائج البحثية بجدول(·() أن أكثر من نصف

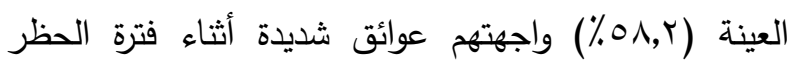
المنزلي وعند اتباع التدابير الوقائية، في حين بلغت نسبة من واجهتهم عوائق بسيطة (^,1؟\%). وقد افادت نهلة علي

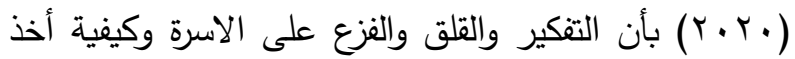
الاجراءات الوقائية للمحافظة عليها من انتثار المرض، وفي التي نفس الوقت التنكير في العمل وكيفية انجازه في ظل الظروف

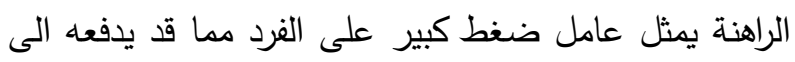
الاصابة بالأمراض النفسجمية والتي ترجع الى العوامل النفسية والانفعالية في الاساس. جدول · ـ ا ـ توزيـع أفراد العينـة وفقـاً لثـدة العوائق التـي واجهته أثناء الحظر المنزلي وغند اتباع التدابير الوقائية

$(1 \wedge \varepsilon=\dot{0})$

\begin{tabular}{|c|c|c|}
\hline$\%$ & عدد & العوائق \\
\hline $0 \Lambda, Y$ & $1 . V$ & عوائق شديدة \\
\hline$\varepsilon 1, \wedge$ & VV & عوائق بسيطة \\
\hline $1 \ldots$ & $1 \Lambda \varepsilon$ & المجموع \\
\hline
\end{tabular}

بسؤال افراد العينة عن العوائق التي واجهتهم أثناء الحظر المنزلي وعند إتباع التدابير الوقائية أثناء جائحة

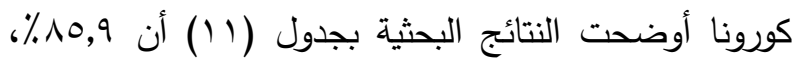

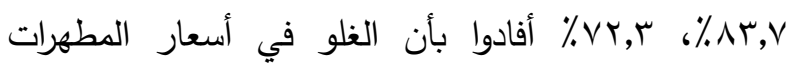

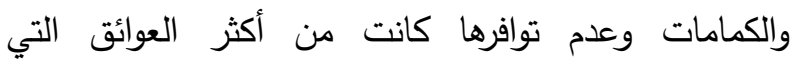

جدول 11. توزيع افراد العينة وفقاً للعوائق التي واجهتهم أثناء الحظر المنزلي وعند اتباع التدابير الوقائية (ن=ء1 1)

\begin{tabular}{|c|c|c|c|c|c|c|}
\hline \multicolumn{2}{|c|}{ المجموع } & \multicolumn{2}{|c|}{ لا } & \multicolumn{2}{|c|}{ نعم } & \multirow[b]{2}{*}{ العوائق } \\
\hline$\%$ & عدد & $\%$ & عدد & $\%$ & عدد & \\
\hline $1 \ldots$ & $1 \wedge \varepsilon$ & AY,T & $10 \mathrm{r}$ & $i v, \varepsilon$ & re & الخوف من الدخول في أجازه غير مدفوعة الأجر خلال الحظر \\
\hline $1 \ldots$ & $1 \Lambda \varepsilon$ & Ar, & 101 & $1 v, q$ & r & الخوف من تقليص سآعات العمل وتأثر الراتب \\
\hline $1 \ldots$ & $1 \wedge \varepsilon$ & $17, r$ & r. & $\Delta r, \mathrm{v}$ & $10 \leqslant$ & الغلو في أسعار الكمامات \\
\hline $1 \ldots$ & $1 \wedge \varepsilon$ & $1 \leqslant, 1$ & ז & 10,9 & 101 & الغلو في أسعار المطهرات \\
\hline $1 \ldots$ & $1 \wedge \varepsilon$ & $r V, \gamma$ & 01 & VY, r & Tra & عدم توافَّر الكمامات \\
\hline $1 \ldots$ & $1 \Lambda \varepsilon$ & r & 71 & $74, \Lambda$ & Tr & عدم توافر التفازات الطبية (الجوانتى) \\
\hline $1 \ldots$ & $1 \Lambda \varepsilon$ & r, & 09 & $T V, q$ & iro & عدم توافر الكحول \\
\hline
\end{tabular}


هذا الفرض تم إجراء اختبار"ت"، اشارت النتائج البحثية بجدول (ع ا) وجود فروق معنوية بين متوسط درجات الذكور والإناث في الوعي بأسباب وأعراض مرض كورونا المستجد وكذلك الوعي الكلي لصالح الإناث حيث بلغت قيمة "ت" -

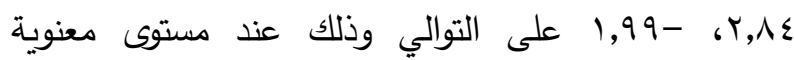
ا.,.•، 0 .,.•على التوالي، كما وُجدت فروق معنوية بين متوسط درجات الوعي الكلي لدى افراد العينة غير المتزوجين والمتزوجين لصالح المتزوجين، حيث بلغت قيمة "ت" -

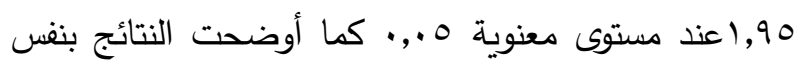

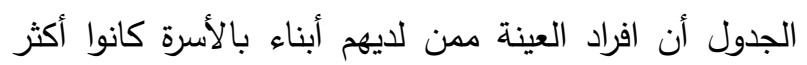

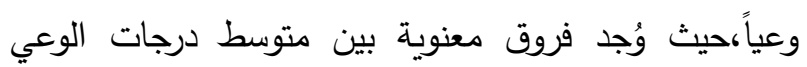
بالتدابير الوقائية ككل والوعي الكلي لدى افراد العينة ممن

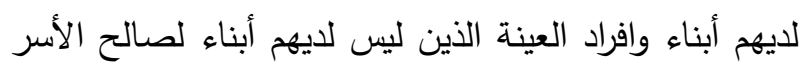

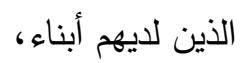

جدول r ا ـ توزيـع أفراد العينـة وفقـاً لارجـة التأثر النفسي

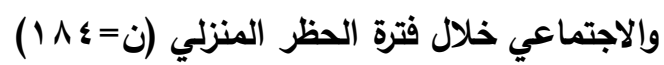

\begin{tabular}{|c|c|c|}
\hline$\%$ & عدد & درجة التأثر \\
\hline$r \uparrow, 7$ & $\leqslant 9$ & تأثر شديد \\
\hline$\leq 7, \wedge$ & $\wedge 7$ & تأثر متوسط \\
\hline ז & $\leqslant 9$ & تأثر ضعيف \\
\hline $1 \ldots$ & $1 \wedge \varepsilon$ & المجموع \\
\hline
\end{tabular}

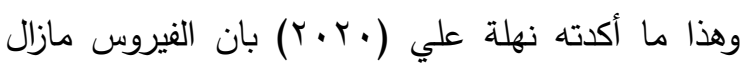
يواصل تفشيه بوتيرة متسارعة في مختلف أنحاء العالم، الامر الذي ساهم بشكل كبير في مضاعفة الضغوط النفسية على بلى جميع فئات المجتمع.

\section{نتائج الفروض البحثية}

الفرض الأول: ينص هذا الفرض على أنه "لا يوجد فروق معنوية بين نوع الجنس والحالة الاجتماعية ووجود أبناء، وكل لهل من الوعي بأسباب وأعراض مرض فيروس كورونا المستجد والوعي بالتدابير الوقائية الواجب اتباعها". ولاختبار صحة صورئ

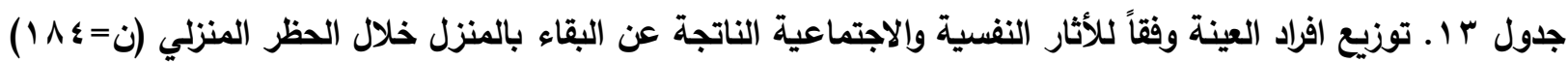

\begin{tabular}{|c|c|c|c|c|c|c|c|c|}
\hline \multirow{2}{*}{\multicolumn{2}{|c|}{ 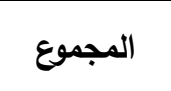 }} & \multicolumn{6}{|c|}{ درجة التأثر } & \multirow{3}{*}{ لأثار النفسية والاجتماعية } \\
\hline & & \multicolumn{2}{|c|}{ ضعيفة } & \multicolumn{2}{|c|}{ متوسطة } & \multicolumn{2}{|c|}{ شديلة } & \\
\hline$\%$ & عدد & $\%$ & عدد & $\%$ & عدد & $\%$ & عدد & \\
\hline $1 \cdots$ & $1 \wedge \varepsilon$ & rᄉ, & $\checkmark \cdot$ & $r \leqslant, r$ & $4 \pi$ & $r V, V$ & 01 & التوتر في العلاقات الأسرية نتيجة الجلوس بالمنزل \\
\hline $1 \cdots$ & $1 \wedge \varepsilon$ & $r \leqslant, r$ & ז4 & $r r, q$ & $\varepsilon \varepsilon$ & $\varepsilon, \wedge$ & $\checkmark V$ & تعطيل التروتين اليومي للحياة يصيب الفرد بالتوتر والعصبية. \\
\hline $1 \cdots$ & $1 \wedge \varepsilon$ & $r r, q$ & $\leqslant \varepsilon$ & $r V, V$ & 01 & $\varepsilon \wedge, \varepsilon$ & $\wedge 9$ & التواجد بالمنزل يؤدي للشعور بالملل. \\
\hline $1 \cdots$ & $1 \wedge \varepsilon$ & $r, \Lambda$ & $\varepsilon r$ & $\varepsilon 1, r$ & $\sqrt{ } 7$ & ro,9 & 77 & عدم المقدرة على أداء المجاملات في الحزن والفرح. \\
\hline $1 \ldots$ & $1 \wedge \varepsilon$ & 17,1 & r & rч, & $\varepsilon \wedge$ & $o \vee, 1$ & 1.0 & ضعف الأمان المادي لغلو الاسعار. \\
\hline $1 \ldots$ & $1 \wedge \varepsilon$ & $\varepsilon r, 0$ & $\wedge$. & 19, & ro & $r v, 0$ & 79 & الخوف من العدوى والمرض. \\
\hline $1 \cdots$ & $1 \wedge \varepsilon$ & $0 ., \cdot$ & 94 & 19,7 & די & $r \cdot, \varepsilon$ & 07 & الخوف من الموت من المرض. \\
\hline $1 \ldots$ & $1 \wedge \varepsilon$ & $r \wedge, r$ & or & $r \Lambda, r$ & or & $\varepsilon r, 0$ & A. & 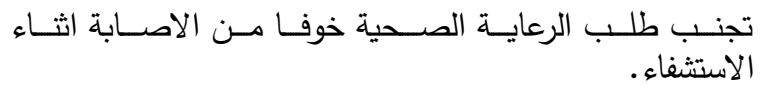 \\
\hline $1 \cdots$ & $1 \wedge \varepsilon$ & $r \wedge, r$ & or & 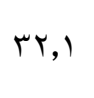 & 09 & ५ १, & $v r$ & أنها أعراض بين الاعراض كورونائعة للمشكلات الصحية الأخرى على \\
\hline $1 \cdots$ & $1 \wedge \varepsilon$ & rr, & 09 & $r \leqslant, \Lambda$ & $7 \leq$ & r & 71 & التوتر والثعور بالحرمان من رؤية الاهل والاصدقاء. \\
\hline $1 \cdots$ & $1 \wedge \varepsilon$ & $r V, r$ & o. & $r$ r & $\varepsilon r$ & $\leq 9,0$ & 91 & الخستقبل. مـن المجهـول الــي يحمـل وبـاء كوفيـــ - 19 فـي \\
\hline $1 \cdots$ & $1 \wedge \varepsilon$ & $77, \wedge$ & Irt & - & - & rT, & 71 & الخوف من فقدان الوظيفة. \\
\hline $1 \cdots$ & $1 \wedge \varepsilon$ & $\varepsilon r, 9$ & $\vee q$ & $r, r$ & $\varepsilon$ & $r \varepsilon, \Lambda$ & $7 \varepsilon$ & الشعور بالقلق والخوف مما يخبئه المستقبل من أحداث. \\
\hline
\end{tabular}


جدول ؛ ا. ـ دلالة الفروق بين متوسطات درجات افراد العينة في الوعي بأسباب وأعراض الاصابة بالمرض والوعي بالتدابير الوقائية وفقاُ للجنس - الحالة الاجتماعية- وجود أبناء بالأسرة

\begin{tabular}{|c|c|c|c|c|}
\hline \multirow[t]{2}{*}{ قيمة " ت " } & \multicolumn{2}{|c|}{ المتوسط والانحراف المعياري } & \multirow{2}{*}{ تبعاُ للجنس } & \\
\hline & إناث (ن & ذكور (ن= r T") & & \\
\hline$\curlyvee, \wedge \varepsilon-* *$ & $0, Y \vee \pm V Y, T)$ & $\vee, \cdot r \pm 7 q, 9 \wedge$ & أسباب وأعراض الفيروس & \\
\hline $1, r v-$ & $r, V \vee \pm r o, \cdot r$ & $r, T \cdot \pm r<, \varepsilon 0$ & النظافة الشخصية & $\overline{ }$ \\
\hline$\cdot, 0 \leqslant-$ & $\varepsilon, \Sigma) \pm \varepsilon \wedge, \wedge q$ & $\leqslant, 90 \pm \leqslant \wedge, 0$. & التسوق الآمن والتجمعات & $\frac{1}{7}$ \\
\hline$\cdot, \vee \leqslant-$ & $r, q \wedge \pm r \leqslant, r$. & $\varepsilon, Y \wedge \pm r r, \wedge r$ & بيئة العمل والمواصلات & $\overline{\bar{s}}$ \\
\hline$\cdot, 9 \cdot-$ & $|\cdot, \Sigma| \pm|| \wedge, Y \mid$ & $1 \cdot, 11 \pm 117, \vee V$ & الوعي بالتدابير الوقائية ككل & प्रु: \\
\hline \multirow{2}{*}{$1,99-*$} & $\mid r, r r \pm 19 \cdot, N r$ & $1 \varepsilon, \varepsilon \Gamma \pm \mid \wedge \neg, \vee ฯ$ & إجمالي الوعي & \\
\hline & متزوج (ن=| ا II) & غير متزوج (ن=ror) & تبعاً للحالة الاجتماعية & \\
\hline $1, V \vee-$ & $0,0 V \pm V Y, Y Y$ & \urcorner$, 97 \pm V \cdot, \varepsilon q$ & أسباب وأعراض الفيروس & \\
\hline$\cdot, 07-$ & $r, \vee \wedge \pm r<, q 1$ & $r, T \cdot \pm r \varepsilon, 74$ & النظافة الشخصية & 司 \\
\hline $1, \times 1-$ & $r, q r \pm \leqslant q, 1 r$ & $0, \wedge \vee \pm \leqslant \vee, \wedge 0$ & التسوق الآمن والتجمعات & $\frac{1}{2}$ \\
\hline $1, r v-$ & $r, \uparrow \wedge \pm r \varepsilon, \varepsilon$. & $\varepsilon, q) \pm r r, \varepsilon q$ & بيئة العمل والمواصلات & Ђ \\
\hline $1, \leqslant 0-$ & $9, \varepsilon r \pm 1) \wedge, \varepsilon r$ & $1 r, 10 \pm 117, \ldots$ & الوعي بالتدابير الوقائية ككل & : \\
\hline \multirow[t]{2}{*}{$1,90-*$} & $1 r, 1 r \pm 19 \cdot, 70$ & $10, \curlyvee \wedge \pm 1 \wedge 7, \leqslant 9$ & إجمالي الوعي & \\
\hline & لا يوجد (ن=9 & يوجد (ن=0 1 1 ) & تبعاً لوجود أبناء بالأسرة & \\
\hline $1, \leqslant 9$ & \urcorner$, 0 \wedge \pm V \cdot, \wedge V$ & $0,70 \pm V Y, Y T$ & أسباب وأعراض الفيروس & \\
\hline $1, v r$ & $r, v \leqslant \pm r \leqslant, q r$ & $1, \wedge \leq \pm r_{0}, 1$. & النظافة الشخصية & 司 \\
\hline$r, \cdot \Lambda *$ & $\uparrow, 11 \pm \leqslant \vee, \wedge \uparrow$ & $r, r \vee \pm \leqslant q, r$. & التسوق الآمن والتجمعات & $\frac{7}{7}$ \\
\hline 1,01 & $0,11 \pm r r, 00$ & $r, r q \pm r \leqslant, \varepsilon q$ & بيئة العمل والمواصلات & $\overline{5}$ \\
\hline $1,91 *$ & $1 T, v \leq \pm 110, \Lambda$ & $\vee, r V \pm 1) \wedge, \wedge q$ & الوعي بالتدابير الوقائية ككل & "권: \\
\hline$r, Y \leq *$ & $|7, \Sigma| \pm \mid \wedge 7,7 \vee$ & $1 \cdot, 0 \wedge \pm 191,1 \mathrm{r}$ & إجمالي الوعي & \\
\hline
\end{tabular}

al(2020) حيث وُجد أن الإناث أكثر وعياً من الذكور بفيروس كورونا المستجد، وقد يرجع ذلك إلى أن الإناث لديهن

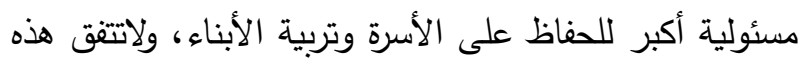

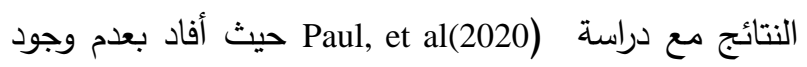

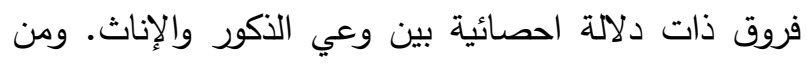

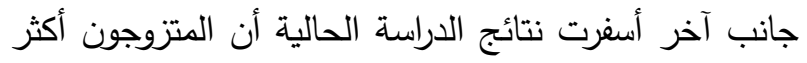

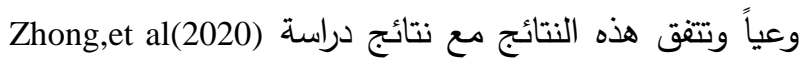
والتي أوضحت بأن المتزوجين كانوا أكثر وعياً من الأفراد

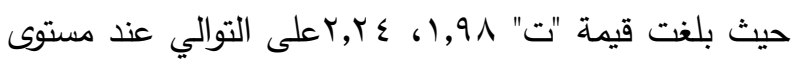
معنوية ه .,.، ولكن وُجدت فروق معنوية في الوعي بالتدابير

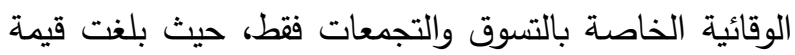

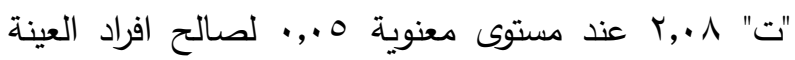
الذين لايهم أبناء بأسرهم، وتثير نتائج الدراسة بأن الإناث

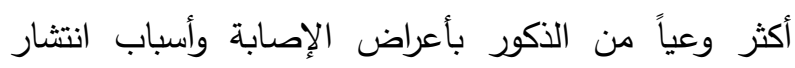

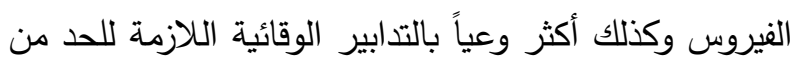

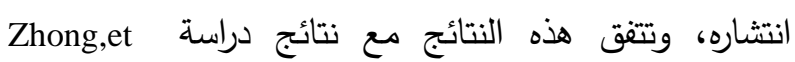


غير المتزوجين، وبذلك دعمت هذه النتائج عدم صحة الوقائية أكثر من الذكور، كما أفاد جمال الدين حسن

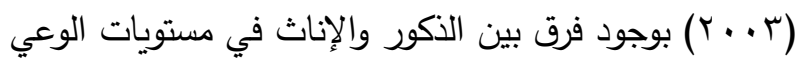
الفرض الأول جزئياً.

الصحي بصفة عامة لصالح الإناث، وبذلك تُدعم هذه النتائج

عدم صحة الفرض الثاني جزئياً.

الفرض الثالث: ينص هذا الفرض على أنه "لا يوجد فروق معنوية بين نوع الجنس والحالة الاجتماعية ووجود أبناء، وكل من الآثار النفسية والاجتماعية الناتجة عن البقاء بالمنزل خلال فترة الحظر المنزلي والعوائق التي تواجه عينة الدراسة في اتباع التدابير الوقائية" أفادت النتائج البحثية جدول (7 ( ) عدم وجود فروق معنوية بين كل من نوع الجنس والحالة الاجتماعية ووجود أبناء وكل من الآثار النفسية والاجتماعية الناتجة عن البقاء بالمنزل خلال فترة الحظر المنزلي والعوائق التي تواجه عينة الدراسة في اتباع التدابير الوقائية، ولذلك يُقبل الغرض الثالث كلياً.
الفرض الثاني: ينص هذا الفرض على أنه "لا يوجد فروق معنوية بين كل من نوع الجنس والحالة الاجتماعية ووجود أبناء فيما يختص باتباع التدابير الوقائية"، أوضحت النتائج البحثية جدول (0) وجود فروق معنوية بين متوسط درجات الذكور والإناث في اتباع التدابير الوقائية الخاصة بالنظافة الثخصية وبيئة العمل والمواصلات لصالح الإناث، حيث

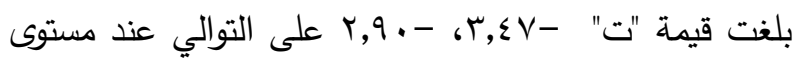
معنوية ا .,.,. 1.,., . على التوالي، كذلك وجدت فروق معنوية بين متوسط درجات الذكور والإناث في التزامهم باتباع التدابير الوقائية ككل للحد من انتشار الفيروس لصالح الإناث، حيث بلغت قيمة "ت" - ب, Y عند مستوى معنوية 1.,.، وتتقق هذه النتائج مع ما أسفرت عنه نتائج دراسة Retnaningsih,et al (2020) بشكل أفضل في منع انتقال مرض كوفيد ـو 19 واتباع التدابير

جدول ه ا. دلالة الفروق بين متوسطات درجات افراد العينة في اتباع التدابير الوقائية وفقاُ للجنس - الحالـة الاجتماعية وجود أبناء بالأسرة

\begin{tabular}{|c|c|c|c|}
\hline \multirow[t]{2}{*}{ قيمة " ت " } & \multicolumn{2}{|c|}{ المتوسط والانحراف المعياري } & \multirow{2}{*}{ تبعاً للجنس التدابر الوقائية } \\
\hline & إناث (ن & ذكور (ن= r & \\
\hline ऍ,乏マ-**** & $\varepsilon, r r \pm r 1,7 q$ & $7, r T \pm Y \wedge, q \leq$ & النظافة الثخصية \\
\hline $1, \wedge \cdot-$ & $q, 1) \sim \pm r q, \vee q$ & $9,7 \tau \pm r \vee, 1 \wedge$ & التسوق الآمن والتجمعات \\
\hline r,q.-*** & $\Upsilon, \Upsilon \wedge \pm Y \vee, \varepsilon$. & $\vee, Y \wedge \pm Y \leqslant, Y q$ & بيئة العمل والمواصلات \\
\hline \multirow[t]{2}{*}{ Y,AYー*** } & $1 \wedge, 1 \Gamma \pm 9 \wedge, \wedge \wedge$ & r $, r q \pm q \cdot, \varepsilon$. & اتباع التدابير الوقائية ككل \\
\hline & متزوج (ن=|r| & غير متزوج (ن=rم) & تبعاً للحالة الاجتماعية \\
\hline., .0 & $0, r u \pm r \cdot, v_{0}$ & $\varepsilon, 90 \pm r \cdot, \vee \vee q$ & النظافة الثخصية \\
\hline$\cdot, V \vee-$ & $q, 7) \pm r q, r \varepsilon$ & $\Lambda, \vee \vee \pm \Upsilon \wedge, \cdot \Lambda$ & التسوق الآمن والتجمعات \\
\hline $1, \cdot \wedge-$ & $V, \mid r \pm Y \tau, V)$ & $\Upsilon, Y \Delta \pm Y 0, \Sigma \vee$ & بيئة العمل والمواصلات \\
\hline \multirow[t]{2}{*}{$\cdot, \vee \vee-$} & $r \cdot, r\urcorner \pm 7 q, \vee$. & $\vee \vee, v \cdot \pm q \leq, r \leq$ & اتباع التدابير الوقائية ككل \\
\hline & لا يوجد (ن=9 ؟) & يوجد (ن=0 1 & تبعاً لوجود أبناء بالأسرة \\
\hline $1, Y \leq-$ & $\varepsilon, T 0 \pm \Gamma, r \wedge$ & $0,0 \leq \pm r \cdot, r q$ & النظافة الثخصية \\
\hline ., Ir & $৭, \Upsilon \wedge \pm \Gamma \wedge, \wedge$. & $৭, \Sigma \neg \pm r \wedge, q \vee$ & التسوق الآمن والتجمعات \\
\hline., $0 \mathrm{~V}$ & $v, \cdot \leq \pm r 0,9 \vee$ & $V, \cdot r \pm r r, O \Lambda$ & بيئة العمل والمواصلات \\
\hline$\cdot, \cdot V$ & $11,0 \cdot \pm 97,1 \leq$ & $r \cdot, r r \pm 90,90$ & اتباع التدابير الوقائية ككل \\
\hline
\end{tabular}




$$
\text { مجلة الإسكندرية للتبادل العلمى - (مجلدrع العدد () يناير - مارس Ir.r }
$$

جدول 17 ـ دلالـة الفروق بين متوسطات درجات افراد العينـة بالنسبة للآثار النفسية والاجتماعية وعوائق اتباع التدابير الوقائية وفقاُ للجنس - الحالة الاجتماعية - وجود أبناء بالأسرة

\begin{tabular}{|c|c|c|c|}
\hline \multirow[t]{2}{*}{ قيمة "ت" } & \multicolumn{2}{|c|}{ المتوسط والانحراف المعياري } & الآثار و العوائق \\
\hline & إناث (ن Y r Y ( ) & ذكور (ن= & تبعاً للجنس \\
\hline$\cdots r-$ & $\tau . V \cdot \pm r \varepsilon . V T$ & T. $\varepsilon \leqslant \pm Y \varepsilon . V \varepsilon$ & الآثار النفسية والاجتماعية \\
\hline..$\times 9$ & $1.1 r \pm 9.10$ & $1.11 \pm 9.9 \leq$ & عوائق اتباع التدابير الوقائية \\
\hline & متزوج (ن=| ITI) & غير متزوج (ن=rOH) & تبعاً للحالة الاجتماعية \\
\hline $1.1 \varepsilon$ & T. YYIY $\varepsilon . \varepsilon$. & $V . \varepsilon r \pm r 0 . T r$ & الآثار النفسية والاجتماعية \\
\hline T.乏^ & $1 . V \cdot \pm 9.7 V$ & 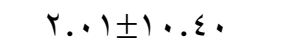 & عوائق اتباع التدابير الوقائية \\
\hline & لا يوجد (ن=99) & يوجد (ن=0 ا 11$)$ & تبعاً لوجود أبناء بالأسرة \\
\hline $1.11-$ & $V . T \cdot \pm Y_{0} . \leqslant 0$ & $0.91 \pm r \varepsilon . r \varepsilon$ & الآثار النفسية والاجتماعية \\
\hline Y.乏.- & $1.97 \pm 1 . .19$ & $1.79 \pm 9.71$ & عوائق اتباع التدابير الوقائية \\
\hline
\end{tabular}

اسفرت نتائج جدول(1/1) عدم وجود علاقة ارتباطية معنوية بين كل من السن وعدد سنوات العمل واتباع التدابير

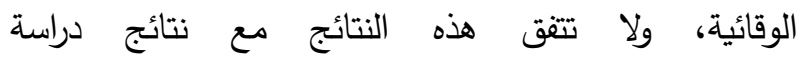
حيث وجدوا أن Paul,et al(2020)، Rahman,et al (2020) افراد العينة الأكبر سناً والتي تراوحت أعمارهم من (דب 0؟ سنة كانوا أكثر وعياً ودراية بكوفيد -9 19 من افراد العينة

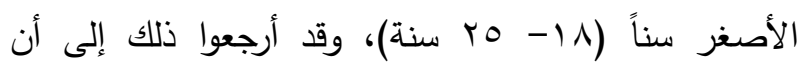
الثباب قد يثعرون بأنهم أقل عرضة للإصابة بالفيروس وفقاً لما ذكرته منظمة الصحة العالمية مقارنة بكبار السن، في

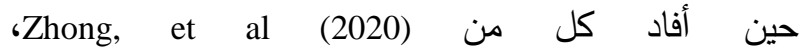
Abdelhafiz,et al (2020) العينة الذين تراوحت أعمارهم من ( •-0- . ؟7) عاماً أقل وعياً

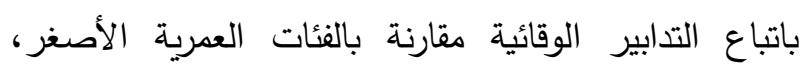
وبذلك يُقبل الفرض الخامس كلياً.
الفرض الرابع: ينص هذا الفرض على أنه "لا توجد علاقة ارتباطية معنوية بين السن وعدد سنوات العمل، وكل من الوعي بأسباب وأعراض فيروس كورونا المستجد والوعي بالتدابير الوقائية الواجب اتباعها"، أوضحت نتائج جدول وجود علاقة ارتباطية طردية معنوية بين وعي افراد (IV)

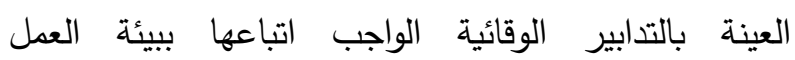
والمواصلات العامة كمتغير تابع وبين عدد سنوات العمل، حيث بلغت قيمة معامل الارتباط V إ , , وذلك عند مستوى معنوية ه ., •، وبذلك تُدعم هذه النتائج عدم صحة الفرض الرابع جزئياً. الفرض الخامس: ينص هذا الفرض على أنه "لا توجد علاقة ارتباطية معنوية بين كل من السن وعدد سنوات العمل، واتباع التدابير الوقائية".

جدول V ا. قيم معامل الارتباط بين السن وعدد سنوات العمل وكل من الوعي بأسباب واعراض الاصسابة بالفيروس واللوعي بالتدابير الوقائية

\begin{tabular}{|c|c|c|c|c|c|c|}
\hline \multicolumn{6}{|c|}{ الوعي } & \multirow[t]{3}{*}{ المتغيرات التابعة } \\
\hline \multirow[b]{2}{*}{ الجوعالي } & \multicolumn{4}{|c|}{ الوعي بالتدابير الوقائية } & & \\
\hline & الوقُائية بالتدلير & وآلمواصئة العلات & التسوق الآتمعات & الثخصية النظافة & الاصنبة الفيروس & \\
\hline$\cdot, \cdot \wedge r$ & $\cdot, 1 \cdot r$ & $\cdot, 11 \mathrm{~V}$ &., $.0 Y$ & $\cdot, 1 Y \leq$ & $\bullet, \cdots \wedge$ & السن \\
\hline r &., 117 & $\cdot, 1 \leqslant V^{*}$ & .,.Or & سזו, & ., 1 1 & عدد سنوات العمل \\
\hline
\end{tabular}


جدول 11. قيم معامل الارتباط بين العن وعدد سنوات العمل واتباع التدابير الوقائية

\begin{tabular}{|c|c|c|c|c|}
\hline \multicolumn{4}{|c|}{ اتباع التدابير الوقائية } & \multirow{2}{*}{ المتغيرات التابعة } \\
\hline التوقائية ككلبير & اتباع تدابير بيئة العمل & التسوق والتجمبعات & اتباع تدابير النظافة & \\
\hline ,., ro- & .,. Ү৭- & $\cdot, \cdot \leq r-$ & ., , Yr & 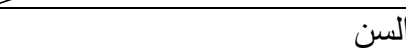 \\
\hline$\cdot, \cdot 9 r-$ & , I.r- & $\cdot, \cdot \wedge 1-$ & - & عدد سنوات العمل \\
\hline
\end{tabular}

(ץ) وجود علاقة ارتباطية معنوية بين كل من التزام افراد العينة باتباع التدابير الوقائية ووعيهم بهذه التدابير الوقائية

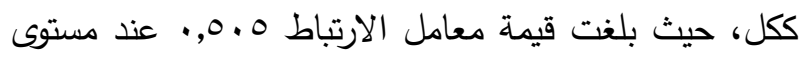

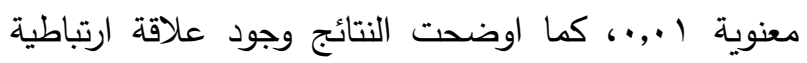
معنوية بين كل من التزام افراد العينة باتباع التدابير الوقائية

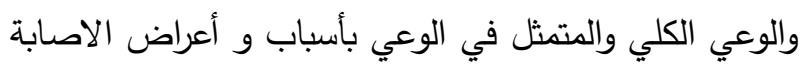

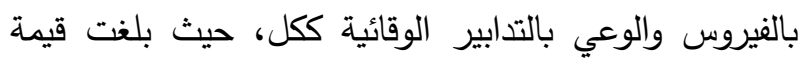

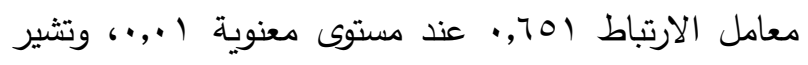

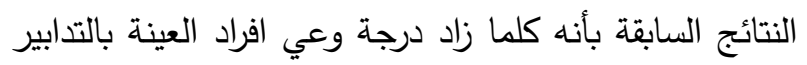
الوقائية كلما زاد مستوى الالتزام باتباع هذه التدابير وهذا بانها

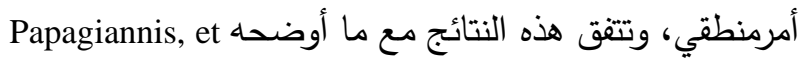
al(2020) بأن الأفراد ذوي الوعي المرتفع أظهروا ممارسات

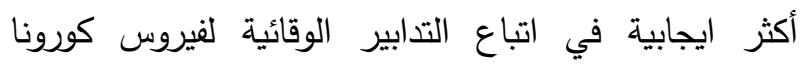
المستجد، وتُدعم هذه النتائج عدم قبول الفرض التبر السابع كلياً.
الفرض السادس: ينص هذا الفرض على أنه "لا توجد علاقة

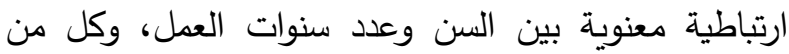
الآثار النفسية والاجتماعية الناتجة عن البقاء بالمنزل خلال

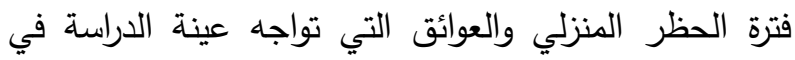

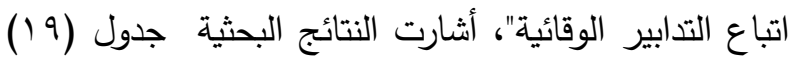

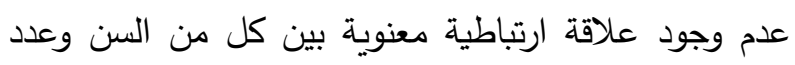
سنوات العمل، والآثار النفسية والاجتماعية الناتجة عن البقاء بالمنزل خلال فترة الحظر المنزلي والعوائق التي تواجه عينة

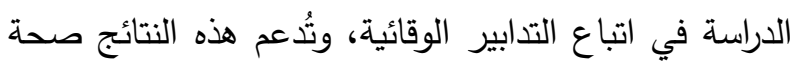
الفرض وبذلك يقبل الفرض السادس كلياً. الفرض السابع: ينص هذا الفرض على أنه "لا توجد علاقة

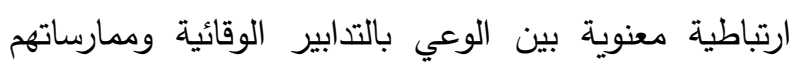

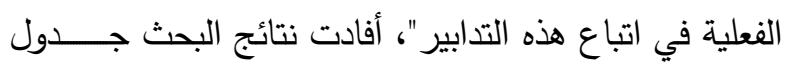

جدول 9 ـ قيم معامل الارتباط بين السن وعدد سنوات العمل والآثار النفسية والاجتماعية خلال فترة الحظر وعوائق اتباع التدابير الوقائية

\begin{tabular}{|c|c|c|}
\hline \multicolumn{2}{|c|}{ الآثار النفسية والاجتماعية خلال فترة الحظر وعوائق اتباع التدابير } & المتغيرات التابعة \\
\hline عوائق اتباع التدابير & آثار الحظر المنزلي & المتغيرات المستقلة \\
\hline$\cdot, \cdot \Gamma \wedge$ & 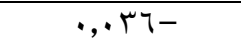 & السن \\
\hline.,$\ldots \leqslant$ & ., 1. & عدد سنوات العمل \\
\hline
\end{tabular}

جدول · r. العلاقة الارتباطية بين الوعي بالتدابير الوقائية واتباع هذه التدابير

\begin{tabular}{|c|c|c|c|c|c|c|}
\hline \multicolumn{6}{|c|}{ الوعي } & \multirow{3}{*}{ المتغيرات التابعة } \\
\hline \multirow{2}{*}{ ألجوعيالي } & & ير الوقائية & الوعي با & & \multirow[b]{2}{*}{ الاصنبابة وأعيراض } & \\
\hline & الوقعي بالتئلير ككل & والثيئة العلات & التسوق الآمن & الثخصية & & \\
\hline$\cdot, 701 * *$ & $\cdot, 0.0 * *$ & 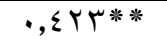 & $\cdot, \sum \curlyvee \Lambda^{* * *}$ & ,,$\Sigma 9 Y^{* * *}$ & •,07个*** & اتباع التدابير الوقائية \\
\hline
\end{tabular}


، حيث اتضح وجود فروق معنوية بين متوسطات الوعي الكلي والمستويات التعليمية المختلفة لأفراد العينة، وقد ثبت معنويتها لصالح الأفراد الحاصلين على مؤهل جامعي وهو أعلى متوسط حيث بلغ 190,0 1 عند مستوى معنوية ه .... Li, et al (2020), وتتفق هذه النتائج مع نتائج دراسة Rahman,et al(2020) الحاصلين على تعليم جامعي يتمتعون بوعي أعلى من الأفراد الحاصلين على مؤهلات تعليمية أقل.
الفرض الثامن: ينص هذا الفرض على أنه "لا يوجد تباين معنوي بين التعليم ومتوسط الاخل، وكل من الوعي بأسباب وأعراض فيروس كورونا المستجد والوعي بالتدابير الوقائية الواجب اتباعها"، بدراسة العلاقة بين الوعي الكلي والمستوى التعليمي لأفراد العينة، أشارت النتائج البحثية جدول (Y) الى وجود تباين معنوي حيث بلغت قيمة "ف" آ7,7 آوهي قيمة معنوية عند مستوى احتمالي ا (.... . ولتوضيح طبيعة الفروق المعنوية في نتائج تحليل التباين تم إجراء اختبار LSD

جدول اب. قيمة "فـ" لتحليل التباين ANOVA في اتجاه واحد والمتوسط الحسابي والانحراف المعياري ومعنويـة الفروق بين المتوسطات(LSD) للوعي بالتدابير الوقائية لأفراد العينة تبعا لمستوى التعليم

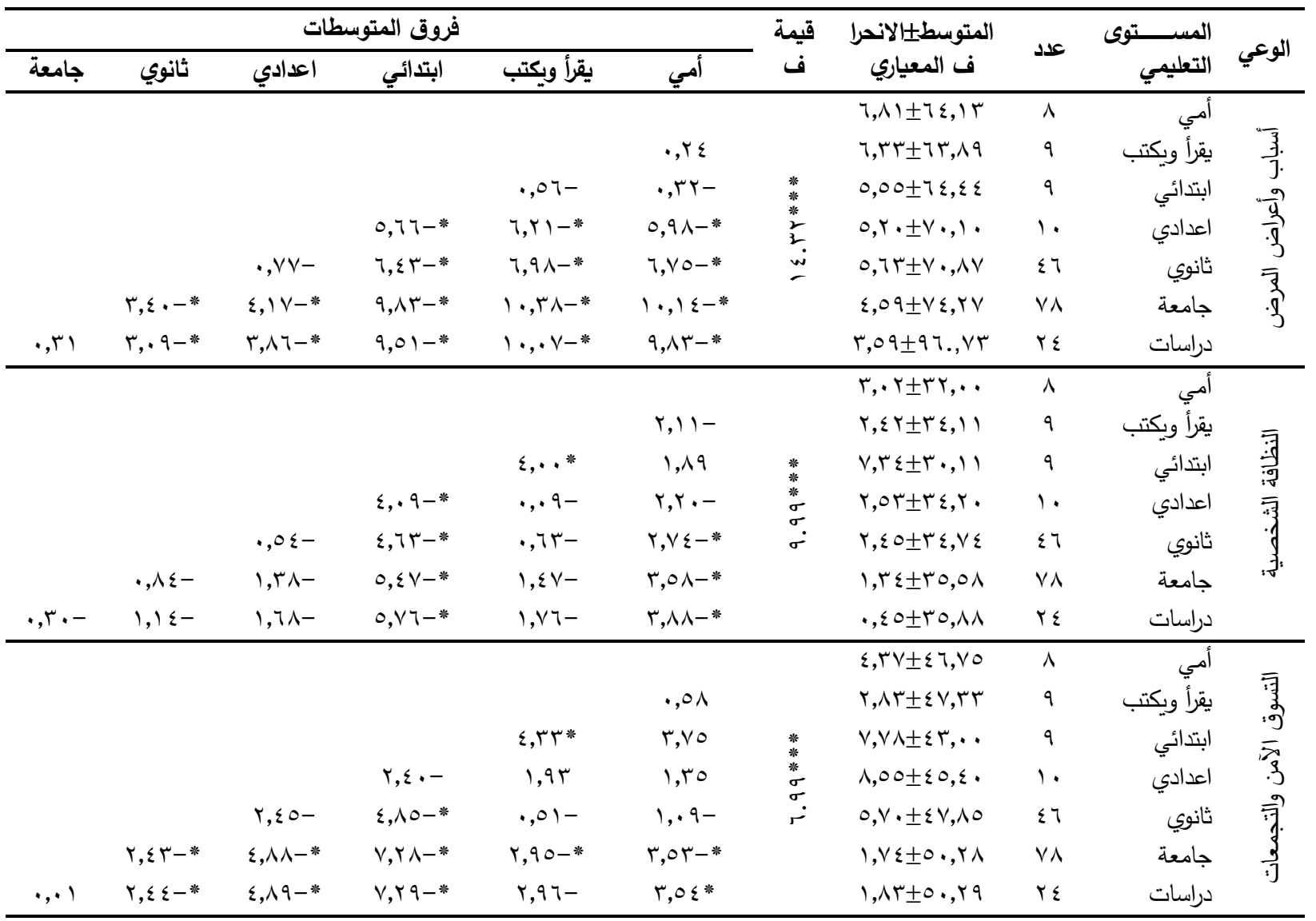


تابع جدول ا r. قيمة "فـ" لتحليل التباين ANOVA في اتجاه واحد والمتوسط الحسابي والانحراف المعياري ومعنوية الفروق

بين المتوسطات(LSD) للوعي بالتدابير الوقائية لأفراد العينة تبعا لمستوى التعليم

\begin{tabular}{|c|c|c|c|c|c|c|c|c|c|c|}
\hline \multicolumn{6}{|c|}{ فروق المتوسطات } & \multirow{2}{*}{ قيمة } & \multirow{2}{*}{ المتوسطدالانحراف } & \multirow{2}{*}{ عدد } & \multirow{2}{*}{ التمستوى التعليمي } & \multirow{2}{*}{ الوعي } \\
\hline جامعة & ثانوي & اعدادي & ابتدائي & يقرأ ويكتب & أمي & & & & & \\
\hline & & & & & & & $\varepsilon, T \pm \pm r \uparrow, O$ & $\wedge$ & أمي & \\
\hline & & & & & $1, .7-$ & & $r, I V \pm r r, 0 T$ & 9 & يقرأ ويكتب & 承 \\
\hline & & & & $r, \tau \vee *$ & $r, T)$ & $*$ & $\curlyvee, \wedge \neg \pm \Upsilon \uparrow, \wedge q$ & 9 & ابتدائي & $\overline{3}$ \\
\hline & & & $r, 11-$ & 1,07 &., 0 & $\stackrel{*}{\alpha}$ & $\varepsilon, r \cdot \pm r r, \ldots$ & 1. & اعدادي & दे \\
\hline & & I,r.- & $r, \Sigma \Upsilon-*$ & , ro & $\cdot, \wedge \cdot-$ & w & $0, r \leqslant \pm r r, r$. & $\leq 7$ & ثانوي & S \\
\hline & $r, .9-*$ & $\Gamma, \varepsilon \cdot-*$ & $0,01-*$ & I,^ $\varepsilon-$ & r,q.-** & & $r, 0 r \pm r o, \varepsilon$. & vi & جامعة & 雹 \\
\hline \multirow[t]{7}{*}{.,Or } & $1,0 \mathrm{~V}-$ & $r, \wedge \Lambda-*$ & $\varepsilon, 99-*$ & I,rr- & $r, r \wedge-$ & & $r, \varepsilon \neg \pm r \leqslant, \wedge \Lambda$ & $r \varepsilon$ & دراسات & \\
\hline & & & & & & & $11, r v \pm \|, r_{0}$ & $\wedge$ & أمي & \\
\hline & & & & & r,vo- & & $V, r \circ \pm 110, \ldots$ & 9 & يقرأ ويكتب & \\
\hline & & & & $k, \ldots *$ & $\Lambda, r_{0}$ & $*$ & $r \backslash, \uparrow \wedge \pm 1 \cdot r, \ldots$ & 9 & ابتدائي & 寻 \\
\hline & & & $\Lambda, 7 \cdot-* *$ & r, . . & - & $\frac{*}{\sigma}$ & $|r, r| \pm 111, r$ & 1. & اعدادي & \\
\hline & & $\varepsilon, r q-$ & ২ Ү,^৭* & $\cdot, \wedge 9-$ & $\varepsilon, 7 \leqslant-$ & $>$ & $\mid r, r q \pm 110, \wedge q$ & $\leq 7$ & ثانوي & . \\
\hline & $0, r v-*$ & $9,77-*$ & $1 \wedge, \Upsilon \uparrow *$ & $7, Y 7-$ & $1 \cdot, \cdot 1-*$ & & $\{, 0 V \pm|r|, r \Psi$ & $\vee \wedge$ & جامعة & $\underline{y}$ \\
\hline \multirow[t]{7}{*}{, rr } & $0,10-*$ & $9, \Sigma \leqslant-*$ & $11, \cdot \leq *$ & $7, \cdot \leq-$ & $৭, \vee १-*$ & & $\varepsilon, \cdot \wedge \pm|r|, \cdot \varepsilon$ & $r \leq$ & دراسات & \\
\hline & & & & & & & $|\varepsilon, \Lambda| \pm \mid \vee 0, r \wedge$ & $\wedge$ & أمي & \\
\hline & & & & & $r, 01-$ & & $\wedge, \neg \curlyvee \pm ו \vee \wedge, \wedge q$ & 9 & يقراً ويكتب & \\
\hline & & & & $11, \leq \varepsilon$ & V,qr & $*$ & $19, \cdot r \pm 1 T V, \varepsilon \varepsilon$ & 9 & ابتدائي & ja: \\
\hline & & & 1 $\{, Y 7-*$ & r,A - & 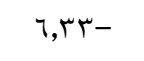 & $\frac{*}{r}$ & $10, r r \pm|\wedge|, \mathrm{r}$. & 1. & اعدادي & $\begin{array}{l}\text { y. } \\
\overline{2}\end{array}$ \\
\hline & & $0, \cdot 7-$ & $19, r r-*$ & $\vee, \wedge \vee-*$ & $11, r q-*$ & 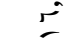 & $|\varepsilon, \cdots \pm| \wedge 4, \vee \uparrow 4$ & $\leq 7$ & ثانوي & y. \\
\hline & $\Lambda, \vee \vee-*$ & $\mid r, \wedge r-*$ & $\curlyvee \wedge, \cdot \wedge-*$ & $17,7 \leqslant-*$ & $r \cdot, 10-\%$ & & $\vee, r \wedge \pm 190,0 r$ & v^ & جامعة & \\
\hline ,or & $\Lambda, r \leq-*$ & $1 r, r \cdot-* *$ & $r V, 07-*$ & $17,11-*$ & $19,7 r-*$ & & $\{, r \backslash \pm 190, \ldots$ & $r \varepsilon$ & دراسات & \\
\hline
\end{tabular}

"مستوى معنوية 0 .,.

"مستوى معنوية 1, *,., *.,

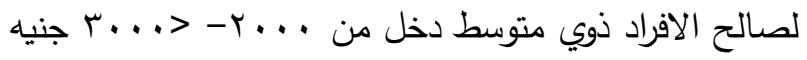

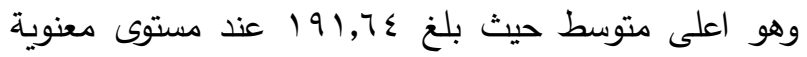

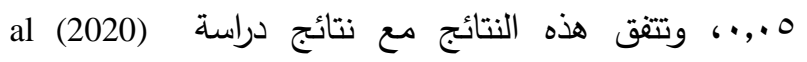
Abdelhafiz, et الدخل الثهري المنخفض لديهم وعي أقل بشكل ملحوظ

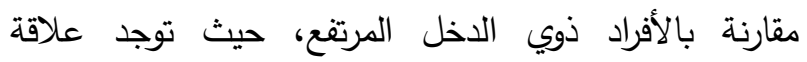
ارتباطية ايجابية بين مستوى الوعي ومستوى الدخل الثهري للأفراد، وتُدعم هذه النتائج عدم قبول الفرض الثاطه لثنامن جزئياً.
اوضحت النتائج البحثية جدول (rr) عدم وجود تباين معنوي بين متوسط الدخل والوعي بأسباب وأعراض الاصابة بفيروس كورونا المستجد، وبدراسة العلاقة بين الوعي الكلي ومتوسط الدخل الثهري لأفراد العينة، أوضحت النتائج البحثية بنفس الجدول وجود تباين معنوي حيث بلغت قيمة "ف" 99, T وهي قيمة معنوية عند مستوى احتمالي ه.,.•، ولتوضيح طبيعة الفروق المعنوية تم اجراء اختبار LSD، حيث اتضح وجود فروق معنوية بين متوسطات الوعي الكلي ومتوسط الدخل الثهري لأفراد العينة و قد ثبت معنويتها 
جدول r r . قيمة "ف" لتحليل التباين ANOVA في اتجاه واحد والمتوسط الحسابي والانحراف المعياري و معنوية الفروق بين المتوسطات( LSD ) للوعي بالتدابير الوقائية لأفراد العينة تبعا لمتوسط الدخل

\begin{tabular}{|c|c|c|c|c|c|c|}
\hline \multicolumn{2}{|c|}{ فروق المتوسطات } & \multirow{2}{*}{ قيمة ف } & \multirow{2}{*}{ المتوسطي|لانحراف } & \multirow{2}{*}{ عدد } & \multirow{2}{*}{ فئات الاخل } & \multirow{2}{*}{ ل ل لوعي } \\
\hline$r \ldots>-r \ldots$ & $r \ldots\rangle$ & & & & & \\
\hline \multirow[b]{3}{*}{$1,09-$} & & \multirow{3}{*}{$1, .7$} & $T, \cdot \Sigma \pm V \backslash, T r$ & OV & $r \ldots>$ & \multirow{3}{*}{ ألاصباب وأعراض بالفيروس } \\
\hline & $\cdot, V T$ & & $\neg, Y) \pm V Y, r q$ & $V V$ & $r \ldots>-r \ldots$ & \\
\hline & $\cdot, \wedge r$ & & $0, \vee r \pm \vee \cdot, \wedge$. & 0. & . . . . فأكثر & \\
\hline \multirow{6}{*}{$\cdot, \cdot \varepsilon-$} & & \multirow{3}{*}{$\vee, £ 0 * * *$} & $\varepsilon, \cdot V \pm T r, V Y$ & or & $r \ldots>$ & \multirow{3}{*}{ لنظافة الشخصية } \\
\hline & $1,71-*$ & & $1,00 \pm r_{0, r}$ & $V V$ & $r \ldots>-r \ldots$ & \\
\hline & $1,7 \leqslant-*$ & & $1, v \cdot \pm r 0, r u$ & 0 . & . . . . & \\
\hline & & \multirow{3}{*}{$\Gamma, 7) *$} & $0, \leqslant\rceil \pm \leqslant 7, \leqslant \varepsilon$ & OV & $r \ldots>$ & \multirow{3}{*}{ إلتجمعات الآمن } \\
\hline & $1, \vee \vee 7-*$ & & $\varepsilon, 17 \pm \leqslant 9,19$ & $V V$ & $r \ldots>-r \ldots$ & \\
\hline & $r, 1 \leqslant-*$ & & $r, \Lambda r \pm \sum q, ० \wedge$ & 0. & . . . سفأكثر & \\
\hline \multirow[t]{2}{*}{$\cdot, r q-$} & & & $0, \Lambda 0 \pm r Y, T V$ & or & $r \ldots>$ & \multirow{3}{*}{ والمواصيئة العملت } \\
\hline & r,, $7-*$ & $0,77 * *$ & $r, r \circ \pm r \varepsilon, V r$ & $V V$ & $r \ldots>-r_{\ldots}$. & \\
\hline \multirow[t]{3}{*}{$\cdot, \mid \vee-$} & $r, r M-* *$ & & $r, r \wedge \pm r \leqslant, q$. & 0 . & . . . . سأكثر & \\
\hline & & & $1 \varepsilon, 1 r \pm \|, r, \wedge r$ & ov & $r \ldots>$ & \multirow{3}{*}{ الوقائية ككل بالتدابير } \\
\hline & $0, \varepsilon r-*$ & $\Upsilon, \Gamma Y^{*} * *$ & \urcorner$, \vee \wedge \pm 1) 9, \Upsilon_{0}$ & V V & $r \ldots>-r \ldots$ & \\
\hline \multirow[t]{3}{*}{$\cdot, 09-$} & $T, \cdot r-*$ & & $\wedge, \varepsilon\rceil \pm 1) 9, \wedge \varepsilon$ & 0 . & . . . . سأكثر & \\
\hline & & & $|V, r| \pm \mid \wedge 0, \Sigma \neg$ & ov & $r \cdots>$ & \multirow{3}{*}{ إجمالي الوعي } \\
\hline & $\Upsilon, 1 \wedge-*$ & ५,१९* & $1 \cdot, 7 \cdot \pm 191,7 \leq$ & $V V$ & $r \ldots>-r \ldots$ & \\
\hline $1, \ldots$ & $0,11-*$ & & $1 \cdot, r 0 \pm 19 \cdot, 7 \leq$ & 0 . & . . . . فأكثر & \\
\hline
\end{tabular}

كما اوضحت النتائج البحثية جدول (؟ع) وجود تباين معنوي بين اتباع التدابير الوقائية ومتوسط الدخل الثهري،

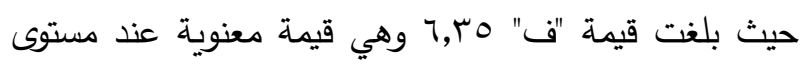
احتمالي ا +,.•، ولتوضيح طبيعة الفروق المعنوية تم اجراء اختبار LSD حيث اتضح وجود فروق معنوية بين متوسطات اتباع التدابير الوقائية ومتوسطات الدخل الثهري لأفراد العينة، وقد ثبت معنويتها لصالح الافراد ذوي متوسط دخل

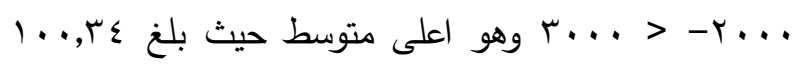
عند مستوى معنوية ه.,.، وتتفق هذه النتائج مع نتائج دراسة (Zhong,et al(2020 حيث أفاد بأن الأفراد ذوي المستوى الاجتماعي والاقتصادي الجيد يتمتعون بمستوى معرفة

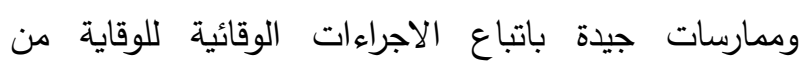

الفرض التاسع: ينص هذا الفرض على أنه "لا يوجد تباين معنوي بين كل من التعليم ومتوسط الدخل الثهري، واتباع

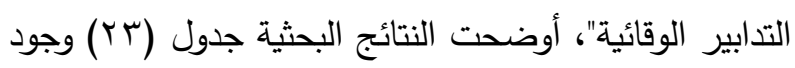
تباين معنوي بين اتباع التدابير الوقائية ككل والمستوى

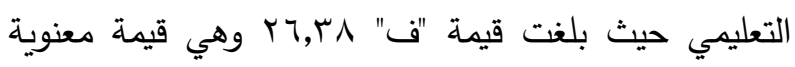
عند مستوى احتمالي ا +.,.، ولتوضيح طبيعة الفروق المعنوية تم إجراء اختبار LSD، حيث اتضح وجود فروق

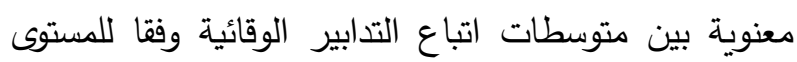
التعليمي، وقد ثبت معنويتها لصالح الحاصلين على مؤهلات

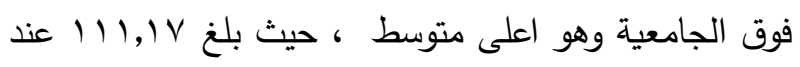
مستوى معنوية 0 .,.•. 
الإصابة بالفيروس، وتُعم هذه النتائج عدم قبول الفرض التاسع كلياً.

جدول بr . قيمة "ف" لتحليل التباين ANOVA في اتجاه واحد والمتوسط الحسابي والانحراف المعياري ومعنوية الفروق بين متوسطات (LSD) اتباع التدابير الوقائية لأفراد العينة تبعا لمستوى التعليم

\begin{tabular}{|c|c|c|c|c|c|c|c|c|c|c|}
\hline \multicolumn{6}{|c|}{ فروق المتوسطات } & \multirow{2}{*}{ قيمة } & \multirow{2}{*}{ المتوسط土 الانحراف } & \multirow[t]{2}{*}{ عدد } & \multirow{2}{*}{ التعليميــتوى } & \multirow{2}{*}{ التباعبيز } \\
\hline جامعة & ثانوي & اعدادي & ابتدائي & يقرأ ويكتب & أمي & & & & & \\
\hline & & & & & & & $7,97 \pm r r, r_{0}$ & $\wedge$ & & \\
\hline & & & & & $1, Y_{0}$ & & $\varepsilon, T \leqslant \pm Y r, \ldots$ & 9 & يقرأ ويكتب & \\
\hline & & & & $\cdot, \wedge 9-$ & דוז, & $\begin{array}{l}* \\
*\end{array}$ & $0, \cdot 1 \pm r r, \wedge q$ & 9 & & \\
\hline & & & $r, q 1-$ & 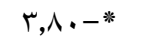 & Y,00- & $\stackrel{*}{*}$ & $r, 19 \pm r 0, \wedge$. & 1. & اعدادي & 可 \\
\hline & & (r, & $V, Y \leq-*$ & $\wedge, 1 \Gamma^{*}$ & \urcorner,$\wedge \wedge-*$ & $i$ & سו, & $\varepsilon\rceil$ & ثانوي & \\
\hline & ५, ५ १-* & V,TYー* & $1 \cdot, 0 r-*$ & $11, \cdot \varepsilon-*$ & $1 \cdot, 1 \vee-*$ & & $r, q \wedge \pm r r, \Sigma r$ & VA & جامعة & \\
\hline \multirow[t]{7}{*}{$\cdot, V \cdot-$} & $\varepsilon, \ldots-*$ & 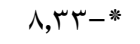 & $11, r \leq-*$ & $|r| r-*$, & $1 \cdot, \wedge \wedge-$ & & $r, O r \pm r \leq, 1 T$ & $r \leq$ & دراسات & \\
\hline & & & & & & & $1.01 \pm \pi 1,1 \pi$ & $\wedge$ & & \\
\hline & & & & & $\varepsilon, \cdot 1$ & & $r, r \circ \pm r v, 11$ & 9 & ويكتب & (ब' \\
\hline & & & & $\cdot, \wedge 9$ & $\varepsilon, q$. & * & $0, \varepsilon r \pm Y \nearrow, Y r$ & 9 & & \\
\hline & & & $0, \wedge \wedge-$ & $\varepsilon, 99-$ & $\cdot, 9 \wedge-$ & $z^{*}$ & \urcorner$, 7 q \pm r r, 1$. & 1. & اعدادي & \\
\hline & & $\varepsilon, \varepsilon Y-$ & 1., & $9, \Sigma)-*$ & $0, \varepsilon \cdot-$ & $\underline{\Sigma}$ & $V, 97 \pm r 7, O r$ & $\leqslant\rceil$ & ثانوي & \\
\hline & $7, \curlywedge \wedge-*$ & $\mid \cdot, 71-*$ & $17, \leqslant \wedge-*$ & $10,09-*$ & $11,01-*$ & & $V, O V \pm \leqslant Y, V)$ & $\vee \wedge$ & جامعة & \\
\hline \multirow[t]{7}{*}{$r, .0-$} & $9, r r-*$ & $1 \%, 70-*$ & $19,0 \mathrm{m-*}$ & $1 \wedge, 7 \leq-*$ & I乏,Tr-* & & $T, Y Y \pm \leqslant 0, V_{0}$ & $r \varepsilon$ & دراسات & \\
\hline & & & & & & & $V, O r \pm Y r, I r$ & $\wedge$ & & \\
\hline & & & & & $0,1 T$ & & $\Gamma, r q \pm) \wedge, \ldots$ & 9 & | ويكتب & \\
\hline & & & & $\cdot, Y r$ & 0, L & $*$ & $r, \Sigma q \pm) \vee, \vee \wedge$ & 9 & & 3 \\
\hline & & & T,rY- & $r, 1 \cdot-$ & $r, \cdot r$ & * & $7, r \leq \pm r 1,1$. & 1. & اعدادي & ने \\
\hline & & r,vq- & $\vee, 11-*$ & \urcorner,$\wedge ৭-*$ & $1, \vee \vee-$ & 2 & $\neg, T) \pm r \leqslant, \wedge 9$ & $\leqslant 7$ & ثانوي & 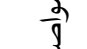 \\
\hline & 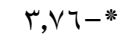 & $\vee, 00-*$ & $1 \cdot, \wedge \wedge-*$ & $1 \cdot, 70-*$ & 0,0 r-* & & $\neg, \cdots \pm r \wedge, \Upsilon_{0}$ & $\vee \wedge$ & جامعة & : \\
\hline \multirow[t]{7}{*}{$r, T \leq-$} & \urcorner,$\varepsilon \cdot-* *$ & $1 \cdot, 19-*$ & $\mid r, 01-*$ & $1 \Upsilon, Y 9-*$ & $\wedge, 1 \vee-*$ & & $0,1 r \pm r,, r q$ & $r \varepsilon$ & دراسات & \\
\hline & & & & & & & $r r, q r \pm V V, 0$. & $\wedge$ & & \\
\hline & & & & & $1 \cdot, r q$ & & $11, v \cdot \pm T \vee, 11$ & 9 & يقرأ ويكتب & f. \\
\hline & & & & $\cdot, Y Y$ & $\mid \cdot, 71$ & * & $9,00 \pm 77, \wedge 9$ & 9 & ابتدائي & \\
\hline & & & $\mid r, 11-$ & $11, \wedge 9-$ & $1,0 .-$ & $\stackrel{*}{2}$ & $1 \varepsilon, r \leqslant \pm \vee q, \ldots$ & 1. & اعدادي" & 再. \\
\hline & & $1, r, 0 \leq-*$ & 「ะ,フ ー** & $r \varepsilon, \varepsilon \Gamma-*$ & $1 \leq,+\varepsilon-*$ & 2 & $10,7 \leqslant \pm 91,0 \leqslant$ & $\varepsilon 7$ & ثانوي & 司 \\
\hline & $\mid r, Y \leq-*$ & Y०, $\vee \wedge-*$ & rv,^৭-* & rv,TV-* & イV,Y^ー* & & $\mid \varepsilon, \cdot r \pm 1 \cdot \varepsilon, \vee \wedge$ & $\vee \wedge$ & جامعة & $\bar{q}$ \\
\hline $7, r q-$ & $19,7 r-*$ & $r Y, \mid \vee-*$ & $\varepsilon \varepsilon, \Upsilon \wedge-*$ & $\varepsilon \varepsilon, \cdot\urcorner-*$ & & & $1 r, \cdot 1 \pm 111,1 \mathrm{~V}$ & $r \varepsilon$ & دراسات & \\
\hline
\end{tabular}


جدول ع r. قيمة "فـ" لتحليل التباين ANOVA في اتجاه واحد والمتوسط الحسابي والانحراف المعياري ومعنويـة الفروق بين متوسطات (LSD) اتباع التدابير الوقائية لأفراد العينة تبعا لمتوسط الاخل

\begin{tabular}{|c|c|c|c|c|c|c|}
\hline \multicolumn{2}{|c|}{ فروق المتوسطات } & \multirow{2}{*}{ قيمة ف } & \multirow{2}{*}{ المتوسطدالانحراف المعياري } & \multirow{2}{*}{ 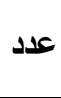 } & \multirow{2}{*}{ فئئات الاخل } & \multirow{2}{*}{ اتباع التدبير } \\
\hline$r \ldots>-r \ldots$ & $r \ldots\rangle$ & & & & & \\
\hline \multirow{5}{*}{$\cdot, 1 \cdot-$} & & \multirow{3}{*}{$0,0 Y * *$} & $0, Y \circ \pm Y \wedge, \wedge q$ & ov & $r \cdots>$ & \multirow{3}{*}{ الثخصية } \\
\hline & ґ,тฯ* & & $0,1 \leqslant \pm r_{1,07}$ & $\checkmark V$ & $r \ldots>-r \ldots$ & \\
\hline & $r, \nabla V^{*}$ & & $\varepsilon, \wedge 9 \pm r 1,74$ & 0 . & 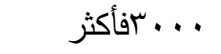 & \\
\hline & & \multirow{3}{*}{$0, Y \cdot * *$} & $\Lambda, ৭ 9 \pm r_{0, \nu_{0}}$ & ov & $r \ldots>$ & \multirow{3}{*}{ والتجمعات الآمن } \\
\hline & $0, \cdot \wedge^{*}$ & & $\Lambda, 0 \wedge \pm \varepsilon \cdot, r r$ & $\checkmark V$ & $r \ldots>-r \ldots$ & \\
\hline \multirow[t]{3}{*}{$1, r q-$} & 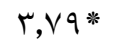 & & $1 \cdot, 17 \pm r q, 0 \leq$ & 0 . & . . . بفأكثر & \\
\hline & & & $\Upsilon, \wedge \Lambda \pm Y \Sigma, \cdot \vee$ & ov & $r \ldots\rangle$ & \multirow{3}{*}{ والمواصلات العمل } \\
\hline & $\curlyvee, \wedge \Lambda *$ & $0, Y \leq * *$ & $7, V \backslash \pm Y Y, 09$ & VV & $r \ldots>-r \ldots$ & \\
\hline \multirow[t]{3}{*}{$1, \leqslant 0-$} & $r, \varepsilon r$ & & $\vee, \cdot 1 \pm r \uparrow, 0$. & 0. & . . . . بأكثر & \\
\hline & & & $19, \cdot 1 \pm \wedge \wedge, \vee r$ & ov & $r \ldots>$ & \multirow{3}{*}{ إلتدابير اتباع } \\
\hline & 11,74 & $7, r_{0} * *$ & $\mid \wedge, \pi r \pm 1 \ldots, r \varepsilon$ & $\checkmark V$ & $r \ldots>-r \ldots$ & \\
\hline$r, T \leqslant-$ & $\wedge, 9 \wedge *$ & & । $, \vee \wedge \pm ৭ \vee, \vee$. & 0. & . . . . بأكثر & \\
\hline
\end{tabular}

الفرض العاشر: ينص هذا الفرض على أنه "لا يوجد تباين والوعي بالتدابير الوقائية الواجب اتباعها”، أشارت نتائج

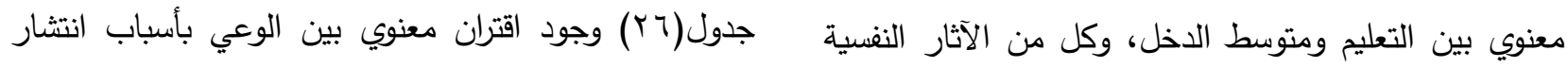
والاجتماعية الناتجة عن البقاء بالمنزل خلال فترة الحظر الإصابة بفيروس كورونا المستجد وكل من منطقة السكن

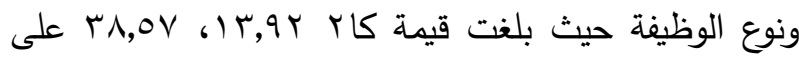
التوالي عند مستوى احتمالي ا +.,.، ا +.,., على التوالي، المنزلي والعوائق التي تواجه عينة الدراسة في اتباع التدابير الوقائية"، أوضحت نتائج جدول(Y0) عدم وجود تباين معنوي لوائ كما أوضحت النتائج عدم وجود اقتران معنوي بين الوعي بالتدابير الوقائية ككل وكل من منطقة السكن ونوع الوظيفة، في حين وجد اقتران معنوي بين كل من منطقة السكن ونوع

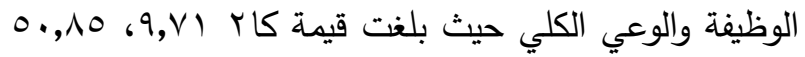
بين كل من التعليم ومتوسط الدخل، والآثار النفسية والاجتماعية الناتجة عن البقاء بالمنزل خلال فترة الحظر المنزلي والعوائق التي تواجه عينة الدراسة في اتباع التدابير الوقائية، وتُدعم هذه النتائج قبول الفرض العاشر كلياً. على التوالي عند مستوى احتمالي ه., •. 1. +.,. على التوالي، الفرض الحادي عشر: ينص هذا الفرض على أنه "لا يوجد اقتران معنوي بين منطقة السكن ونوع الوظيفة، وكل من الوعي بأسباب وأعراض مرض فيروس كورونا المستجد

جدول ه ب. قيمة "ف" لتحليل التباين ANOVA في اتجاه واحد للآثار النفسية والاجتماعية خلال فترة الحظر وعوائق اتباع التدابير وفقا لمستوى التعليم ومتوسط الاخل الثهري للأسرة

\begin{tabular}{ccr}
\hline متوسط الدخير التعليم المستقلة & & \\
\hline
\end{tabular}


جدول ج r ـ قيم مربع كاي بين الوعي بالتدابير الوقائية لأفراد العينة وكل من منطقة السكن ونوع الوظيفة

\begin{tabular}{|c|c|c|c|c|c|c|}
\hline \multicolumn{6}{|c|}{ الوعي } & \multirow[t]{3}{*}{ المتغيرات التابعة } \\
\hline \multirow[b]{2}{*}{ إجمالي الوعي } & & ابير الوقائية & الوعي با & & سباب وأعراض & \\
\hline & الوقيائية كبل ابير & والميئة العلاتل & التسوق الآمن & الثخصية النظافة & بالفيروس الابة & \\
\hline $9, \vee \vee *$ & $1,9 \varepsilon$ & $\varepsilon, r q$ & $\varepsilon, \vee \backslash$ & $r, 7 \Lambda$ & Tr,9r** & منطقة السكن \\
\hline $0 ., \wedge 0 * * *$ & $\Lambda, r$. & $7, .7$ & $1 \cdot, V \vee$ & $V, O Y$ & 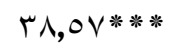 & نوع الوظيفة \\
\hline
\end{tabular}

كما اسفرت النتائج أن أكثر من ثلث عينة الدراسة ممن يقطنون الأحياء الراقية ويشغلون وظائف مهنية كان مستوى ممارساتهم في اتباع التدابير الوقائية ككل جيدة حيث بلغت وهاء

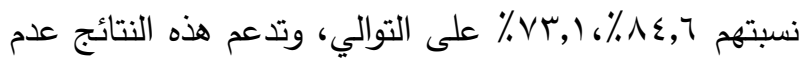
وعيهم مرتفع يقطنون مناطق سكنية راقية حيث بلغت نسبتهم قبول الفرض الثاني عشر كلياً.

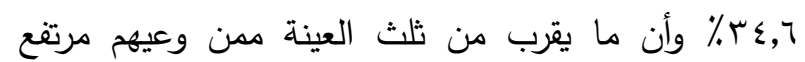
يعملوا بأعمال مهنية حيث بلغت نسبتهم ^, بץ\%، وتُدعم هذه الفرض الثالث عشر: ينص هذا الفرض على أنه "لا يوجد النتائج عدم صحة الفرض الحادي عشر جزئياً. اقتران معنوي بين منطقة السكن ونوع الوظيفة، وكل من الفرض الثاني عشر: ينص هذا الفرض على أنه "لا يوجد الآثار النفسية والاجتماعية الناتجة عن البقاء بالمنزل خلال اقتران معنوي بين كل من منطقة السكن ونوع الوظيفة، واتباع فترة الحظر المنزلي والعوائق التي تواجه عينة الدراسة في

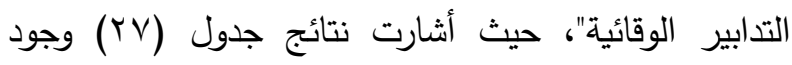
اتباع التدابير الوقائية". أوضحت النتائج البحثية جدول (r^) عدم وجود اقتران معنوي بين كل من منطقة السكن ونوع الوظيفة، اقتران معنوي بين اتباع التدابير الوقائية وكل من منطقة

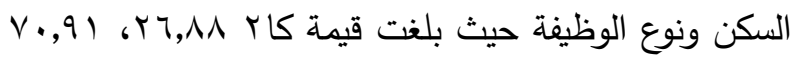
على التوالي عند مستوى احتمالي ا +.,..، كما اسفرت النتائج البحثية أن الغالبية العظمى من أفراد العينة ممن

جدول V . . قيم مربع كاي بين اتباع التدابير الوقائية لأفراد العينة وكل من منطقة السكن ونوع الوظيفة

\begin{tabular}{|c|c|c|c|c|}
\hline \multicolumn{4}{|c|}{ اتباع التدابير الوقائية } & \multirow[t]{2}{*}{ المتغيرات التابعة } \\
\hline التباع التّابير ككل & اتباع تدابير بيئة العمل & ألآمن والتتجمعات التسوق & اتباع تدابير النظافة & \\
\hline 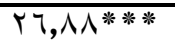 & $1 \Gamma, 00 * *$ & $9, .7 * * *$ & Y, $90 * * *$ & منطقة السكن \\
\hline$V \cdot, q 1 * * *$ & r & $7 ., 70 * * *$ & V0,77*** & نوع الوظيفة \\
\hline
\end{tabular}

جدول ^ץ. قيم مربع كاي بين للآثار النفسية والاجتماعية خـلال فترة الحظر وعوائق اتباع التدابير وكل من منطقة السكن ونوع الوظيفة

\begin{tabular}{|c|c|c|}
\hline \multicolumn{2}{|c|}{ الآثار النفسية والاجتماعية خلال فترة الحظر وعوائق اتباع التدابير } & \multirow[t]{2}{*}{ المتغيرات التابعة } \\
\hline عوائق اتباع التدابير & آثار الحظر المنزلي & \\
\hline T,,$Y$ & $\varepsilon, \Gamma$ & منطقة السكن \\
\hline 1,0 . & $r, ., 1$ & 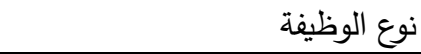 \\
\hline
\end{tabular}


سادساً: الدراسة التجريبية: 1- الثاملة والعينة التجريبية:

الثاملة: العاملين بكلية الزراعة- جامعة الاسكندرية.

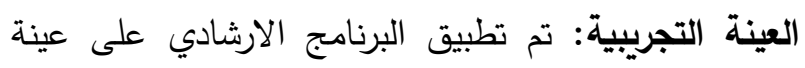

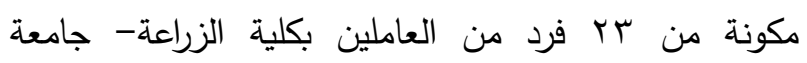
الاسكندرية، ولديهم الرغبة في الاشتراك بالبرنامج.

الهذف من البرنامج الارشادي:

تتمية وعي وتعزيز سلوك المسترشدين بالتدابير الوقائية

اللازمة للحد من انتثار فيروس كورونا المستجد.

r- بناء وتنفيذ البرنامج الارشادي:

تم قياس وعي العينة التجريبية بالتدابير الوقائية للوقاية والدد من انتثار فيروس كورونا المستجد ومدى التزامهم باتباع هذه

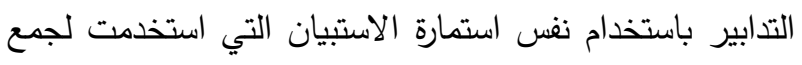

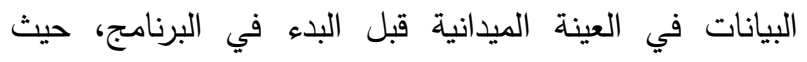

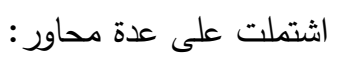
المحور الأول: الوعي بأسباب انتشار وأعراض الإصابة

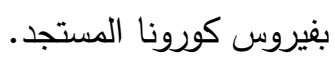
المحور الثاني: الوعي بالتدابير الوقائية الخاصة بـ:

أ- النظافة الثخصية

ب- التباعد الاجتماعي عند التسوق والتجمعات.

$$
\text { ج- بيئة العمل والمواصلات العامة. }
$$

المحور الثالث: مدى اتباع التدابير الوقائية للوقاية من

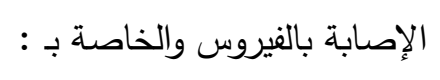

أ- النظافة الثخصية

ب- التباعد الاجتماعي عند التسوق والتجمعات. ج- بيئة العمل والمواصلات العامة.
والآثار النفسية والاجتماعية الناتجة عن البقاء بالمنزل خلال

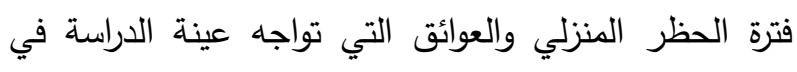

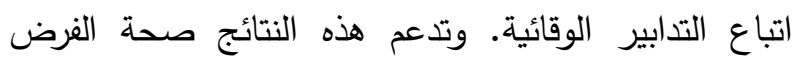

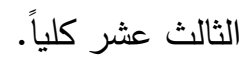

بناء وتنفيذ برنامج ارشادي لتنمية الوعي وتعزيز السلوك بالتدابير الوقائية للحد من انتثار فيروس كورونا. تم دراسة الوضع الحالي لوعي وممارسات افراد العينة بمدى التزامهم باتباع التدابير الوقائية للوقاية والدد من الإصابة

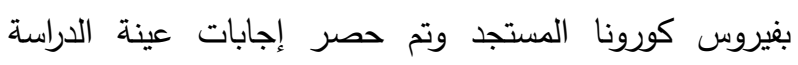
(£) (مبحوث ومبحوثة) من حيث الوعي والممارسات الوقائية

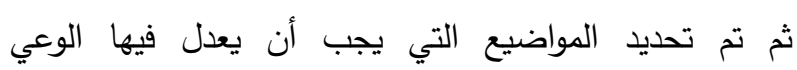

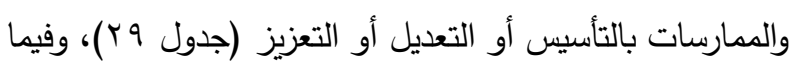

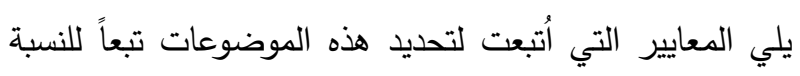

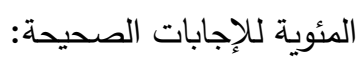

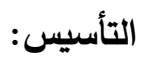
- الـوعي بأسـباب وأعـراض الإصــابة بـالفيروس والــوعي

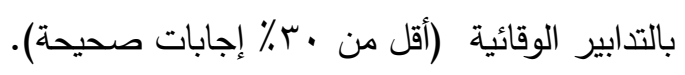

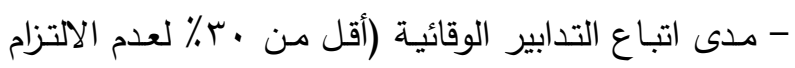
باتباع التدابير ).

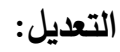

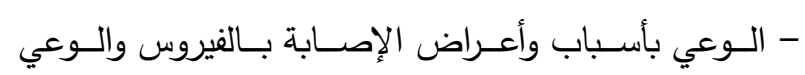

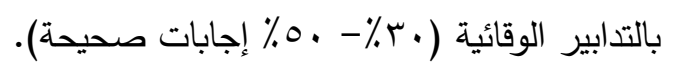

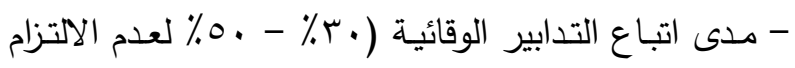
باتباع التدابير ).

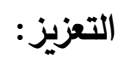

- الـوعي بأسـباب وأعـراض الإصـابة بـالفيروس والـوعي بالتدابير الوقائية (أكثر من .0 \% إجابات صحيحة).

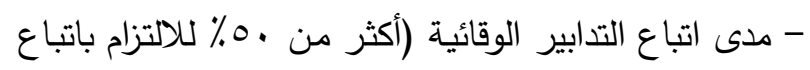
التدابير). 


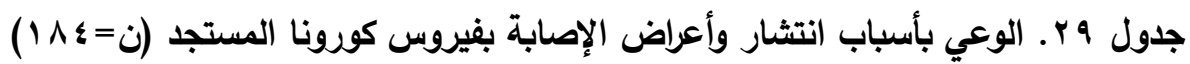

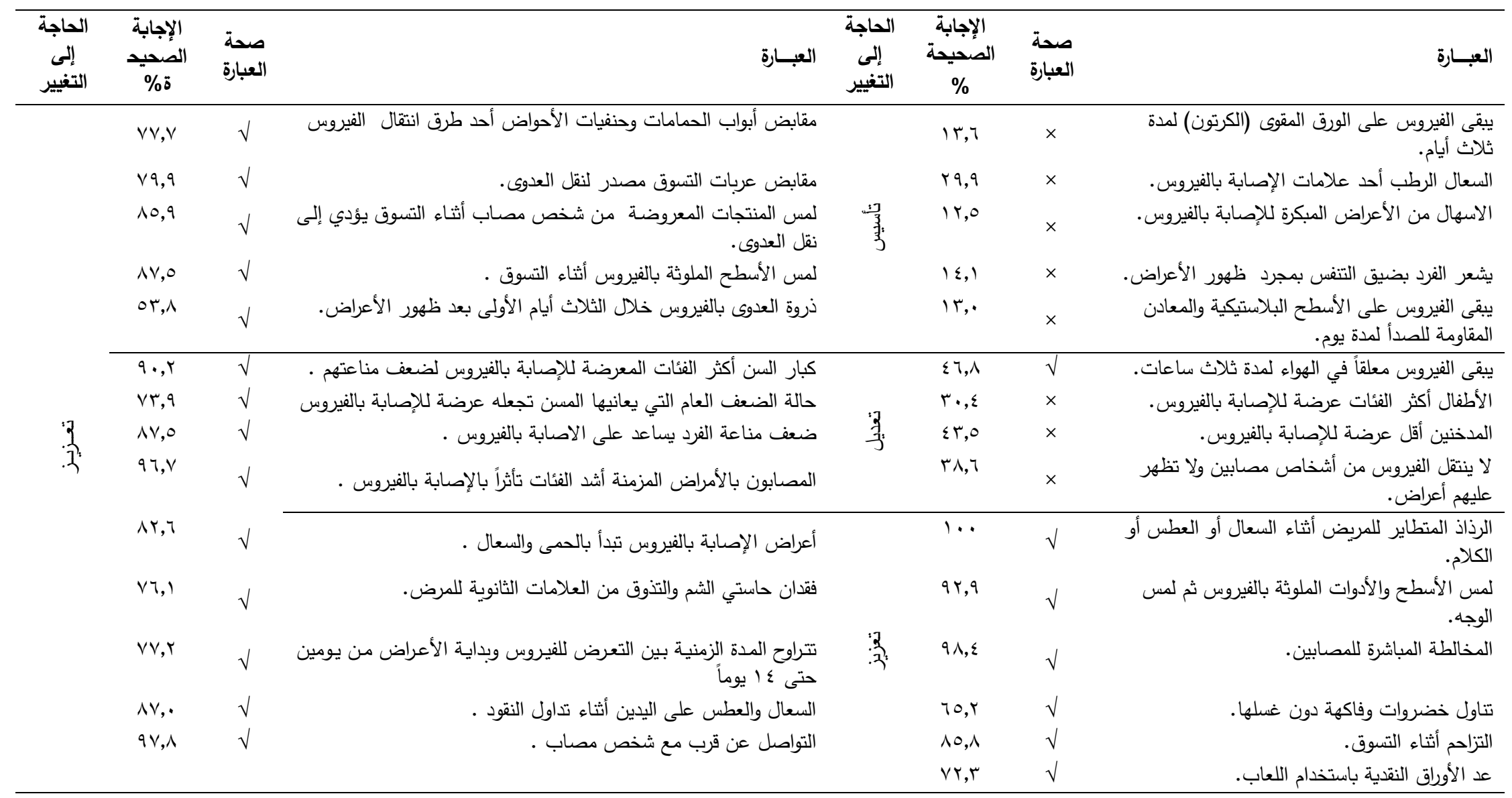


346 مجلة الإسكندرية للتبادل العلمى - (مجلد إع العدد I) يناير - مارس اY.r

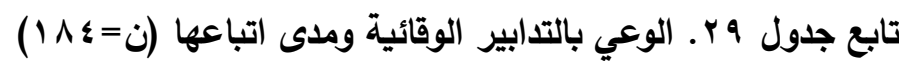

\begin{tabular}{|c|c|c|c|c|c|c|c|c|c|}
\hline \multicolumn{2}{|c|}{ الحاجة إلى التغيير } & \multicolumn{2}{|c|}{ الإجابة الصحيحة\%\% } & \multirow{2}{*}{ 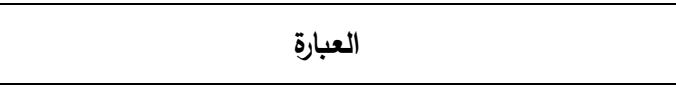 } & \multicolumn{2}{|c|}{ الحاجة إلى التغيير } & \multicolumn{2}{|c|}{ الإجابة الصحيحة\%\% } & \multirow{2}{*}{ 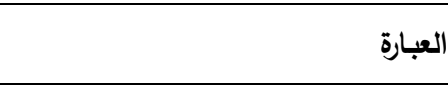 } \\
\hline ممارسة & وعى & ممارسة & وعى & & ممارسة & وعى & ممارسة & وعى & \\
\hline \multirow{2}{*}{ ت تعديل } & \multirow{8}{*}{3} & M 1,7 & $\wedge \cdot, \varepsilon$ & وصأبون الجزء الخارجي للبضائع المعلبة عند شرائها بماء & \multirow{3}{*}{ 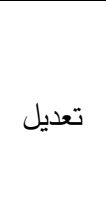 } & \multirow{11}{*}{$\frac{3}{3}$} & & & النظافة الشخصية \\
\hline & & $\varepsilon \vee, r$ & $9 \leq, 7$ & المحافظة على مسافة كافية بين الأفراد (التباعد الجسدي) & & & $\varepsilon \varepsilon, 7$ & $\wedge 9,1$ & 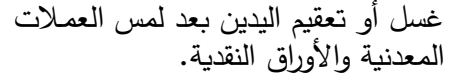 \\
\hline \multirow{6}{*}{3} & & $V Y, r$ & 94,0 & العزل المنزلي إذا تواجد الفرد مع شخص مصاب. & & & $07, \cdot$ & $91, r$ & 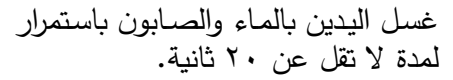 \\
\hline & & $\wedge r, l$ & $\wedge ৭, 乏$ & تجنب الاقتراب من أي شخص لديه أعراض المرض. & & & 90,1 & 99,0 & غسل اليدين بعد الذهاب للمرحاض. \\
\hline & & $7 \cdot, 9$ & 90,7 & تجنب المصافحة والاكتّفاء بالترحيب بالتلويح أو الايماءات . & & & $\wedge \wedge, \cdot$ & 99,0 & غسل اليدين قبل و \\
\hline & & $7 \cdot$, & $9 \vee, \wedge$ & ارتداء أقنعة الوجه الطبية (الكمامات) في الأماكن العامة & & & $V \leqslant, 0$ & $99, \cdot$ & 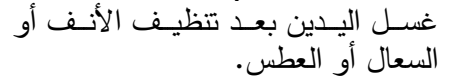 \\
\hline & & $0 \leqslant, 9$ & $9 \cdot, \wedge$ & الالتزام بالوقوف على العلامات المحددة من قِبل المحلات & & & $\wedge 1,0$ & $9 \wedge, \Sigma$ & غســل اليـدين بالمـاء والصـابون بمجـرد \\
\hline & & $\wedge \bullet, \wedge$ & $\wedge \wedge, \uparrow$ & 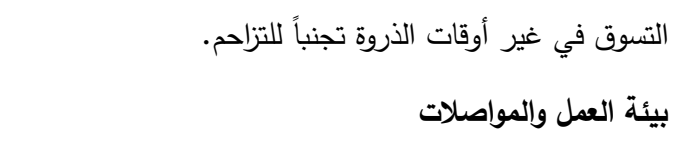 & ?.? & & $\begin{array}{l}0 \leqslant, 9 \\
00, \varepsilon\end{array}$ & $\begin{array}{l}\wedge 9,7 \\
94,0\end{array}$ & 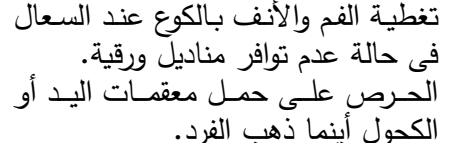 \\
\hline \multirow{3}{*}{ 然 } & \multirow{12}{*}{3} & $r_{0,0}$ & $\wedge \vee, 0$ & تطهير مقابض الأبواب بأماكن العمل. & & & or, & $97, r$ & تأجنـب غلامسيرة العين أو الأنف أو الفم \\
\hline & & $r 7,1$ & $\vee ৭, 乏$ & غالايدي الحنفيات وفتح الأبواب باستخدام مناديل ورقية بعد غسل & & & $7 V, 9$ & $9 \vee, r$ & 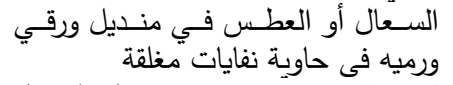 \\
\hline & & $r v, \Lambda$ & $\Lambda \cdot, \Sigma$ & منها ـ. استخدم المناديل الورقية عند لمس أزرار المصاعد والتخلص & & & $0 \leqslant, \Gamma$ & $\lambda r, l$ & 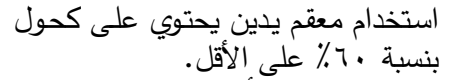 \\
\hline \multirow{5}{*}{ '3 } & & $\leqslant 1, \wedge$ & $97, \vee$ & تتكرزف سطح المكتب لأنها من الأسطح التي تلمس بشكل & & \multirow{9}{*}{3} & $\vee \vee, \vee$ & $\wedge \varepsilon, \wedge$ & 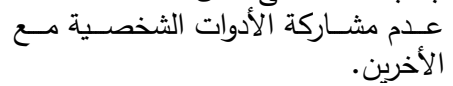 \\
\hline & & $\varepsilon r, 0$ & 90,1 & 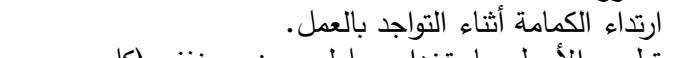 & & & & & التباعد الاجتماعى والتسوق \\
\hline & & r T, & $9 \cdot, r$ & مخفف). الاسطح باستخدام محلول مبيض مخفف (كلور & ت تأسيس & & $Y \uparrow, V$ & $\wedge, \cdot$ & 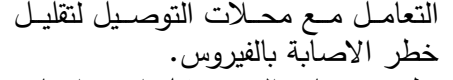 \\
\hline & & $\varepsilon \cdot, r$ & $\wedge \varepsilon, r$ & تجنب لُمس الأسطح أثناء ركوب المواصلات. & \multirow{6}{*}{ '? } & & $r \leqslant, r$ & $\wedge ৭, \vee$ & تطهير عربات التسوق قبل استخدامها. \\
\hline & & $\varepsilon \leqslant, 7$ & $9 r, 0$ & تجنب ركوب المواصدلات المزدحمة حفاظاً على التباعد & & & $\Gamma \cdot, \Sigma$ & $\wedge r, \uparrow$ & خلالب التسوق. لمس الكثيـر مـن المعروضـات \\
\hline \multirow{4}{*}{3} & & $7 r, 1$ & $9 \wedge, \varepsilon$ & تالفوية المكاتب عن طريق فتح النوافذ للحماية من الاصابة & & & r & $9 \leq, 1$ & تلعقـيم اليــد مباشـرة بعـد الانتهـاء مـن \\
\hline & & $V T, \varepsilon$ & $9 \wedge, 9$ & فتح النوافذ كلما أمكن ذلك أثناء ركوب المواصـلات. & & & $r \mu, r$ & $\wedge \wedge, \cdot$ & التسوق قبل الاستخدام الامـاكن التي تعقم عربـات \\
\hline & & $V T, 9$ & $10, r$ & تجنب تتاول أي أطعمة أثناء ركوب المواصلات. & & & $\varepsilon 0, V$ & $9 r, 0$ & تجنب لمس الوجه أثناء التسوق. \\
\hline & & $7 r, \cdot$ & $97, \vee$ & ارتداء الكمامة عند ركوب المواصلات. & & & ґ৯,. & 91,9 & تعقيم اليد فور مغادرة المحل. \\
\hline
\end{tabular}


البرنامـج الارشادي:

برنامج ارشادي لتنمية الوعي وتعزيز سلوك المسترشدين بالتدابير الوقائية اللازمة للحد من انتشار فيروس كورونا المستجد

\begin{tabular}{|c|c|c|c|c|}
\hline طرق التقييم & الطرق والوسبائل & عناصر الدرس & الأهداف التعليمية & الوحدة التعليمية \\
\hline الدرجيـه وتطئلة في محتويـات. & 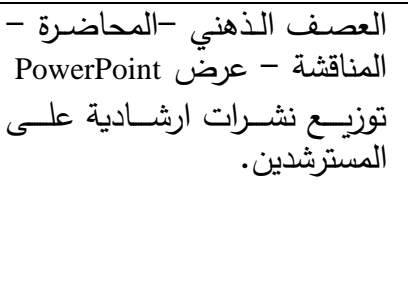 & 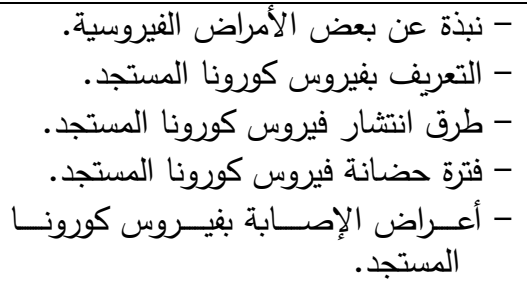 & 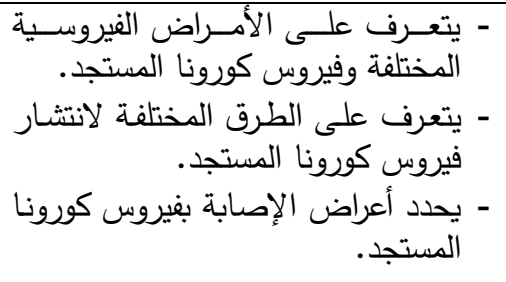 & 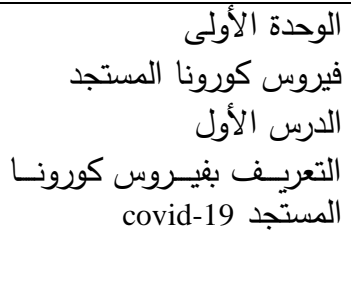 \\
\hline 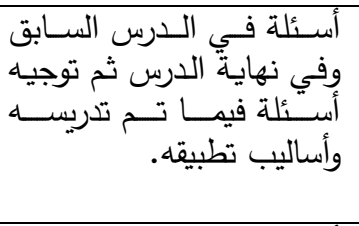 & 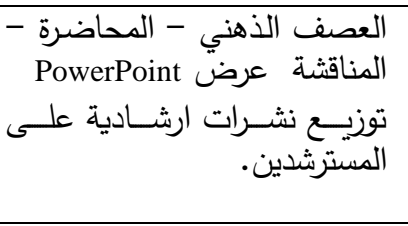 & 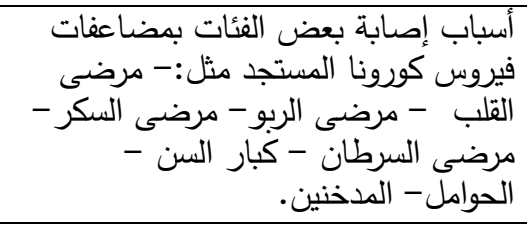 & 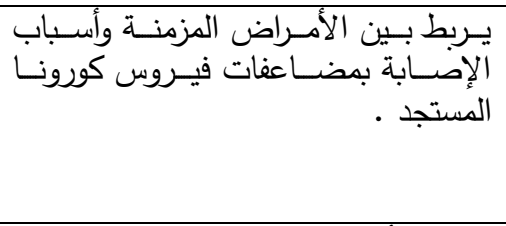 & 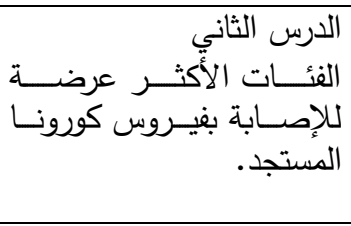 \\
\hline 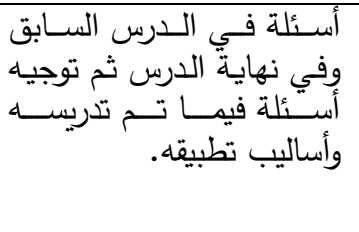 & 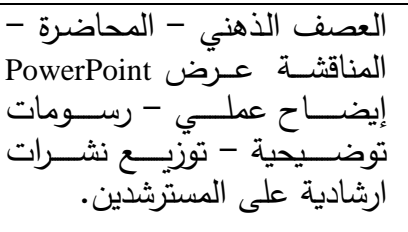 & - النظافة الثخصية. & 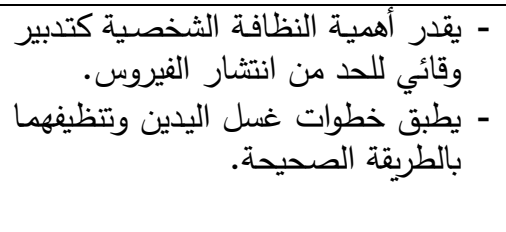 & 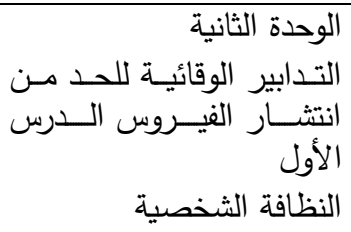 \\
\hline طرق التقييم & الطرق والوسائل & عناصر الدرس & الأهداف التعليمية & الوحدة التعليمية \\
\hline 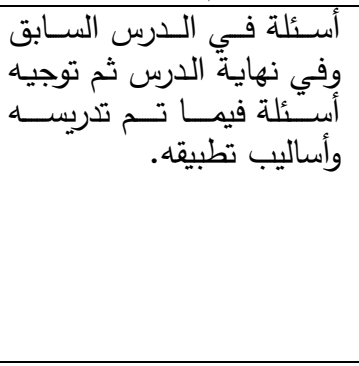 & 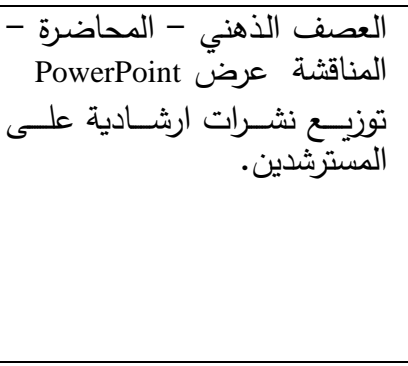 & 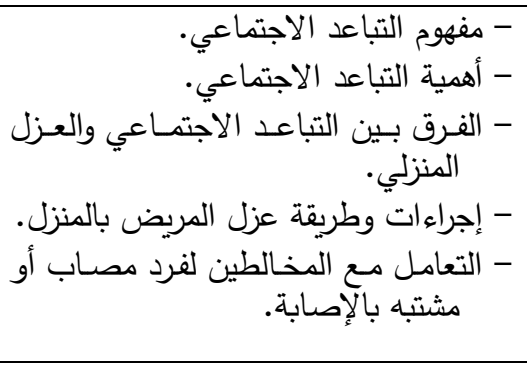 & 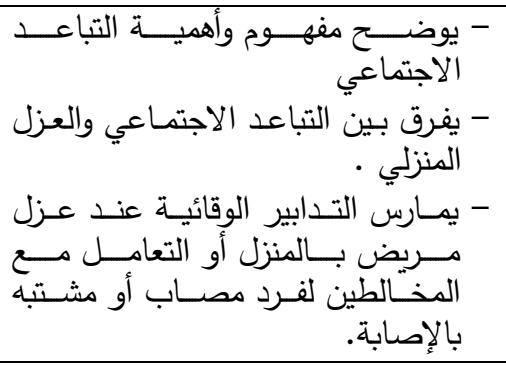 & التباعد الاجتم الثاني \\
\hline
\end{tabular}


تابع: برنامج ارشادي لتنمية الوعي وتعزيز سلوك المسترشدين بالتدابير الوقائية اللازمة للحد من انتثار فيروس كورونا المستجد

\begin{tabular}{|c|c|c|c|c|}
\hline طرق التقييم & الطرق وإلوسائل & عناصر الارب & الأهداف التعليمية & الوحدة التعليمية \\
\hline 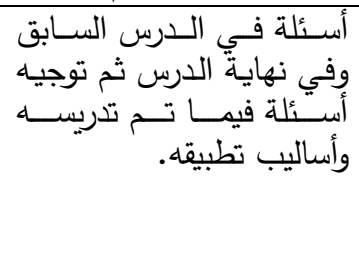 & 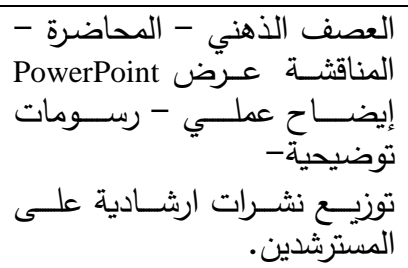 & - أهطوات ارتداء الكمامة. & 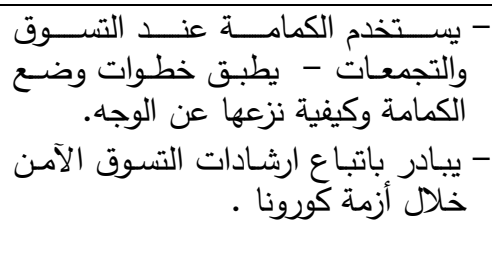 & 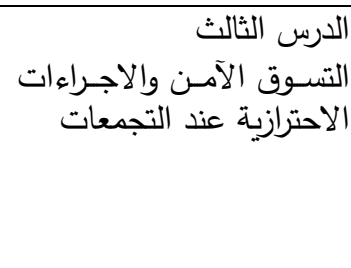 \\
\hline 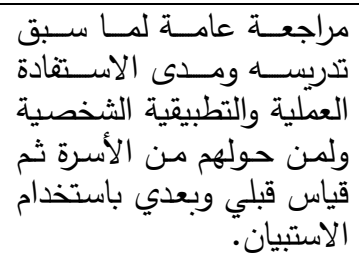 & 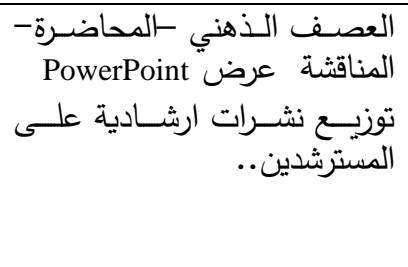 & 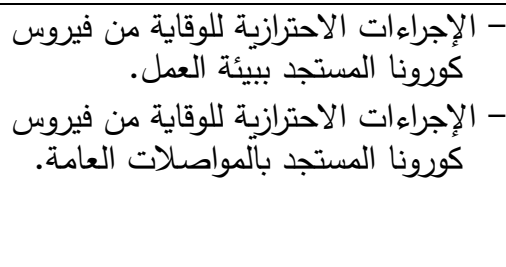 & 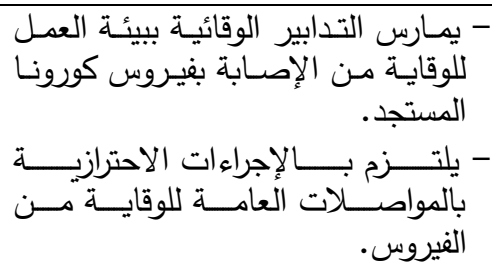 & البئُسـة العمـل والمواصــلات \\
\hline
\end{tabular}

جدول · س. درجات الوعي والوعي بالالتزام باتباع التدابير الوقائية للوقاية من فيروس كورونا المستجد قبل وبعد تنفيذ البرنامج

\begin{tabular}{|c|c|c|c|c|c|c|c|c|c|c|c|c|c|c|c|c|c|c|c|c|}
\hline \multicolumn{8}{|c|}{ الوعي بالالتزام باتباع التدابير الوقائية } & \multicolumn{12}{|c|}{ الوعي بالتدابير الوقائية } & \multirow{3}{*}{ الارجات والمدى } \\
\hline \multicolumn{2}{|c|}{ إجمالَي الوعزام } & \multicolumn{2}{|c|}{ والثمواصلات العمل } & \multicolumn{2}{|c|}{ والتسوق الآمن } & \multicolumn{2}{|c|}{ الثخصية } & \multicolumn{2}{|c|}{ إجمالي الوعي } & \multicolumn{2}{|c|}{ بالتالتابيير } & \multicolumn{2}{|c|}{ والمواصلات العمل } & \multicolumn{2}{|c|}{ والتسوق الآمن } & \multicolumn{2}{|c|}{ الثخصية } & \multicolumn{2}{|c|}{ أسأعراض ألفباب } & \\
\hline بعد & قبل & بعد & قبل & بعد & ق قبل & بعد & قبل & بعد & قبل & بعد & قبل & بعد & قبل & بعد & قبل & بعد & قبل & بعد & قبل & \\
\hline IrT & $11 \mathrm{~V}$ & $\begin{array}{l}5 \\
1\end{array}$ & rq & 01 & 01 & r4 & rq & $r \cdot \varepsilon$ & 199 & ITr & KT & r4 & Mi & 01 & 01 & r4 & rq & 1) & $v_{4}$ & أكبر درجة مشاهدة \\
\hline $1 . r$ & $\varepsilon 1$ & $\begin{array}{l}r \\
\Lambda\end{array}$ & Ir & $\varepsilon \varepsilon$ & IV & rA & Ir & $1 \mathrm{VI}$ & $1 . V$ & $1 . r$ & $\leqslant 9$ & rA & IT & $\varepsilon \varepsilon$ & 19 & r^ & 10 & TV & or & أصغر درجة مشاهدة \\
\hline$r \cdot$ & $v_{4}$ & $\wedge$ & $r \leq$ & v & $r \varepsilon$ & $\wedge$ & $r \varepsilon$ & r & 94 & $r \cdot$ & $v \varepsilon$ & $\wedge$ & $r \varepsilon$ & v & rt & $\wedge$ & r) & $1 \varepsilon$ & $r \varepsilon$ & 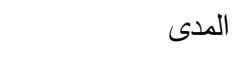 \\
\hline v & ro & $r$ & $\wedge$ & r & 11 & r & $\wedge$ & 11 & r & v & ro & $r$ & $\wedge$ & r & 11 & $r$ & V & 0 & $\wedge$ & طول الفئة \\
\hline
\end{tabular}


جدول آ. مستويات الوعي بالتدابير الوقائية للوقاية من فيروس كورونا المستجد قبل وبعد تنفيذ البرنامج

\begin{tabular}{|c|c|c|c|c|c|c|c|c|c|c|c|c|}
\hline \multicolumn{12}{|c|}{ الوعي بالتدابير الوقائية } & \multirow{3}{*}{ المستويات } \\
\hline \multicolumn{2}{|c|}{ إجمالي الوعي } & \multicolumn{2}{|c|}{ الوعي بالتدابير الوقائية ككل } & \multicolumn{2}{|c|}{ بيئة العمل والمواصلات } & \multicolumn{2}{|c|}{ التسوق الآمن والتجمعات } & \multicolumn{2}{|c|}{ النظافة الثخصية } & \multicolumn{2}{|c|}{ ألاصنبابة بأعزاضيروس } & \\
\hline بعد & قبل & بعد & قبل & بعا & قبل & بعد & قبل & بعد & قبل & بعد & قبل & \\
\hline$|A r>-| V \mid$ & $\mid r \wedge>-1 \cdot v$ & $11 .>-1 . r$ & $V \varepsilon>-\varepsilon 9$ & $r>-Y \Lambda$ & $r \cdot>-1 r$ & \{\rceil$>-\varepsilon \varepsilon$ & $r \cdot>-19$ & $\lceil\mid>-\Upsilon \Lambda$ & $r Y>-10$ & $V T>-4 V$ & $r \cdot>-O r$ & المنخفض الوعي \\
\hline $19 T>-1 A T$ & $179>-14 \lambda$ & $11 y>-11$. & $99>-V \varepsilon$ & $r \leqslant>-r \mid$ & $r \wedge>-r$. & $\{\wedge>-\varepsilon \uparrow$ & $\varepsilon 1>-r$. & $r \varepsilon>-r \mid$ & $r q>-r r$ & $V Y>-V Y$ & $\eta \wedge>-\eta$ & الفئَّوسطي \\
\hline بهو ا فأكثر & (79 179 & 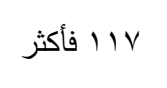 & 99 فأكثر & 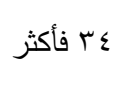 & 1 Y ب أكثر & يـ فأكثر & 1 إ فأكثر & ع ع فأكثر & ج ج فأكثر & فأكثر VV & ^ף فأكثر & المرزئة الوعي \\
\hline
\end{tabular}

جدول r r. مستويات الوعي بالالتزام باتباع التدابير الوقائية للوقاية من فيروس كورونا المستجد قبل وبعد تنفيذ البرنامج

\begin{tabular}{|c|c|c|c|c|c|c|c|c|}
\hline \multicolumn{8}{|c|}{ الوعي بالتزام اتباع التدابير الوقائية } & \multirow{3}{*}{ 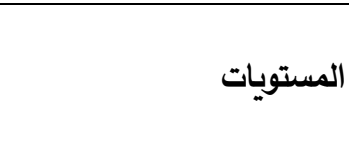 } \\
\hline \multicolumn{2}{|c|}{ اجمالي الوعي بالالتزام } & \multicolumn{2}{|c|}{ بيئة العمل والمواصلات } & \multicolumn{2}{|c|}{ التسوق الآمن والتجمعات } & \multicolumn{2}{|c|}{ النظافة الثخصية } & \\
\hline بعد & قبل & بعد & قبل & بعد & قبل & بعد & قبل & \\
\hline $11 \cdot>-1 \cdot r$ & $77>-\xi 1$ & $r \mid>-Y \Lambda$ & $T \cdot>-1 Y$ & \{\rceil$>-\varepsilon \xi$ & $Y \wedge>-I V$ & $r \mid>-Y \Lambda$ & $r \cdot>-I Y$ & فئة الوعي بالالتزام المنخفض \\
\hline 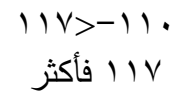 & $\begin{array}{l}91>-47 \\
91 \text { فأكثر } 91\end{array}$ & 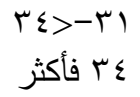 & 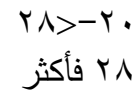 & 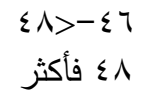 & 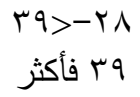 & 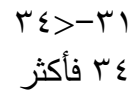 & $\begin{array}{l}r \wedge>-r . \\
\text { A } 1 \text { فأكثر }\end{array}$ & فئة الوعي بالوعي بالالتزام المتوسط المرتعع \\
\hline
\end{tabular}


Zhong ,et al (2020) أدت إلى تحسن وعي وممارسات الأفراد تجاه الالتزام باتخاذ التدابير الوقائية للوقاية والحد من انتشار فيروس كورونا المستجد.

الفرض الرابع عشر: ينص هذا الفرض على أنه " لا يوجد فرق معنوي لكل من الوعي بالتدابير الوقائية والالتزام بأتباعها لدى عينة الدراسة قبل وبعد تتفيذ البرنامج". اتضتح من نتائج جدول (0) وجود فروق دالة إحصائياً بين الوعي بالتدابير الوقائية والوعي بالالتزام نحو اتباع هذه

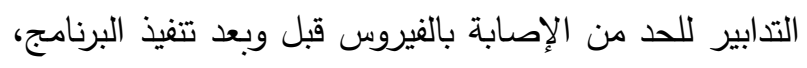
حيث كان المتوسط الحسابي والانحراف المعياري قبل تتفيذ البرنامج فيما يتعق بالوعي بالتدابير الوقائية ككل والوعي

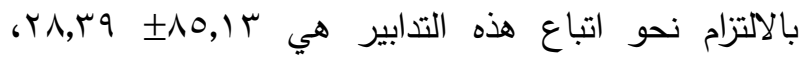

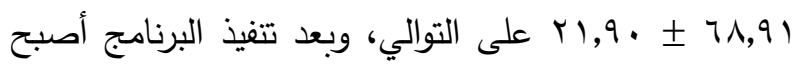

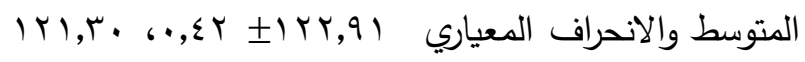

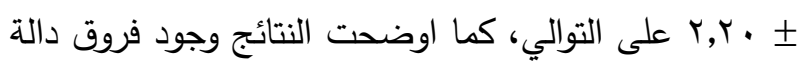

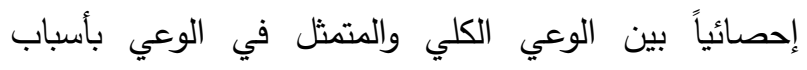
وأعراض الإصسابة بالفيروس والوعي بالتدابير الوقائية ككل قبل وبعد تتفيذ البرنامج حيث كان المتوسط الحسابي

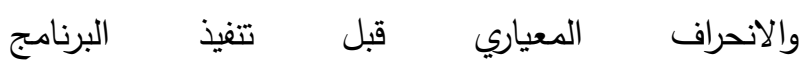
• .

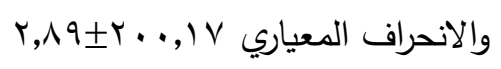

مما سبق يتضح من النتائج أن قيمة "ت" قبل و بعد تتفيذ

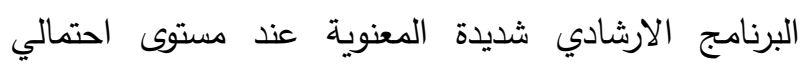
1.....، أي أن البرنامج ساهم بدلالة إحصائية في رفع الوعي بالتدابير الوقائية والوعي الكلي والوعي بالالتزام باتباع

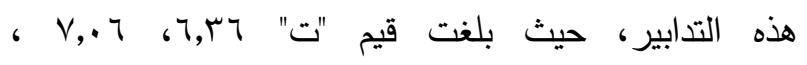
جr, 1 ا (على التوالي.
ب- قياس فاعلية البرنامج الارشادي: تم تحويل البيانات الوصفية إلى كمية وحساب مستويات الوعي والوعي بضـرورة الالتزام باتباع التدابير الوقائية قبل وبعد تتفيذ البرنامج الارشادي. النتائج البحثية للعينة التجريبية: يتضح من جدول (سr) أن و, و \% من عينة البحث

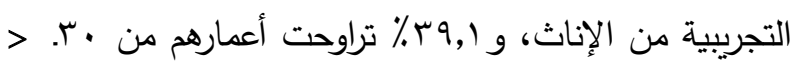

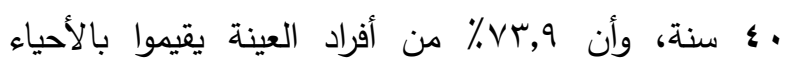
الشعبية، وأن الغالبية العظمى متزوجون ولديهم أبناء حيث

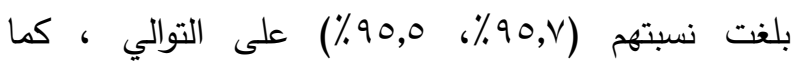
أوضحت النتائج البحثية أن ب,9 \% أميين، وبالسؤال عن

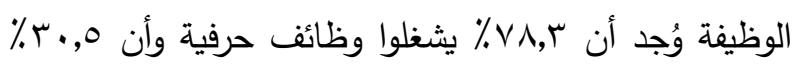

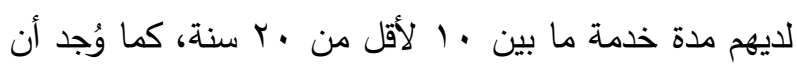

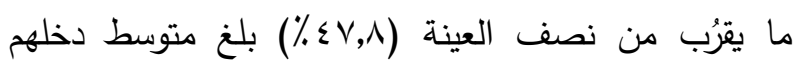

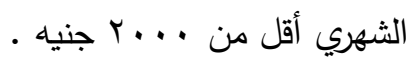
يوضح جدول (ع ب) توزيع أفراد العينة التجريبية تبعاً لمستوى وعيهم بالتدابير الوقائية ومستوى وعيهم بالالتزام باتباع

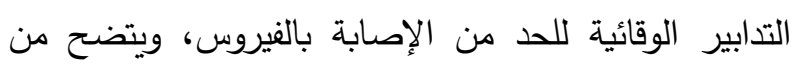
النتائج أن مستوى الوعي الجيد بالتدابير الوقائية ككل ارتفع

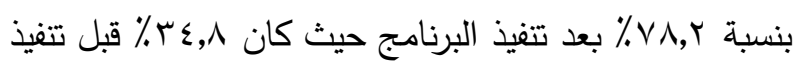
البرنامج، كما أوضحت النتائج أن الغالبية العظمى من أفراد

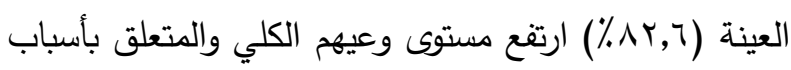

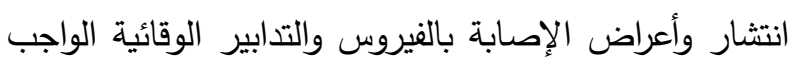
اتباعها والمتعلقة بالنظافة الثخصية وعند التسوق والتجمعات

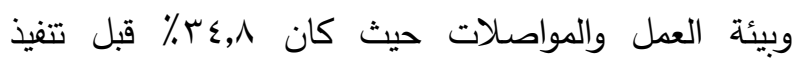
البرنامج ، وفيما يتعلق بالتزام أفراد العينة باتباع التدابير الوقائية قبل وبعد تتفيذ البرنامج، أوضحت النتائج البحثية بنفس الجدول ارتفاع معدل الوعي الجيد بالالتزام بعد تتفيذ

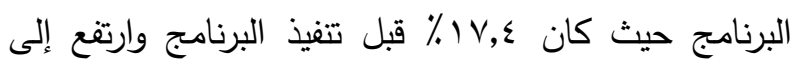
\% \% ب,Y بعد التنفيذ، وتتفق هذه النتائج مع نتائج دراسة 
جدول بr. توزيع افراد العينة التجريبية تبعاً للخصائص الاجتماعية- الاقتصادية (ن = ب r )

\begin{tabular}{|c|c|c|c|c|c|}
\hline$\%$ & عدد & الخصائص & $\%$ & عدد & الخصائص \\
\hline & & نوع الوظيفة & & & الجنس \\
\hline- & - & مهني & Yฯ, & 7 & ذكور \\
\hline rI, & 0 & إداري & $\vee r, q$ & iv & إناث \\
\hline$\vee \wedge, r$ & 11 & حرفي & $1 \ldots$ & rt & المجموع \\
\hline \multirow[t]{2}{*}{$1 \ldots$} & rtr & المجموع & & & \\
\hline & & عدد سنوات العمل & & & العمر بالسنوات \\
\hline YI,V & 0 & $1 \cdot>$ & $\varepsilon, \varepsilon$ & 1 & $r \cdot>$ \\
\hline$r \cdot, 0$ & $\checkmark$ & $r \cdot>-1$. & ५, , & 9 & $\varepsilon \cdot>-\mu$. \\
\hline 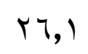 & 7 & $r \cdot>-r \cdot$ & $r \cdot, \varepsilon$ & $\checkmark$ & $0 .>-\varepsilon$. \\
\hline YI,V & 0 & • فأكثر & Yฯ, & 7 & $7 \cdot>-0$. \\
\hline \multirow[t]{2}{*}{$1 \ldots$} & rt & المجموع & $1 \ldots$ & rt & المجموع \\
\hline & & متوسط الدخل الشهري & & & منطقة السكن \\
\hline$\varepsilon \vee, \wedge$ & 11 & $r \ldots>$ & $\vee r, q$ & iv & شعبي \\
\hline$\varepsilon r, 0$ & 1. & $r \ldots>-r_{\ldots}$. & Yฯ,l & 7 & متوسط" \\
\hline$\Lambda, \vee$ & r & . . . . فأكثر & - & - & راقي \\
\hline \multirow[t]{2}{*}{$1 \ldots$} & rt & المجموع & $1 \ldots$ & rt & المجّموع \\
\hline & & الحالة الاجتماعية & & & المستوى التعليمي \\
\hline$\varepsilon, r$ & 1 & غير متزوج & $r q, r$ & 9 & \\
\hline $90, V$ & rr & متزوج & ir,. & r & يقراً ويكتب \\
\hline \multirow[t]{3}{*}{$1 \ldots$} & rt & المجموع & rฯ, & 7 & ابتدائية \\
\hline & & & $\Lambda, \vee$ & r & اعدادية \\
\hline & & وجود أبناء بالأسرة (ن= Yr) & $1 \pi$, & r & ثانوية أو ما يعادلها \\
\hline 90,0 & $r_{1}$ & يوجد & - & - & شهادة جامعية \\
\hline$\varepsilon, 0$ & 1 & ل لا يوجد & $1 \ldots$ & rt & المجموع \\
\hline $1 \ldots$ & rt & المجموع & & & \\
\hline
\end{tabular}


جدول ء ب. توزيع أفراد العينة التجرببية تبعاً لمستوى الوعي و الوعي بالالتزام باتباع التدابير الوقائية قبل وبعد تطبيق البرنامج الارشادي (ن=rr) الفئات

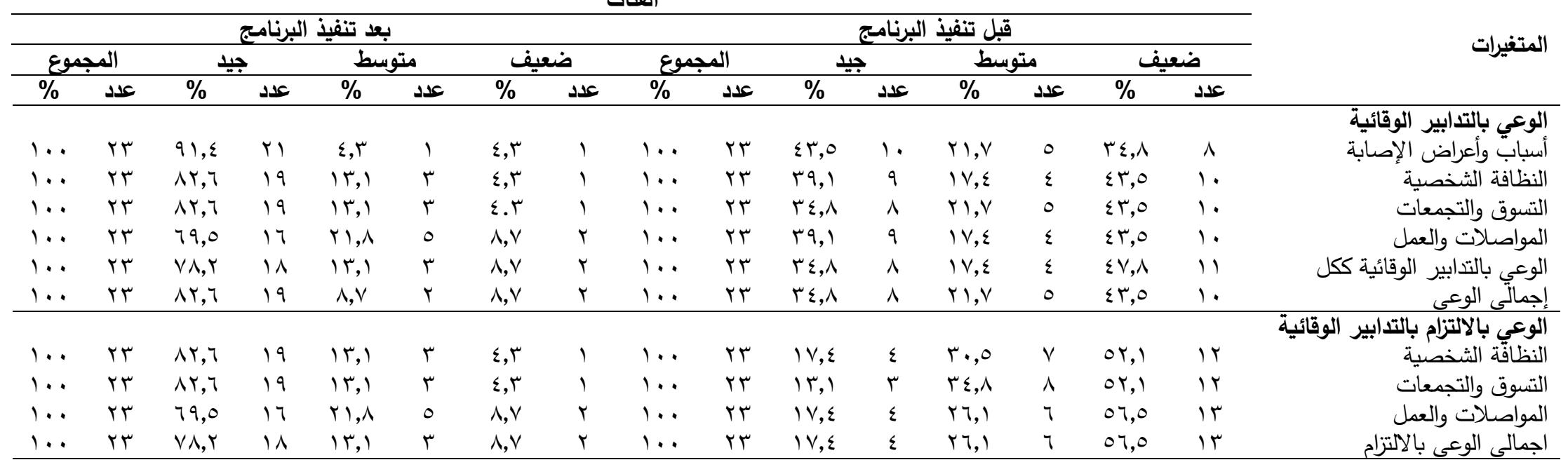

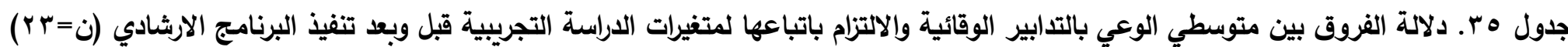

\begin{tabular}{|c|c|c|c|}
\hline قيمة "ت" & بعد تنفيذ البرنامج & قبل تنفيذ البرنامـج & المتغيرات \\
\hline $9, .0 * * *$ & $Y, \wedge \circ \pm V \vee, Y \Psi$ & $\Lambda, \cdot r \pm T \varepsilon, O V$ & أسبابِ وأعراض الوبير الإصائية \\
\hline $0, \vee \leqslant * * *$ & $\cdot, \cdots \pm r, \ldots$ & $\Lambda, \varepsilon r \pm r 0, q) \vee$ & النظافة الثخصية ' \\
\hline $7,1 \wedge * * *$ & $\cdot, \leqslant Y \pm 0 ., 91$ & $\mid r, 1 \cdot \pm r 0,1 v$ & التسوق والتجمعات \\
\hline 0,9 r*** & $\cdot, \cdot \pm m 4, \cdots$ & $9,79 \pm r \varepsilon, \cdot \varepsilon$ & المواصلات والعمل \\
\hline$\urcorner, \Upsilon\urcorner * * *$ & $\cdot, \varepsilon r \pm \mid r r, q 1$ & $r \wedge, r q \pm \wedge 0,1 r$ & الوعي بالتدابير الوقائية ككل \\
\hline$\vee, .7 * * *$ & $r, \wedge q \pm r \ldots, 1 \vee$ & $r 0,77 \pm 1 \leq 9, \vee$. & كي الوعى \\
\hline & & & الوعي بالالتزام بالتدابير الوقائية \\
\hline $1,1,1 * * *$ & $\cdot, \Lambda \leq \pm r_{0, O V}$ & $7,91 \pm r \mid, r$. & النظافَّة الشخصية \\
\hline $1 \cdot, \vee \vee \leqslant * * *$ & $1,0 Y \pm 0, r 0$ & $q, O V \pm Y V, V \wedge$ & التسوق والتجمعات \\
\hline $1,, \cdot \wedge * * *$ & $1, r r \pm r 0, r q$ & $\vee, r \wedge \pm 19, \wedge r$ & المواصلات والعمل \\
\hline $11, r 7 * * *$ & $r, r \cdot \pm ו r \mid, r$. & $(1,9 \cdot \pm 7 \wedge, 9)$ & اجمالى الوعى بالالتزام \\
\hline
\end{tabular}


ميدانية"، مجلة كلية التربية، مجلد با (، عدد ؟Y، جامعة بنها،

$$
\text { جمهورية مصر العربية. }
$$

حنان عيسى ملكاوي (·.r.r): تداعيات جائحة فيروس كورونا المستجد على الأمن الصحي العربي، نشريه الألكسو العلمية

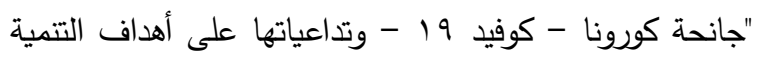

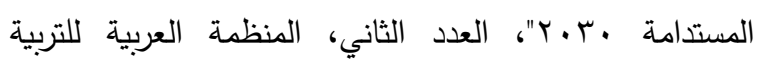
والثقافة والعلوم، جامعة الدول العربية

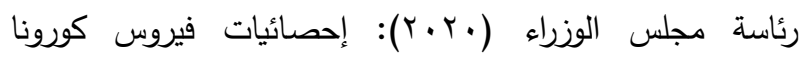

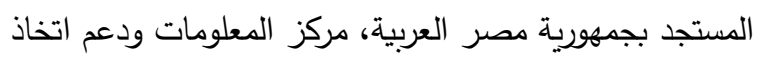

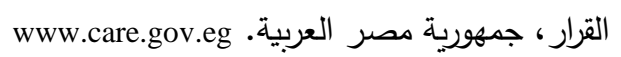

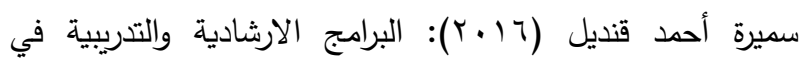
الاقتصاد المنزلي، كلية الزراعة، جامعة الإسكندرية.

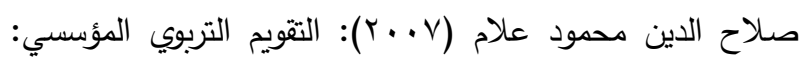

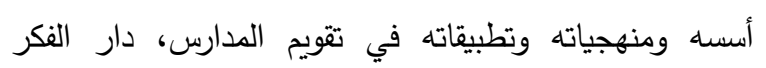
العربي، القاهرة، جمهورية مصر العربية.

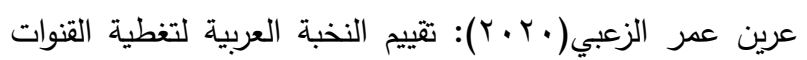
الفضائية الإخبارية لأزمة كورونا العالمية، دراسة ميدانية، مجلة

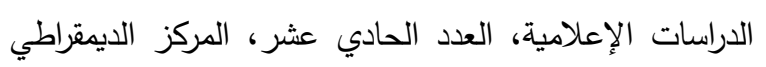
العربي، برلين، ألمانيا.

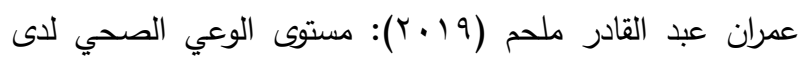

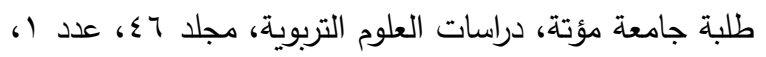

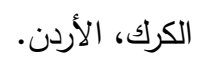
عيشة علة (•r.r): دور وسائل الاعلام الجديد في تنمية الوعي

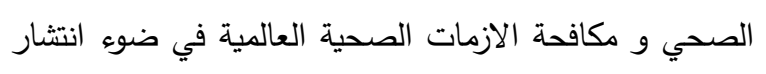
فيروس كورونا (كوفيد -9 1) "دراسة ميدانية"، مجلة الدراسات

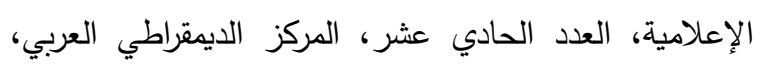
برلين، ألمانيا.

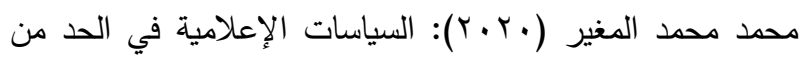

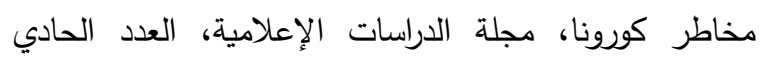

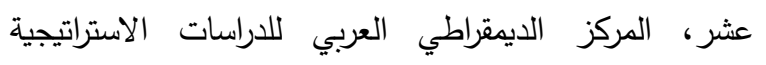
والسياسية والاقتصادية، برلين، ألمانيا.

\section{التوصيات}

1 - إجـراء بـرامج ارشـادية لكافـة فئـات المجتمـع في بيئـات متباينة لنشر الوعي الصـي واتبـاع الاجراءات الوقائية وعدم الاكتفاء بالبرامج التليفزيونية في كيفية التعامل مـع

$$
\text { الفيروس. }
$$

ץ-اعداد برامج في التوعية الصحية لكافة شرائح المجتمع في كيفية التعامل وسُبل الوقاية من الأوبئة المستجدة.

r-استمرار إطلاق حملات صحية توعوية متواصلة لتعديل السلوكيات الخاطئة أثناء وبعد الجائحة.

ع -تفعيل حملات توعويـة عن الفيروس بطريقة تلائم جميع الشرائح بتتسيق مشترك بين وسائل الإعلام ووزارة الصحة

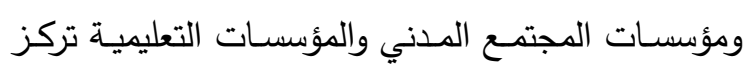
على خطورة المرض ويتم بثها بشكل مستمر على جميع

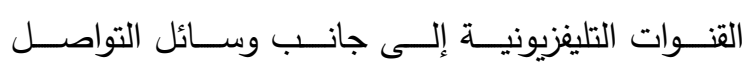

$$
\text { الاجتماعي. }
$$

ه- الاهتمام بتعليق الملصقات وارشادات التوعية في الأماكن

$$
\text { العامة والمدارس والجامعات. }
$$

\section{المراجع}

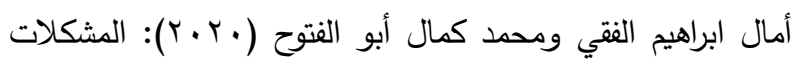

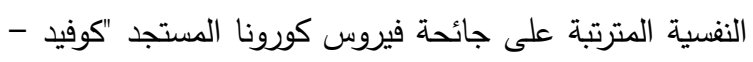
9 1"، بحث وصفي استكثافي لاى عينة من طلاب وطالبات

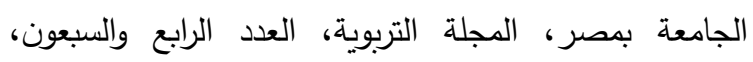
جمهورية مصر العربية.

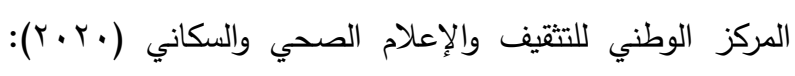
الدليل الارشادي للوقاية من مرض فيروس كورونا (كوفيد -

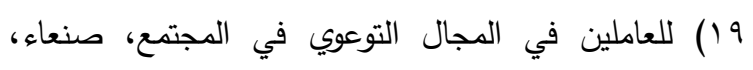

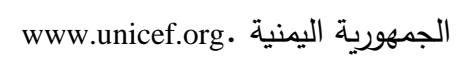
جمال الدين محمد حسن (r . . r): الوعي الصحي لاى طلاب

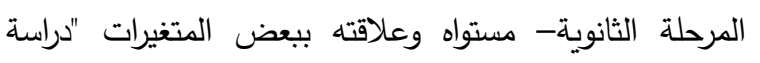




$$
\text { مجلة الإسكندرية للتبادل العلمى - (مجلدrع العدد () يناير - مارس IY.r }
$$

Bangladesh - International Research Journal of Business and Social Science - Vol(6) - No(2). https://ssrn.com

Li,Z;Zhang,Z;Zhong,W;Qisong,W;Wang,Z;Chen,Q;Liu,D;Hu ang,Q;

Shen, D; Chen, P; Mao, A; Zhang, D; Yang, X; Wu, X and Mao, c.(2020): Knowledge, Attitudes, and Practices Related to Coronavirus Disease 2019 During the Outbreak Among Workers in China : Alarge Cross-sectional Study. PLOS Neglected Tropical Diseases- Journal.Pntd https://doi.org.

Papagiannis, D; Malli, F; Raptis, G; Papathanasiou,V; Fradelos, C; Daniil, Z., Rachiotis, G. and Gourgoulianis.I. (2020): Assessment of knowledge, Attitudes, and Practices Towards New Coronavirus(SARS-COV-2) of Health Care Professionals in Greece Before the Outbreak Period Int.J.Environ.Res-PublicHealth.

Paul, A; Sikdar, D; Hossain,M.M;Amin,M.R;Deeba,F. and Mahanta, J. (2020): knowledge and Attitude and Practice Towards Novel Coronavirus Among Bangladeshi People Implications for Mitigation Measures. Medrxiv. 2020. https://doi.org.

Qiu,W; Ruther, F.S. and Chu,C.(2017): The Pandemic and Its Impacts - Health - Culture and Society - Vol (9)- No(10). https:// hcs.pitt.edu.

Retnaningsih,E;Nuryanto,N;Oktarina,R;Komalasari,O; and Maryani,S.(2020): The Effect of knowledge and Attitude Toward Coronavirus Disease- 19 Transmission Prevention practice in South Sumatera Province, Indonesia- Journal of Medical Sciences- Vol(20) - No(8)Research and Development Board of South Sumatera Province- Public Health Education and Training Indonesia. https://doi.org .

Rahman, M; Banik, R; Sikder, T; Rahman, Q.M and Pranta, M.R.(2020): Investigating Knowledge, Attitudes, and practices Related to COVID - 19Outbreak Among Bangladeshi Young Adults: A Web- based Cross-sectional Analysis-Research Square. https://doi.org

Viswanath, A. and Monga, P. (2020): Working Through the COVID-19 outbreak: Rapid Review and Recommendations For Msk and allied health Personnel Journal of clinical or thopaedics and ytrauma.

https://doi.org.

World Health Organization "WHO" (2020): Who Coronavirus Disease (COVID-19) Dashboard https://covid19.who.int .

Zhong, B. L; Luo,W;Zhang, Q.Q; Liu, X.G; Li,W.T and Li, Y. (2020): knowledge,Attitudes and Practices Towards COVID-9 Among Chinese Residents During the Rapid Rise Period of the COVID-19 Outbreak: A Quick Online Cross - sectional Survey - International Journal of Biological Sciences - Vol(16) - No(10). https://doi.org .

$$
\begin{aligned}
& \text { محمد محمد المغير (·. • (Y): حيثيات الفيروس الجديد ومتابعة } \\
& \text { سُبل انتشاره وتحديث الإجراءات والتدابير الوقائية الواجب } \\
& \text { اتباعها للحد من انتشاره وتفشيه في المجتمعات، مجلة } \\
& \text { الدراسات الإعلامية، العدد الحادي عشر، المركز الديمقراطي } \\
& \text { العربي للدراسات الاستراتيجية والسياسية والاقتصادية، برلين، } \\
& \text { ألمانيا. } \\
& \text { مرتضى البثير الأمين وخالا عبد الحفيظ حمد(·. • (Y): وسائل } \\
& \text { التواصل الاجتماعي وتعزيز الوعي الصحي للوقاية من فيروس } \\
& \text { كورونا "صفحة الفيسبوك بالموقع الرسمي لوزارة الصحة } \\
& \text { السودانية نموذجاً" مجلة الدراسات الاعلامية، العدد الحادي } \\
& \text { عشر، المركز الديمقراطي العربي للدراسات الاستراتيجية } \\
& \text { والسياسية والاقتصادية، برلين، ألمانيا. } \\
& \text { مسعودة فلوس والخنساء تومي (·ץ+ץ): الاعلام الجديد يهدد } \\
& \text { الصحة النفسية داخل المجتمعات جراء جائحة فيروس كورونا، } \\
& \text { مجلة الدراسات الإعلامية، العدد الحادي عشر، المركز } \\
& \text { الديمقراطي العربي، برلين، ألمانيا. } \\
& \text { نواره صالح المحارب (r (r): أدوات البحث (الاختبارات), كلية } \\
& \text { العلوم الاجتماعية، جامعة الإمام محمد بن سعود الإسلامية، } \\
& \text { المملكة العربية السعودية. }
\end{aligned}
$$

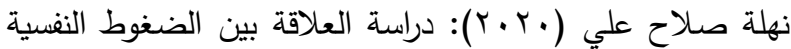

$$
\begin{aligned}
& \text { الناتجة من انتثار فيروس كورونا المستجد (كوفيد - } 9 \text { (1) } \\
& \text { والاضطرابات النفسجمية لدى المرأة العاملة، المجلة المصرية } \\
& \text { للدراسات النفسية، المجلد الثلاثون، العدد (^ • ()، جمهورية } \\
& \text { مصر العربية. }
\end{aligned}
$$

Abdelhafiz, A. S; Mohammed, Z; Ibrahim, M.E; Ziady. H. H; Alorabi, M; Ayyad, M. and Sultan, E. A.(2020): Knowledge, Perceptions, and Attitude of Egyptians Towards the Novel Coronavirus Disease (COVID- 19) Journal of Community Health. https://doi.org .

Eneizan, B; Alhawamdeh, H; Arif, K; Alhamzah A. and Enaizan,O.(2020) : Preventive Practices to Avoid Novel Coronavirus-"COVID-19" at Marketplace during Lockdown in Developing Countries- International Journal of Advanced Science and Technology - Vol(29) - No(5) . https://www.research gate.net .

Farhana,Kh . M; and Mannan, K.A. (2020) : knowledge and Perception towards Novel Coronavirus (COVID- 19) in 


\title{
The Effectiveness of Experiential Program Stemming from Studying Awareness and Following Preventive Measures during the Corona Pandemic, Conducted on A Number Employees at Alexandria University
}

\author{
Enas Mohamed Khamis
}

This research was conducted with the aim of building, implementing and evaluating an indicative program aimed at improving awareness and improving the preventive measures followed by Alexandria University's employees about the emerging Corona Virus. The questionnaire was used in a personal interview to collect data related to this research on a shell sample of (184) employees of Alexandria University, to determine the indicative needs on which the program is based.

The number of experimental sample reached (23) employees of the Faculty of Agriculture - Alexandria University, then the data was statistically analyzed using the Statistical Package for Social Sciences (SPSSV23) and the following statistical transactions were performed:

Percentages, "T" test, Pearson correlation coefficient, "F" test, correlation coefficient, and the results of the study were the following:

- $72.3 \%$ were getting their information from television, and the vast majority of respondents (93.5\%) had good awareness of the preventive measures that should be followed to limit the spread of the disease, and only $53.8 \%$ had good practices regarding following preventive measures to prevent infection with the virus.

- $85.9 \%, 83.7 \%$, and $72.3 \%$ of the respondents said that the exaggeration in the prices of disinfectants and masks and their lack of availability were among the most obstacles they faced during the home ban, and that $58.2 \%$ of the total sample were affected to a severe degree psychologically and socially as a result of staying at home during the ban period.

- The results of the study showed that the females and the married with children sample are more aware of preventive measures.

- There is a moral correlation between the commitment of the sample members to follow the preventive measures and their awareness of these measures.

- The research results showed that individuals with university education and those in professional jobs have higher awareness and commitment to follow preventive measures more than individuals with less educational qualifications and occupying administrative or trades positions.

- The level of good awareness of preventive measures increased by $78.2 \%$ after implementing the program, where it was $34.8 \%$ when the program was implemented. The results also showed that the vast majority of respondents $(82.6 \%)$ had an increased level of overall awareness related to the causes of the spread and symptoms of infection by the virus, and the preventive measures to be followed related to personal hygiene, shopping, gatherings, work environment and transportation, as it was $34.8 \%$ before implementing the program.

- There are statistically significant differences between the pre- and post-application in awareness and commitment to follow preventive measures at a probability level of 0.01 . 